Illinois State University

ISU ReD: Research and eData

Theses and Dissertations

4-2-2019

\title{
The Impact Of Community-Based Training Outreach In Improving Water Quality, Health, And Sanitation In Kenya
}

Lavender Matuyia Ntaoti

Illinois State University, lavenderntaoti@gmail.com

Follow this and additional works at: https://ir.library.illinoisstate.edu/etd

Part of the Communication Commons

\section{Recommended Citation}

Ntaoti, Lavender Matuyia, "The Impact Of Community-Based Training Outreach In Improving Water Quality, Health, And Sanitation In Kenya" (2019). Theses and Dissertations. 1093.

https://ir.library.illinoisstate.edu/etd/1093

This Thesis is brought to you for free and open access by ISU ReD: Research and eData. It has been accepted for inclusion in Theses and Dissertations by an authorized administrator of ISU ReD: Research and eData. For more information, please contact ISUReD@ilstu.edu. 


\title{
THE IMPACT OF COMMUNITY-BASED TRAINING OUTREACH IN IMPROVING
}

\author{
WATER QUALITY, HEALTH, AND SANITATION IN KENYA
}

\section{LAVENDER MATUYIA NTAOTI}

\section{Pages}

Water is an important component of the human body. A greater percentage of the body comprises of water. Digestion, brain function, movement, and sweating among others are the basic functions of the human body that require water. Often, water quality is neglected in developing countries such as Kenya, Uganda, and Tanzania. Many individuals in these countries understand the importance of having accessible water but do not prioritize the quality and the sources of the water available to them. Public health scholars endorse education, training, and sanitary infrastructure to promote awareness and importance of water quality. To address an existing waterborne disease crisis in a school in Kenya, the researcher conducted a needs assessment and tested the applicability and modified a water purification technology (WaterPOD) along Menomonee River in WI. Upon success of the simulation, the researcher used the Health Belief Model, Diffusion of Innovations, and Assessment, Design, Implementation, and Evaluation model (ADDIE) of instructional design to develop a water health-training program, which she later implemented and evaluated in 5 locations in Kenya. The results showed that the training program increased public awareness, perceived severity of waterborne diseases; water treatment and source protection. It also increased self-efficacy on household water health and sanitation. 
KEYWORDS: Public Health; WaterPOD; Training; Self-efficacy; Water quality;

Contamination; Water treatment; Waterborne diseases; HBM; DOI; ADDIE 
THE IMPACT OF COMMUNITY-BASED TRAINING OUTREACH IN IMPROVING WATER QUALITY, HEALTH, AND SANITATION IN KENYA

LAVENDER MATUYIA NTAOTI

A Thesis Submitted in Partial Fulfillment of the Requirements for the Degree of

MASTER OF SCIENCE

School of Communication

ILLINOIS STATE UNIVERSITY

2019 
(C) 2019 Lavender Matuyia Ntaoti 
THE IMPACT OF COMMUNITY-BASED TRAINING OUTREACH IN IMPROVING WATER QUALITY, HEALTH, AND SANITATION IN KENYA

LAVENDER MATUYIA NTAOTI

COMMITTEE MEMBERS:

John R Baldwin, Chair

Lindsey Thomas

Lance Lippert 


\section{ACKNOWLEDGMENTS}

All the glory to the almighty God for his unending love, favor, and grace upon me. This achievement could not have been possible without the support of Vic Hamer, Erica and Paul Mollet, Jayne and John Cross, Gary and Roberta Gordon, Mellanie and Bill Portz, Kathy and Kylie Liefer, Bill Hamer, Loren Priest, and the Buhlers for all the prayers and support.

I wish to express my most heartfelt gratitude to my ever-supportive academic advisor, role model, and Thesis Chair Dr. John Baldwin for creating time out of your busy schedule to add value to this thesis throughout the project duration and my time in graduate school. Thank you, Dr. Lance Lippert and Dr. Lindsey Thomas for being part of my committee. Dr. Kevin Meyer, I appreciate your help and dedication during the admission process despite our time difference and of course for letting me show up at your office without appointments.

Thank you, Stonehouse Water Technologies, for giving me the internship opportunity that opened numerous doors for me and my country. Hensley Foster, thank you for every opportunity you have given me to prove and better myself. To Dr. Moe, thank you for reviewing my technical chapters and for letting me use your product for my research.

Thank you, Dennis Tolle, for being my wonderful research assistant. Thank you, Rev. Henry Kopirato, and Loiso for organizing and recruiting participants for the training program. Not to forget my wonderful chit-chat friends and colleagues Kate Rybakova, Erica, Maame, Desi, Dawn, Shanna, Mbengei, M. Juma, Michelle, Misia, Nikki, and Kerri, thank you for your encouragement and making my day brighter every day.

I dedicate this thesis to my mom for being the greatest wonder woman of all times. I celebrate you today and forever for loving and single-handily supporting me and my siblings to this far. Thank you for making sure I slept comfortably each night dreaming about all the good 
things in life, which you never had. To my late dad, I know you are so proud of the little babies you left with the greatest mom, thank you for the beautiful memories and for watching over us every day. Thank you, my super-sister Immaculate for believing in me and giving me more than I deserve. Shane, Deloris, Alisa, Jane, Duncan, Jonathan, and the entire family this is our success, thanks for the love.

I also dedicate this thesis to my guardian angel, Vic Hamer. Thank you for the many sacrifices you made/ are making to ensure I am successful, feeling loved, and supported. Since you came into the Ntaoti family you have been a blessing to us and a great father figure to me. Thank you for the wonderful things you do for the people that Give Me Water Lord serves.

To my 'adopted' Grandma Opal Williams, thank you for funding my education in honor of your late husband and daughter, this thesis commemorates them. Blessings to you Carol McKeena for your support as well.

This thesis was sponsored by Give Me Water Lord (GMWL), which is a non-profit organization based in the Sparta Illinois, United States of America. Vic Hamer founded GMWL in 2012. Its vision and mission is to bring safe drinking water to water scarce areas in Kenya. To empower and promote economic development of humble families and orphans living in Kenya, the organization initiates other projects besides drilling wells. These projects include the cow project, feeding programs, and sponsorship. 


\section{CONTENTS}

Page

ACKNOWLEDGMENTS

TABLES viii

FIGURES

CHAPTER I: BACKGROUND OF THE STUDY 1

Community Engagement and Water Health Promotion 3

$\begin{array}{ll}\text { The Current Study } & 4\end{array}$

$\begin{array}{ll}\text { Conclusion } & 5\end{array}$

$\begin{array}{ll}\text { CHAPTER II: LITERATURE REVIEW } & 7\end{array}$

$\begin{array}{ll}\text { The Importance of Water } & 7\end{array}$

Water Sources, Quality, and Impact on Health $\quad 8$

Health Impacts of Surface and Groundwater Contamination $\quad 11$

Standards for Drinking Water Regulations Globally and Locally 12

$\begin{array}{ll}\text { Emerging Contaminants with no Solutions } & 15\end{array}$

Commercially Available Water Treatment Systems 15

Large Public Water Treatment Systems $\quad 15$

$\begin{array}{ll}\text { Point-of-Use Water Treatment (POU) } & 18\end{array}$

Safe Water Storage: Modified Clay Pot 21

Point-of-Entry Water Treatment 21

$\begin{array}{ll}\text { The WaterPOD } & \\ & \end{array}$

Simulating the Applicability of the WaterPOD Technology to Third World Countries 26

The Point of Grace Academy Project in Kisumu, Kenya 26 
Menomonee River Pilot Project (MRP)

$\begin{array}{ll}\text { Conclusion } & 30\end{array}$

CHAPTER III: WATER HEALTH COMMUNICATION 31

Health Literacy and Communication $\quad 31$

$\begin{array}{ll}\text { Education and Training } & 32\end{array}$

$\begin{array}{ll}\text { Training and Self-Efficacy } & 33\end{array}$

$\begin{array}{ll}\text { Theoretic Framework } & 35\end{array}$

Health Belief Model $\quad 35$

Health Belief Model and Water Health $\quad 38$

Diffusion of Innovations Model $\quad 41$

$\begin{array}{lr}\text { Conclusion } & 47\end{array}$

CHAPTER IV: INSTRUCTIONAL DESIGN 48

$\begin{array}{ll}\text { Learning and Instructional Design Technology } & 48\end{array}$

$\begin{array}{ll}\text { ADDIE Model } & 49\end{array}$

Water Health Training in Kenya $\quad 51$

$\begin{array}{ll}\text { Program Needs Analysis } & 52\end{array}$

$\begin{array}{ll}\text { Operational Competency } & 52\end{array}$

$\begin{array}{ll}\text { Self-Efficacy } & 53\end{array}$

Knowledge on Waterborne Illnesses $\quad 54$

$\begin{array}{ll}\text { Participants' Profile } & 54\end{array}$

$\begin{array}{ll}\text { Training Objectives } & 54\end{array}$

$\begin{array}{ll}\text { Program Design } & 55\end{array}$

$\begin{array}{ll}\text { Program Development } & 57\end{array}$ 
Actual Program Implementation

Samuli

Nairobi

Kisumu

Program Evaluation

Participants Profile

Procedure

Measures

Time 1 Survey

Time 2 Survey

Data Analysis

Results

Perceived Benefits

Themes on Important Lessons learned from the Training

Water Quality

Water Treatment Procedures and Methods

WaterPOD in Water Treatment 
$\begin{array}{ll}\text { Susceptibility } & 78\end{array}$

$\begin{array}{ll}\text { Self-Efficacy } & 79\end{array}$

$\begin{array}{ll}\text { Observation Results } & 80\end{array}$

$\begin{array}{ll}\text { Hands-on Work } & 80\end{array}$

Technical University of Kenya Post-training Discussion $\quad 80$

$\begin{array}{ll}\text { Conclusion } & 81\end{array}$

CHAPTER VI: DISCUSIONS/ RECOMMENDATIONS 82

Contributors of Program Success $\quad 82$

$\begin{array}{ll}\text { Setting Up } & 82\end{array}$

Introduce 'Preparation' into ADDIE (ADDPIE) 82

$\begin{array}{ll}\text { Multitasking } & 83\end{array}$

$\begin{array}{ll}\text { Interacting with Participants } & 84\end{array}$

Theoretical Implications on the Program's Success 85

Health Belief Model $\quad 85$

Diffusion of Innovations Theory $\quad 85$

Intersection of HBM and DOI in Training $\quad 87$

Trainer's Contribution to the Training Success $\quad 88$

Findings/Training Transfer $\quad 89$

$\begin{array}{ll}\text { Future Program's Changes } & 89\end{array}$

$\begin{array}{ll}\text { Pictures and Graphics } & 90\end{array}$

$\begin{array}{ll}\text { Time for Training and Interaction } & 90\end{array}$

$\begin{array}{ll}\text { Conclusion } & 90\end{array}$

$\begin{array}{ll}\text { REFERENCES } & 92\end{array}$ 


\section{TABLES}

Table

Page

1. Menomonee River Pilot Project Contaminants Cause and Their Possible Health Concerns

2. Proposed Program General Schedule

3. Training Kisumu Program Schedule

4. Training Program Samuli Schedule

5. Training Program Oltinka Schedule

6. Training Program Nairobi Schedule

7. Training Program Kisumu Schedule

8. Perceived Training Benefits 


\section{FIGURES}

Figure

1. The percentage of water in the human body in different stages of life 8

2. Public Water Treatment Systems steps 16

3. The WaterPOD 23

4. The 8 stages of the WaterPOD 24

5. Point of Grace Academy about 700+ children in need of clean water 26

6. Best filter combination for a highly contaminated water source, which treated 3636 gallons in 12.5 hours $\quad 30$

7. Application of HBM on water health 39

8. Map of Kenya showing training locations 62 


\section{CHAPTER I: BACKGROUND OF THE STUDY}

Public health is the science and practice of protecting and improving the health of the community by preventive medicine, health education and promotion, controlling communicable diseases, enforcing of sanitary measures, and monitoring of environmental threats to individuals' health. The public health system has sectors that assist in promoting and protect people's general health, for example, water health. Water contamination is a section of public health that requires special attention due to its negative impact on public health. Some of the many ways in which the public health sector can promote water health are by assessing patterns of waterborne diseases, investigating water sources, providing vital information, supporting new water quality standards, and involving the community to promote drinking water quality. Municipalities and other water management groups can also prepare for response to contamination occurrences and identification of unregulated contaminants.

Safe and readily available water is important for public health regardless of its usage. For example, drinking, domestic use, food production, or recreational purposes. Improved water supply, sanitation, and management of water resources can boost economic growth. In 2010, the United Nations General Assembly explicitly recognized the fact that everyone has the right to sufficient, continuous, safe or acceptable, physically accessible, and affordable water for personal and domestic use. Despite the UN resolution, access to safe drinking water and sanitation has not improved as most reputable governmental and non-governmental organizations have noted:

- Yearly, about 443 million school days are lost due to water-related illnesses (Human Development Report, 2006)

- In 2015, 2.1 billion people consumed unsafe water (WHO, 2015) 
- $31 \%$ of schools do not have clean water (UNICEF, Advancing WASH in Schools Monitoring, 2015)

- A newborn baby dies every minute from infection caused unsafe water and unclean environment (WHO, 2015)

- 844 million people have no access to clean water (Joint Monitoring Programme, 2017)

- 2.3 billion people do not have a decent toilet (WHO/UNICEF Joint Monitoring Programme (JMP) Report 2017) and that affects their general water health

- Diarrhea caused by dirty water and poor toilets kills a child under 5 years of age every 2 minutes (WASHWatch.org)

- The World Bank note that promoting good hygiene is one of the most cost-effective health interventions to diseases (Disease Control Priorities, 2016)

- If each individual worldwide had clean water, the number of diarrheal deaths could reduce by a third (Tropical Medicine \& International Health, 2014).

Improving the quality of drinking water can prevent or reduces a tenth of the global public health burden. Encouraging individual and community hygiene practices to improve the health of all populations despite their status and available resources results adequate sanitation (WHO, 2008, 2014). Efforts to provide access to safe drinking water have been impotent and remain a topic of discussion in various nations (WHO, 2014).

In Sub-Saharan Africa, unsafe drinking water is one of the most critical health issue, which has over the years increased the world disease burden in developed, developing, and third world countries. In fact, more people die due to consumption of polluted water than those who die in violence or wars across the world (UN, 2014). Water health, issues coupled with shortage of healthcare workers, is becoming a pressing and complex challenge in Africa. It becomes a 
multifaceted crisis caused by socio-political and environmental issues at both national and international levels weakening the quality of life. However, a shortage of data has hampered education efforts due to lack of useable databases on public health training, consequently, providing little information on public health education and training and demonstrating a low understanding of factors that affect the public awareness of drinking water quality, which contributes to poor water management, prevention, and control of waterborne diseases.

Water sources, treatment processes, and supplies influence water safety and quality. Better management of water resources helps prevent waterborne diseases. Pathogenic microorganisms present in contaminated fresh water transmit waterborne diseases such as malaria. Municipalities and health educators argue that providing safe drinking water is not enough to reduce or eradicate water borne diseases. For example, Doria, (2010) and Wright, Yang, Rivett, and Gundry (2012) endorse that public engagement is an important notion of water management. Further, Water sources and quality awareness influence water health public engagement activities (Hoedjes, 2014; Wang, Zhang, Lv, Zhang, \& Ye, 2018).

\section{Community Engagement and Water Health Promotion}

Health promotion is the process of empowering individuals to develop or increase control over their health to reach to an overall wellbeing state to be able to identify and satisfy their needs and goals and to cope with the changing environment (Kumar \& Preetha, 2012). Mostly, cultures use health promotion as a strategy to encourage water health across cultures. Therefore, for the purpose of this study, the researcher defines water health promotion as the art of empowering individuals through organized community training to be able to identify the importance of water health, use water purifications systems, observe sanitation, and protect water sources to prevent water-related disease. It facilitates the communication of information that 
enables people to make informed decisions and to shun habits that increases their susceptibility to ill-health related diseases, such as hygiene and effective water purification (Ferron, Morgan, \& O'reilly, 2000).

Communities have embraced health messages and education provided by health workers during water health trainings. Denno, Hoopes, and Chandra-Mouli (2015) attribute this to communities recognizing their own workers and, therefore, this enhances health workers' active role with their audience without any distrust or language barrier (De Rochars et al., 2011). The consistency of the health messages reflects the intensity of training and the effectiveness of the information received by the communities. The knowledge of waterborne diseases symptoms, prevention, treatment, and modes of transmission indicated that public health messages had been effective. The messages are effective in promoting behavior changes for example drinking chlorinated water, to address the threat of waterborne diseases.

Free water treatment systems or products such as chlorine and Aquatab tablets have been uses as emergency response to waterborne diseases (Patrick, Berendes, Murphy, Bertrand, Husain, \& Handzel, 2013). Rural areas have a high reception of these products due to availability and ease to use during water treatment. On the flip side, studies have note negative health effects caused by the product (Crider et al., 2018; Zyara, Torvinen, Veijalainen, \& Heinonen-Tanski, 2016). More research should provide accurate information on different water purifications systems as well as education and training to ensure that water treatments are efficiently and effectively use.

\section{The Current Study}

In efforts to provide water treatment solution to a school in Kenya, the researcher conducted research on water purification filters along Menomonee River, WI. Upon the success 
of the project, the researcher developed a training program. This training program was designed specifically to create awareness on water health and use of purification technologies in developing countries. This program targeted the public because of the role that each individual contributes to water quality, source contamination, and sanitation, and general water health. The study focuses on increasing individuals' self- efficacy, water purification operation efficacy, and susceptibility to waterborne diseases.

The study uses tenets of Health Belief Theory and Diffusion of Innovations to guide selection of participants, content, and interaction with the participants. Using the five steps of Assessment Design Development Implementation Evaluation model (ADDIE) of instructional design, the researcher designed the training program. The program goal was to provide a platform for exchange of experiences, strengthen existing water health initiatives, and identify and disseminate good water health practices such as water treatment and sanitation. Other goals included advocacy and transfer of knowledge on the use of water purification (WaterPOD), which is an on-demand water purification system. The researcher, thereafter, implemented the program in four locations in Kenya: Samuli, Oltinka, Nairobi, and Kisumu.

\section{Conclusion}

This chapter presents an overview of water health and community-based approaches to improving public health. It is clear that water quality is an important aspect of public health. In addition, interventions such as education, training, and sanitary infrastructure result to increase in a nation's economic development. These mentioned interventions facilitate identification of water sources and processes that are fit for human consumption to minimize the cases of waterborne diseases. The findings of this study provide more insight on community engagement (training) interventions and processes that contributes to learning and development, health 
communication and water science disciplines. The next chapter introduces a detailed explanation of supporting scholarly evidence on importance of water quality and source protection. 


\section{CHAPTER II: LITERATURE REVIEW}

There are two main sources of water: surface water and groundwater. Lakes, rivers, and reservoirs are the common sources of surface water. Groundwater lies under the surface of the land, where it travels through and fills openings in the rocks. This chapter explores the different types of water and the socio-economic problems that communities living in developing and third world countries face on their quest for safe drinking water. Further, the chapter explores global water quality, information storage technologies, and laws that regulate the different types of water. Further, this chapter shows various sources of water contamination, drinking water treatment methods, and their limitations. Finally, it introduces the Menomonee river project and WaterPOD water purification technology, which is partly the focus of this study.

\section{The Importance of Water}

Water quality is the physical, chemical, biological, and radiological properties of water. Water comprises of tiny molecules of hydrogen and oxygen. The molecules are visible neither with the naked eyes nor with a powerful microscope. Water exists in three different forms: liquid (found in lakes, clouds or rain, mist, rocks, fog, dew), solid (ice, snow, frost), and gaseous (vapor and the invisible water in the air). Pure water is colorless and odorless. Water carries essential minerals that are important for the human body's organisms, flushing out toxicity from the digestive tract, lubricating the joints, and cooling the body after vigorous activities (ClassenBauer, 1993). However, factories use water to manufacture products such as food, in medicines, in hospital sanitation, and on farms to grow crops. 


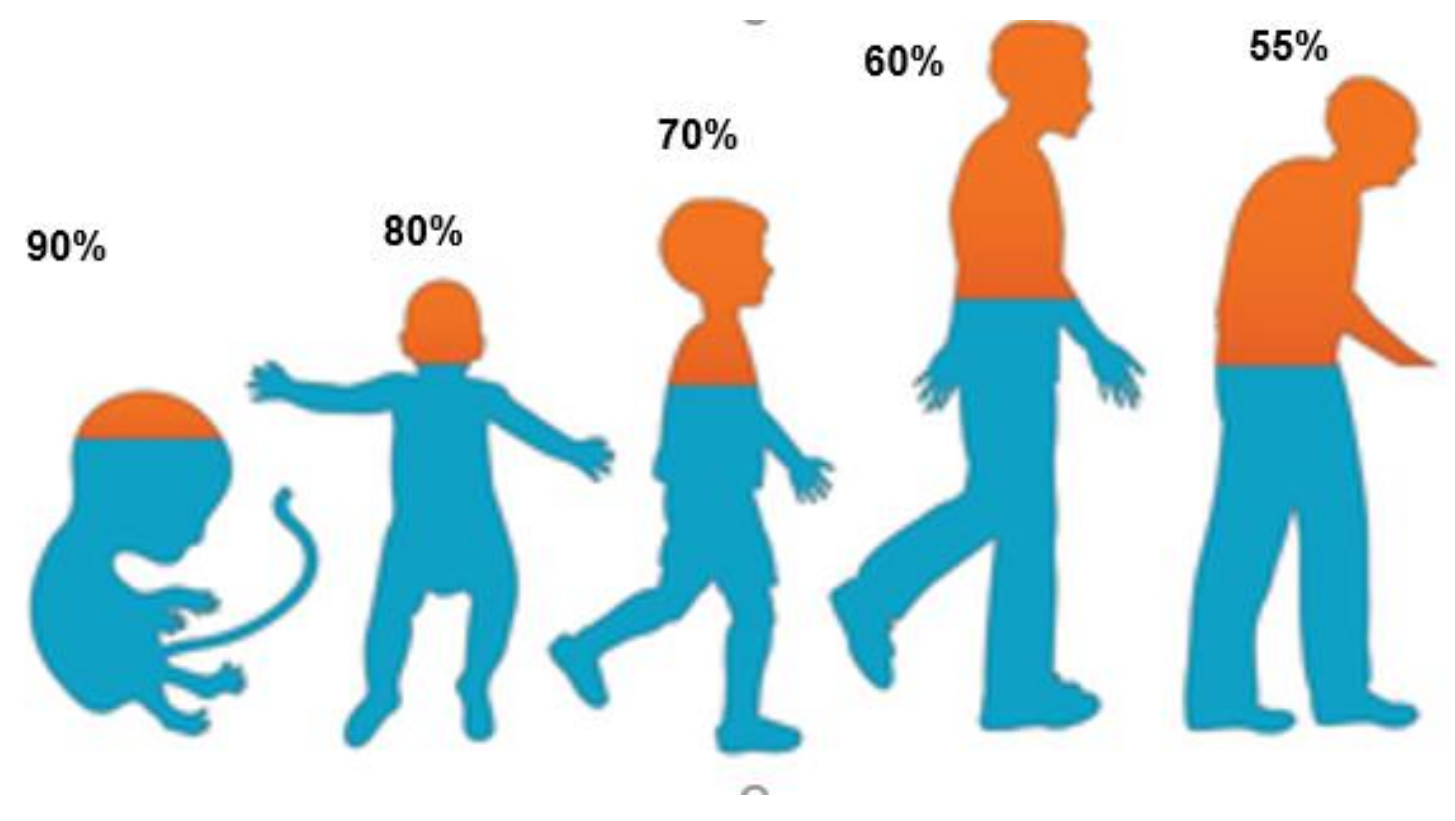

Source: Alvogenors.

Figure 1. The percentage of water in the human body in different stages of life.

Approximately, $90 \%$ of an unborn baby's body is water; the figure is $80 \%$ for a toddler, $70 \%$ for a child, $60 \%$ for an adult, and 55\% of an elderly human body as shown in figure 1 . These statistics show that a large percentage of the human body is water, and, therefore, drinking water should be safe and free from any sort of disease-causing organisms and contaminants. The World Health Organization (WHO) recommends an average of 6 to 8 glasses of safe water for individuals every day (WHO, 2004). Athletes and individuals with illnesses are encouraged to drink more water compared to non-athletes and those with illnesses. When these recommended guidelines are not followed, negative health conditions such as dehydration and constipation occur (Grandjean, 2004).

\section{Water Sources, Quality, and Impact on Health}

Even though water is an important constituent, as described above, safe drinking water is yet to be defined; rather, different organizations, individuals, and countries define what constitutes safe drinking water. The World Health Organization (WHO), being the most 
significant international health organization, recommends guidelines that safe drinking water should meet (World Health Organization, 2004). The following section describes the water sources and issues associated with each source.

Surface water. Considering the fast-growing population and farming activities worldwide, sources available to provide safe drinking water are becoming increasingly scarce. Most surface water sources are polluted with all sorts of contaminants, including leaching of corroded pipe materials that are over 200 years old. These aged pipes carry water from fresh water sources and storage facilities to our homes. Old pipes are not the only cause of surface water pollution. In agricultural areas, pesticides and leachate are swept off by rainwater from farmland to drinking water sources (Dabrowski, 2015). Many municipal water plants were not designed to remove such toxins. De Jager et al. (2011) note that the spray drift from livestock shed and fields is popular in many agricultural areas such as Kenya and South Africa. Exposure to pesticides has been linked to malaria vector control and injuries leading to high cost of treatment (Quin, Balfors, \& Kjellén, 2011).

In over $90 \%$ of developing countries, the quantity of untreated wastewater discharged into water bodies is striking. Connor (2017) notes that $90 \%$ of untreated wastewater in Kenya and Ghana, is intentionally released into lakes and oceans. Van, Biggs, Smout and Drechsel (2009) state that more often this contamination poses a threat to marine life by exposing it to toxic substances that may lead to death, consequently, affecting the food chain, fisheries, and livelihood of individuals who consume seafood. In addition, dumping wastewater into rivers, lakes, and oceans leads to low oxygen levels in source water (deoxygenation), causing the death of marine life and having a negative impact on the economy. Turley et al. (2016) reveal that 
deoxygenated areas in Africa's water bodies are rapidly increasing across the developing countries.

Major, Omojola, Dettinger, Hanson, and Sanchez-Rodriguez (2011) link wastewater with climate change or global warming. Their study concluded that wastewater produces methane and nitrous oxide, which are the most powerful global warming-causing gases. Climate change affects water resources and increases individuals' vulnerability to water contaminants that can cause diseases. For example, elevated climatic conditions promote pathogens such as bacteria, viruses, and other illnesses caused by algae, toxins, and chemicals released to the environment. Similarly, harmful contaminants can be inhaled or ingested through consumption of fish or food exposed to the polluted water. For example, in many developing countries, such scenarios trigger human exodus (Tosam \& Mbih, 2015), such as the recent emigration of Syrian refugees. Therefore, any kind of water pollution directly or indirectly affects all living things.

Ground water. Ground water is perceived as the most reliable source of clean water to the majority of the populations living in rural areas in Africa. It is the cleanest since it is naturally protected from bacterial contaminants, and it is reliable during drought seasons. However, according to Faust and Aly (2018) and Kayembe et al. (2018), ground water is not entirely safe either. When the local bedrock formation has arsenic, lead, copper, or other toxic elements, the same constituents are present in the ground water; when the soil formation is porous, leaking pipes and poor sanitation contaminate the groundwater sources and, hence, impact the health of those consuming it. Unlike surface water, which is tested frequently, in most cases, ground water is not tested, and, therefore, there is a need to monitor and treat groundwater before drinking or using it in households (Awuah, Nyarko, Owusu, \& Osei-Bonsu, 2009). 
There is a high cost associated with identifying clean water sources that may provide adequate water for communities living in rural areas. Many communities, especially those in Africa are forced to use water from polluted communal water points.

Other non-point sources of surface and groundwater contamination. According to the European Chemical Agency (2010), European countries export chemicals that pose risk to individuals' health. Flynn (2015) notes that some chemicals that are found in Africa's water sources have been banned in European countries and are imported to Africa for use. These chemicals find their way to Africa's water sources through crop irrigation, resulting in unhealthy food production, for example, salad crops (De Bruin et al., 2017) and cooked food (Singh et al., 2007). Therefore, the water quality used in irrigation affects the quality of the food consumed regardless of the way in which it is prepared before consumption. For example, a study found traces of the chemical contaminants such as dioxins in chicken eggs and domestic grown vegetables (Bouwman et al., 2015).

\section{Health Impacts of Surface and Groundwater Contamination}

Given the above scenario, it is therefore, not surprising that sources contamination investigations have linked unsafe drinking water to child mortality, morbidity, and mortality among young children. Specifically, studies reveal that the children who drink or use polluted water die from dehydration caused by dysentery and bathing in contaminated water (Metwally, Ibrahim, Saad, \& El-Ela, 2006) and malnutrition. Saade, Bateman, and Bendahmane (2001) indicate diarrheal diseases as one of the leading causes of morbidity and mortality among young children in Africa. These health conditions can be avoided by drinking clean, safe water. In the same vein, studies found that water has a direct effect on sanitation. For example, Macassa, Ghilagaber, Bernhardt, and Burstrom (2004) indicate that children who live in households 
without plumbing water and toilet facilities have a greater chance of dying due to poor hygiene compared to those with plumbing and a proper toilet.

Investigations elsewhere have even linked gender violence with quest for clean water in African countries. In most African traditions, it is a woman's responsibility to provide water for her family. Often, women are forced to walk miles to get clean water for their families. Women walk many hours looking for clean water, increasing the chances of sexual assault, as young women reported sexual violence, torture, shaming, and harassment from boys and men. This has resulted in early pregnancies among young girls (Dankelman, 2010; Gonsalves, Kaplan, \& Paltiel, 2015). Mental health issues and death also occur among African women. Moreover, searching for water inhibits women from having time for education, being with their families, and earning a living for themselves, thus, there is a need to treat accessible water to prevent violence against women.

\section{Standards for Drinking Water Regulations Globally and Locally}

Water contamination problems discussed above are not only prevalent in $95 \%$ of developing countries but also in many developed nations, such as the U.S.A and Europe. The World Health Organization (WHO) is an agency of the United Nations that sets guidelines for safe drinking water. These guidelines are voluntarily adopted by most developing countries, but some countries such as Kenya and Indonesia do not enforce them due to inadequate resources. In fact, the public is not aware of these rules. For some developing countries, such policies do not exist.

In the U.S, the Environmental Protection Agency (EPA) regulates municipal water systems. The EPA offers information on water testing and water treatment technologies for private wells. However, it neither regulates nor provides criteria or guidelines for private wells 
(EPA, 2017). It is up to the counties, cities, and well owners to ensure that private well owners adhere to the policies that facilitate clean drinking water for residents to protect their health. Unfortunately, many of these local policies are merely advisory and non-enforceable across the States, thus, frequently, many well owners do not pay attention to these policies.

In 2016, the Environmental Health Collaborative Summit (as cited in Gibson, \& Pieper, 2017), highlighted barriers that hinder individuals' adherence to private well water quality testing and treatment policies. First, there is a lack of a comprehensive database of well locations. This means that the wells are not accessible for inspection, posing a health risk to those consuming the water from those wells. Hoppe, Harding, Staab, and Counter (2011) found that the list of registered private owners in their database is incomplete and owners cannot be located. Some private well registration is done on paper and, in some cases, not digitally entered into the system correctly. Moreover, old wells are not included in the database. This leads to lack of monitoring and maintenance of old wells, which, when used by individuals, increase their exposure to water-borne diseases and possibly death. To counter the problem, Backer and Tosta (2011) started an initiative to find the unregulated drinking water well locations in the U.S. Apparently, the campaign has not been successful per se, as many wells are still not registered (Gibson \& Pieper, 2017), leading to a lack of water quality monitoring.

Some private well owners are not compliant with the recommendations provided by the Environmental Protection Agency for monitoring and maintenance of their wells. Schwartz et al. (1998) and Boyer, Swistock, Clark, Madden, and Rizzo (2012) noted that a large percentage of private well owners have never tested their water. Other private owners reported lack of information on where to send their water samples for testing (Knobeloch, 2009). Other researchers have associated poor water quality testing with lack of education among the 
populations utilizing the wells and their attitudes in believing that water from wells is safe for domestic usage. Awuah, Nyarko, Owusu, and Osei-Bonsu (2009) disclose that, when wells are built, the quantity of water becomes of importance to people more than the quality of the water they are getting. Furthermore, the findings of Awuah and colleagues also show misconceptions that well owners have regarding water testing. For example, some believe that the human sensory systems can detect contaminants; therefore, in their opinion, laboratory water testing is not required. This misconception leads to consumption of polluted water, increasing individuals' vulnerability to diseases such as dysentery and cancer. In addition, racial disparities exist where communities such as the Black community have been denied municipal services, and the neighborhoods have been excluded from municipal services (Aiken, 1987; Durst, 2014; Ranganathan \& Balazs, 2015).

In another study, well owners cited financial reasons as one of the factors inhibiting frequent well water testing as required by safe drinking water guidelines (Borsuk, Rardin, Paul, \& Hampton, 2014), while in some parts of U.S, 65\% of private owners reported testing their water, and $24 \%$ stated conducting water testing during the last year. On the same note, there are not good policies or water quality testing programs that support well owners, and wells are not regulated in some states and countries such as Kenya (Boyer, Swistock, Clark, Madden, \& Rizzo, 2012). There are no policies put in place to regulate reselling of water from wells. Fox, Nachman, Anderson, Lam, and Resnick (2016) describe a good policy for resale of well water as one that requires water sellers to conduct testing before selling and reselling the water to the public due to poor storage facilities. 


\section{Emerging Contaminants with no Solutions}

Emerging evidence shows that pharmaceuticals are the new emerging water contaminants in Africa. A researcher conducted water sample testing in five municipal water treatment plants and reveal the presence of personal care products and endocrine active drugs (Patterton, 2013). On the other hand, Osunmakindeet et al. (as cited in Archer, Wolfaardt, \& van Wyk, 2017) proposed ways in which pharmaceuticals can be identified and removed from the water at a personal level, such as water purification systems in homes and other health care products used to treat wastewater. The following section introduces commercially available technologies to treat water for human consumption.

\section{Commercially Available Water Treatment Systems}

There are three categories of commercially available drinking water treatment system. These include large decentralized systems, Point of Entry (POE) and Point of Use (POU) systems. Each of these categories are discussed below.

\section{Large Public Water Treatment Systems}

A Public Water Treatment System (PWTS) refers to any water system with at least 15 connections to homes and businesses. Water treatment systems with less than 15 connections are private water systems (PWTS). Therefore, PWTS can serve cities and towns. There are two types of PWTS. They include drinking water and wastewater systems. Regardless of the responsible body or ownership of PWTS, all the systems must comply with all guidelines for safe drinking water. This report only focuses on drinking water PWTS. Figure 2 shows a diagram of a typical drinking water PWTS installed in Lake Victoria. Figure 2 also illustrates the steps followed in a PWTS. 


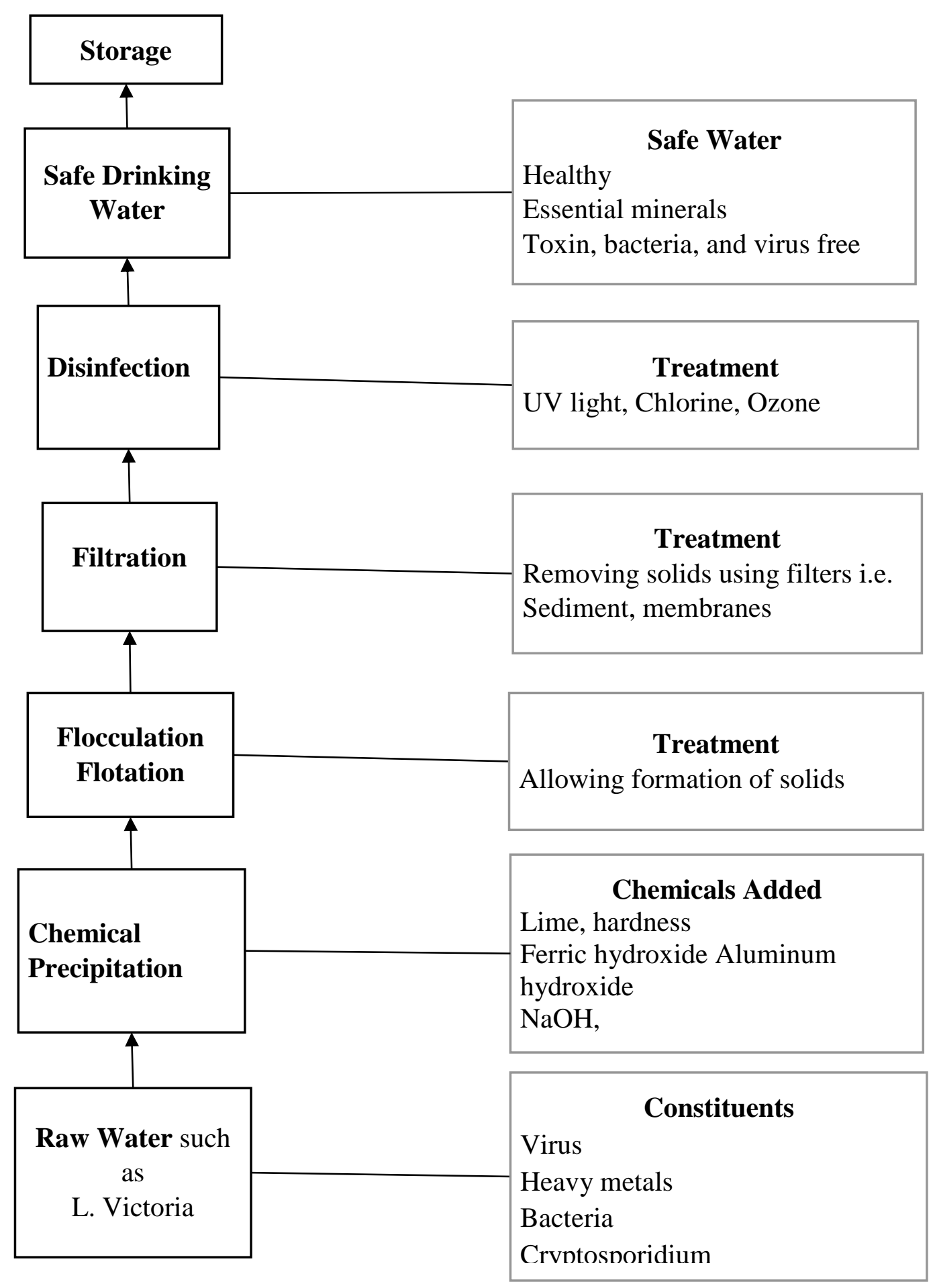

Figure 2. Public Water Treatment Systems steps.

The next page presents a brief description of PWTS. 
Step 1: Raw water. Raw water is any water consumed directly from the source without any treatment. Raw water contains different kinds of contaminants, including lead, arsenic, thallium, chromium, mercury, and microorganisms that cause illnesses. At the plant, it is stored in tanks then delivered from Water Plant to homes through pumps and pipes.

Step 2: Chemical precipitation. In this stage, chemicals such as sodium hydroxide, calcium hydroxide, aluminum hydroxide, and ferric hydroxide are added to the water. The chemicals are added depending on the water quality or contaminants present in it. For example, if the raw water in L. Victoria is hard, lime can be added to soften the water at this point, or ferric hydroxide and aluminum hydroxide to remove heavy metals from the water, sodium hydroxide, and calcium hydroxide. These chemicals combine to form sticky solid particles, called floc, that attract any dirt present in the water.

Step 3: Flocculation. Due to the weight of the flocs and dirt particles, the flocs sink to the bottom of the tank. The floc and dirt are allowed to settle at the bottom of the tank, and the clear water is pumped to the next stage, which is filtration.

Step 4: Filtration. The water is pumped through filters of different micron-sizes to remove fine sand particles found in the water. Examples of these filters are sediment filters and membranes, which have a medium that traps the floc while clean water flows through.

Step 5: Disinfection. At this stage, water is treated to kill disease-causing organisms such as viruses, bacteria, and protozoa. Water treatment plants mainly use three methods of disinfection. The use of chlorine disinfection to disinfect municipal water is common across cities and towns because of its ability to kill disease-causing organisms. Chlorine is manufactured and supplied in various forms, for example, solid, liquid, and gaseous form, therefore, providing a flexible dosage control, which is cost effective. Moreover, chlorine 
remains that are left after the water treatment result in the prolonged disinfection. On the other hand, the residue of chlorine systems can be toxic to aquatic life (Mitch \& Sedlak, 2002).

Studies show that chlorine reacts with naturally occurring organic matter found in surface and ground water to form toxic byproducts that are highly regulated because they are known to cause cancer (Rule, Ebbett, \& Vikesland, 2005; Sumpter, Johnson, Williams, Kortenkamp, \& Scholze, 2006). Also, chlorination researchers established that chlorine does not kill cryptosporidium, which is a parasite that enters water sources through sewage (Pampuro \& Grimes, 2012).

Sometime ozonation is used instead of chlorine. Ozonation is regarded as the strongest disinfection method available. It involves passing dry oxygen into a system with high voltage electrodes. Specifically, researchers established that ozonation is one of the most effective water treatments compared to chlorination (Von Gunten, 2003). Besides ozonation and chlorination, ultraviolet radiation, the third option, that is often used to penetrate the genetic composition of microorganisms to prevent their ability to reproduce.

Step 6: Storage. Water is stored in closed reservoirs from which it is delivered to homes (through pipes) for consumption and farming.

The above described large systems for cities and municipalities. Point-of-use (POU) and point-of-entry (POE) treatment systems are described below.

\section{Point-of-Use Water Treatment (POU)}

Point-of-Use Water Treatment is installed in an individual source line ahead of any or all of the taps, faucets, or other dedicated outlets used to dispense water for drinking, cooking, and bathing. POU systems are often a combination of pre-filter, reverse-osmosis (RO) filter, and 
post-filter to capture whatever escapes the POE system. Commercially available POU systems are described below.

Ceramic water filtration. According to Gupta, Verma, and Chaudhuri (1994), ceramic water filtration is a type of water purification that physically removes particulates from solutions using a ceramic filter. Due to its tiny pores, a ceramic filter has the ability to remove bacteria and parasites from any type of water. Moreover, these filters are usually coated with silver to prevent the growth of bacteria in them and sometimes have a carbon core that helps with the taste of water. In the same vein, the filters are cheap, easy to clean, and portable. Hence, they are appropriate for household water treatments in rural Kenya and third world countries. On the other hand, the filters do not remove all pathogens that cause illnesses, and they do not remove chemical contaminants. Further, the ceramic candles are fragile and heavy to transport to rural areas due to poor infrastructure (Franz, 2005).

Solar disinfection in transparent bottles. This is one of the most common household water treatments in the world. This approach is prominent across the world due to its effectiveness in water treatment. It involves the use of ultraviolet radiation, which utilizes DNA and thermal inactivation to kill virus and bacteria, hence, reducing diarrheal-related diseases. The treatment is cheaper compared to other treatments, as long as one uses recycled plastic bottles. Studies that investigated responses to cholera outbreaks note that solar disinfection is effective in reducing waterborne diseases in African countries. Solar disinfection in transparent bottles is cheap and can be used in response to cholera outbreaks in third world countries (Conroy, Meegan, Joyce, McGuigan, \& Barnes, 2001).

Solar disinfection has several drawbacks that its users reported; for example, the systems' bottles treat a limited amount of water at a time due to the sizes. Solar disinfection also involves 
leaving the bottles outside under the sun for a certain amount of time since the system depends on the intensity of the sun (EAWAG/SODIS, 2002), therefore, making the process time consuming and tedious as the families need increased treatment of water every day. An ethnographic study conducted in Africa's largest slum, Kibera, Kenya, notes that since water treatment using solar disinfection in transparent bottles is time consuming, users are discouraged and are forced to use the treated water only for drinking and use untreated water to cook and clean (Brown, 2004). Therefore, solar disinfection in transparent bottles may not be a good household water solution.

Reverse osmosis. Reverse osmosis is the most common water treatment solution worldwide. It has the ability to remove total dissolved solids and a few other harmful water contaminants, improving odor and taste of the water. Some of its disadvantages are as follows: This water purification system wastes $50 \%$ to $80 \%$ of water and requires intensive energy. Without proper maintenance, the filters can easily get clogged, and homeowners who do not have time to maintain the filters may be forced to invest on a pre-filtration system clog. Finally, reverse osmosis removes $92 \%$ to $99 \%$ of the essential minerals including calcium and magnesium. The World Health Organization issued a reverse-osmosis water warning, indicating that the water cleaned by this method is not safe for human consumption (Kozisek, 2005). Research demonstrates that consuming water of low mineral content has a negative effect on homeostatic mechanisms, compromising the mineral and water metabolism in the body. Consumption of reverse osmosis water leads to the dilution of the electrolytes dissolved in the body's water. Inadequate body water redistribution between compartments may compromise the function of vital organs. Side effects at the very beginning of this condition include tiredness, 
weakness and headache. More severe symptoms are muscular cramps and impaired heart rate (Kozisek, 2013).

\section{Safe Water Storage: Modified Clay Pot}

Modified clay pots are made of clay and provide storage for drinking water after water treatment. The pots are enclosed with a lid that prevents water contamination since the users are not able to draw water from it using dirty cups and jugs, which may contaminate the water. Therefore, this system provides safe drinking water (Bovin et al., 2004). As water evaporates through the clay, the water remaining in the pot is cooled.

\section{Point-of-Entry Water Treatment}

Point-of-Entry Water Treatment (POE) is installed at the point where the supply enters the house and it is connected to the house water meter. This kind of water system treats the water for the whole house. Point-of-Entry water treatment systems are installed on the consumers' side of the meter with the purpose of treating all of the incoming water before it goes into the individual supply lines that feed laundry, bathrooms, dedicated outside faucets and others as well as the kitchen. POE systems often include softeners, large bed carbon filters, and some systems that are specifically designed to remove sediment, tastes and odors. The most common POE systems are softeners to reduce hardness and iron curtains to reduce iron present in the water.

Water softeners. Water softening involves passing water containing hardness minerals, such as calcium and magnesium over ion, which displaces the hardness minerals, therefore, softening the water (Robles, 2003). Hard water is softened by removing the calcium and magnesium it contains. When hard water passes through the softening system, ions are removed through an ion-exchange process, so only softened water passes through to the home. Calcium and magnesium also help reduce water hardness. The soft water delivered saves cleaning 
detergents, reduces stains on clothes and utensils, and saves power. However, studies reveal that water treated using softeners is not healthy and desirable for consumption since it increases sodium intake, which is associated with heart disease. Since water is a universal solvent, some metals can still be present in the water because softeners are not designed to remove metals or chemical contaminants (Metropolitan, 2001). Unfortunately, softeners do not remove bacteria, viruses, odor, or heavy metals such as arsenic and lead. Many of these toxic elements are known to cause health risks such as cancer.

As discussed above, most of the commercially available POE systems have limitations. Some of the limitations pose a risk to human health. Most available water purification systems only cater for "water aesthetics" (taste, odor, and color) and are not designed for general "water health." That is, they do not remove all long and short term disease-causing toxic pollutants such as arsenic, lead, thallium, bacteria and virus without addition of harmful substances. An example of water purification system that addresses these limitations is the WaterPOD technology.

\section{The WaterPOD ${ }^{\mathrm{TM}}$}

Stonehouse Water Technologies (SWT) invented the world's smallest and smartest water patent pending purification system called WaterPOD 8 (see figure 3). The WaterPOD is an ondemand water purification system that is effective in households and commercial water treatment processes. The WaterPOD requires 120 volts AC-25 watts/hour and maximum pressure of 90 psi. It can be installed at the entry to a house or in a private well after the pressure tank. Its maximum flow rate is 15 gallons per minute. A one inch inlet and outlet pipes are required for this system. 


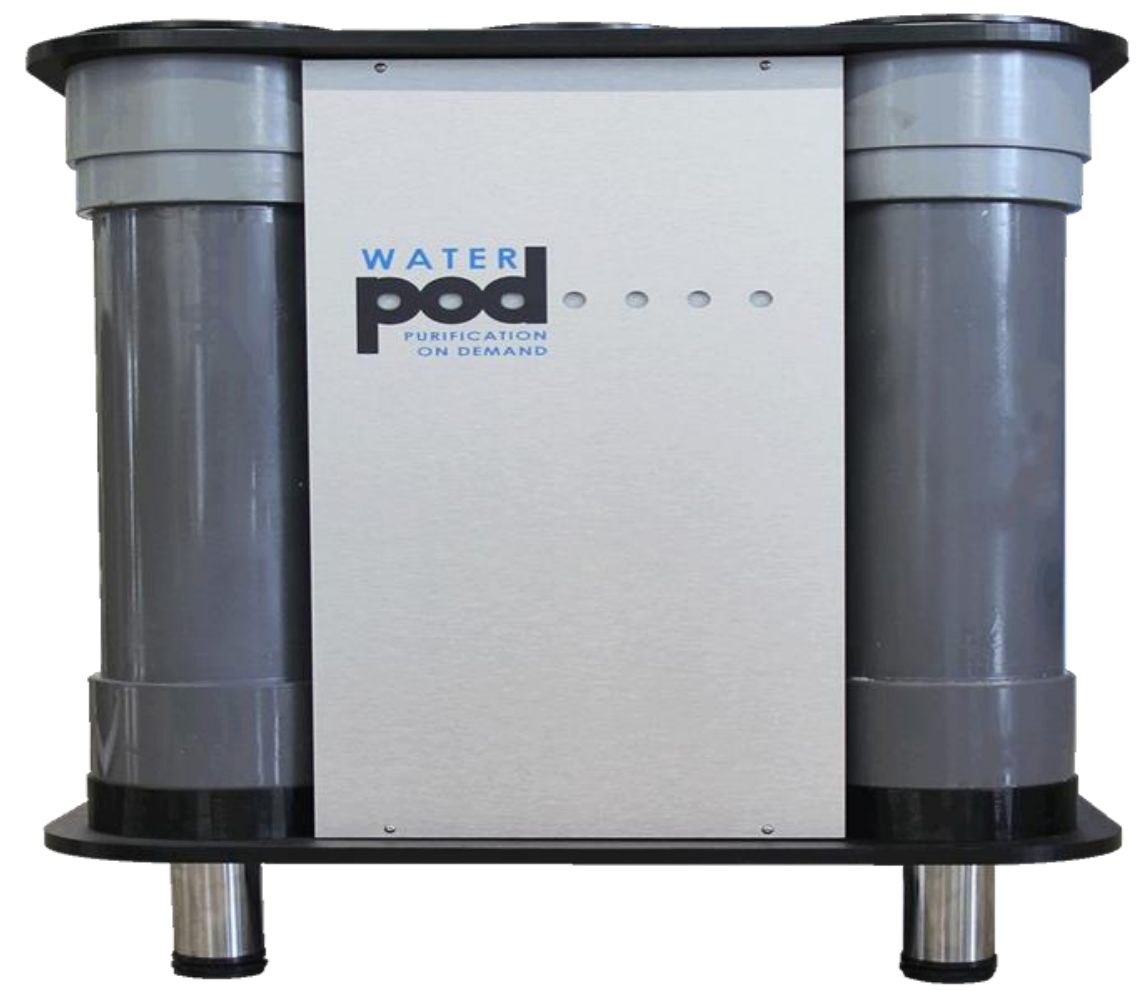

Figure 3. The WaterPOD.

This system does not require addition of any chemicals for purification and allows modification of different kinds of filters depending on the water quality. The process of extracting high-quality drinking water does not take time since the WaterPOD is an on-demand water purification system with eight water purification units as shown in figure 4 . The WaterPOD is pre-engineered, that is, it comes complete and ready for installation. The WaterPOD is equipped with a real-time monitoring smart technology with Internet of Things (IoT), which refers to the billions of physical devices around the world that are connected to the internet, collecting and sharing data. The IoT sends updates to the users, such as alerts on filter changes, pressure drops, flooding, and power outages. 


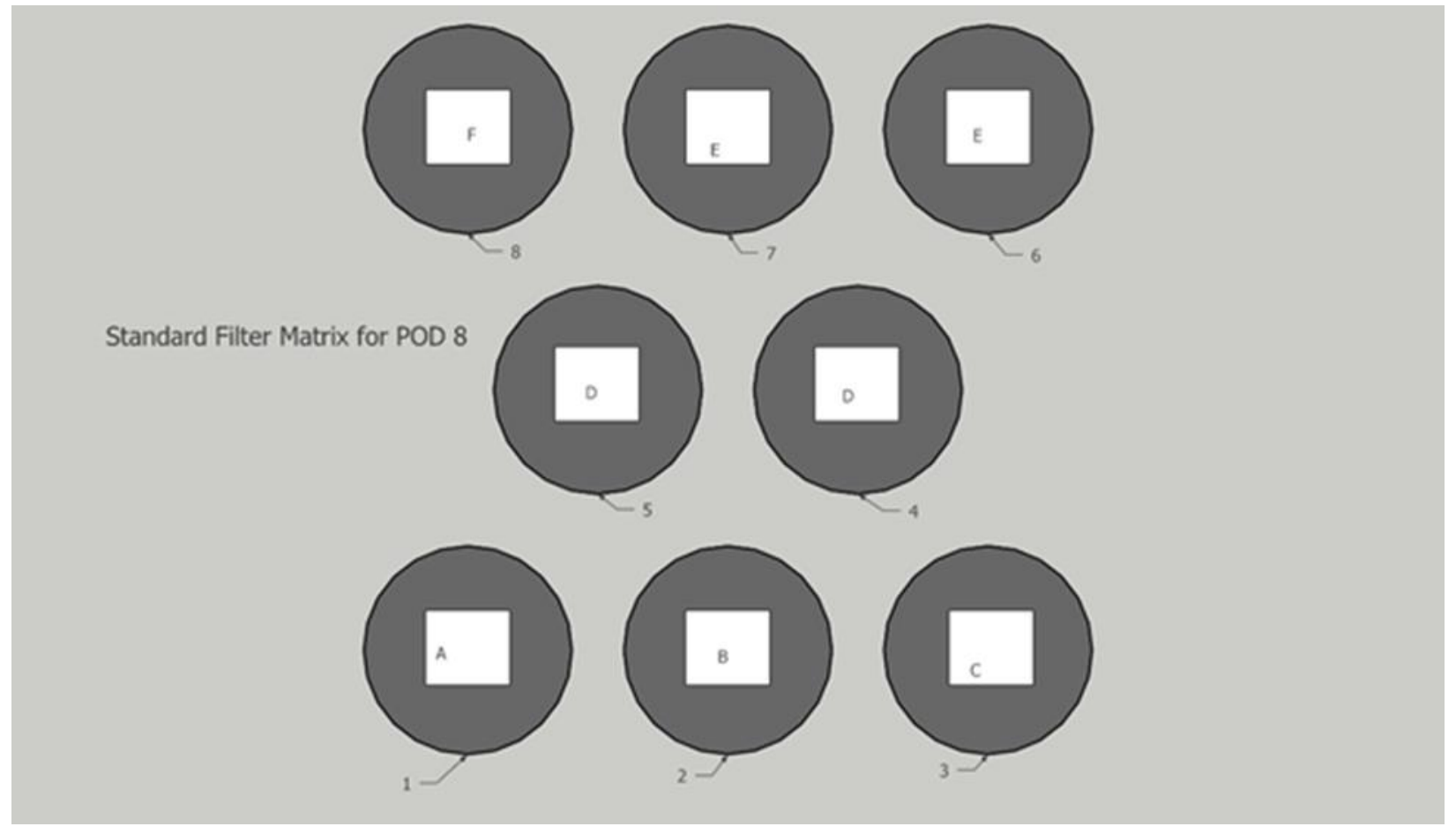

Figure 4. The 8 stages of the WaterPOD.

WaterPOD 8 has eight units devices installed in a 'monolithic' platform that contains different types of filters designed to trap/remove contaminants in one complete water filtration system. All the filters are commercially available and filter change time depends on the water quality. These include:

Cylinder A - $1 \mu$ DGD-250-20, Dual Gradient Density Spun (Sediment Filter). The first stage the WaterPOD is a one-micron poly-spun sediment filter that traps large sediments and other particulate matter like dirt, silt, and rust, which affect the taste and appearance of water. The sediment filters are supplied by Pentair and are National Sanitation Foundation (NSF) 42 certified for drinking water.

Cylinder B - Lead Reduction Filter- Pb1 06-450-20 GREEN. The lead reduction filter reduces lead. The Lead reduction filters are supplied by Matrikx and are (NSF) 42 certified for drinking water. 
Cylinder C. Biocide Media Filter. The WaterPOD is a one-micron biocides filter that kills bacteria organisms. It minimizes bio-film accumulation on hollow fiber membranes. The filters are supplied by MetaMateria and their performance validated by an independent laboratory (University of Wisconsin-Whitewater).

Cylinder D and D. Two Membrane Filter- 0.1 $\mu$ TA13045MF-Hi Flow. The fourth and fifth units contain the Hollow Fiber Membrane. This semi-permeable membrane removes the finest organics. It reduces total dissolved solids, sodium, and a wide range of contaminants such as chromium, arsenic, copper and lead, as well as Cryptosporidium. Membrane filters are NSF 42 certified for drinking water and are supplied by NOK.

Cylinder E and E. $0.5 \mu$ Carbon Block Filter Cartridge. The carbon filters reduce cyst (such as Crypto, Giardia). These filters help with odor, taste, and a few metals such as arsenic. That is, the carbon filters also help ensure that chlorine and other substances that cause bad taste and odor are greatly reduced. Carbon filters are NSF 42 certified for drinking water and are supplied by Pentair.

Stage F. Ultraviolet Light. The eighth and last unit is the UV light, which is the most effective method for disinfecting bacteria from the water. Ultraviolet (UV) rays penetrate harmful pathogens in the water and destroy illness-causing microorganisms by attacking their genetic core (DNA). UV light destroys $99.99 \%$ of harmful microorganisms without adding chemicals or changing water's taste or odor.

Pre-filtration system. In areas where the water quality is poor, a sand filter may be required as a pre-filtration tool. To improve durability of the WaterPOD's filters, the Menomonee River project (see next section) included a medium that helps in water purification. 
The sand filter traps large dirt and sand particles using a mesh wire. The sand filter has a sensor that detects water contaminants.

\section{Simulating the Applicability of the WaterPOD Technology to Third World Countries}

\section{The Point of Grace Academy Project in Kisumu, Kenya}

The Point of Grace is a school of 800 children between the ages of 5 and 15 . The school is located in the rural area of Kisumu along the shores of Lake Victoria. This region is known for having the highest levels of HIV/AIDS in Kenya. The Point of Grace academy obtains its water from Lake Victoria. Lake Victoria is shared by three East African countries; Kenya, Tanzania and Uganda, thus, it is highly polluted (Akurut, Niwagaba, \& Willems, 2017).

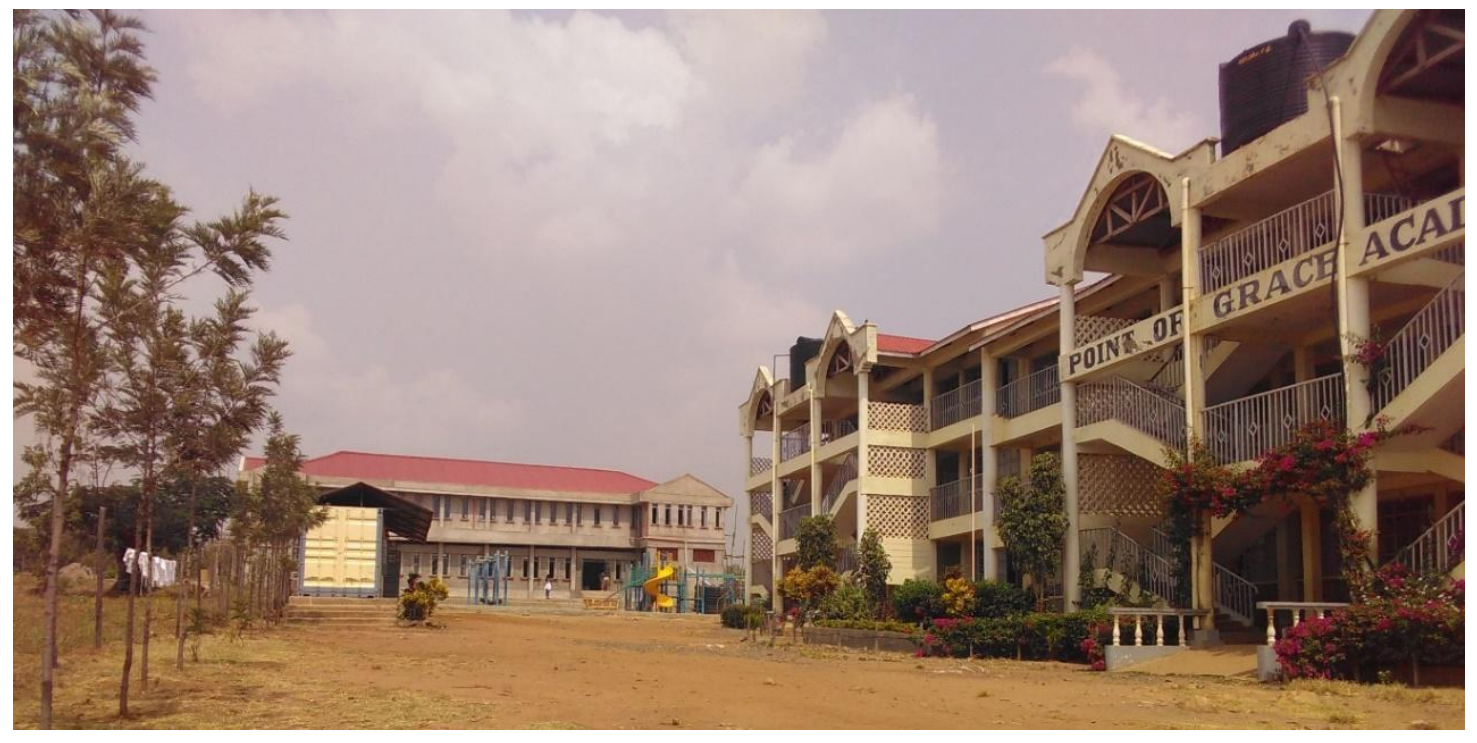

Figure 5. Point of Grace Academy about 700+ children in need of clean water.

Consequently, the school is facing water problems and cases of water-borne diseases have been common among school children and the surrounding community. Over the last months, the researcher strived to provide solutions to this problem and did field research along Menomonee River. To utilize health communication theoretical knowledge, the researcher 
designed a training program to deliver the findings and training individuals on how to use technology to improve water health.

\section{Menomonee River Pilot Project (MRP)}

Working alongside Dr. Moe Mukiibi, a globally recognized water expert and technology innovator, as a Research Fellow, the researcher ranked all commercially available water treatment options through a defensible multivariate analysis selection criterion to understand the effectiveness of the filters and water purification processes for skills and knowledge transfer. The activities concluded that about $90 \%$ commercially available options have limitations and are not applicable to developing countries and that the WaterPOD would be the most viable option when modified to purify high contaminated waters. An applicable media analysis also revealed the best set of filters for highly contaminated waters. Moreover, an instructional media (described in the following sections of this chapter) were selected.

The Menomonee River in Wisconsin is known as one of most contaminated rivers, which is polluted with bacteria, viruses, and heavy metals (see water quality report under appendix pg. 102). To simulate Lake Victoria conditions, the researcher conducted a pilot test study using the WaterPOD along Menomonee River over the summer of 2018. The water quality of Menomonee River required a combination of the sand filter and the WaterPOD technology to achieve safe drinking water guidelines. The purpose of this project was to determine the filters' run time, the water volume purified, and the effectiveness of best set of filters in highly contaminated water.

First, the researcher chose a combination of different types of filters to establish the most effective filter system in highly contaminated waters like L. Victoria. Second, raw water from the canal was collected for testing. Third, purified water samples were also collected every hour for testing. Later, the water test results were contrasted to determine the effectiveness of the 
system. Table 1 is a brief description of the results gathered, contaminants, and their possible health concerns. For a more detailed report see Appendix A (pg. 107), which contains all the contaminants present in the water sample before and after the WaterPOD. The test results after the WaterPOD sample show the effectiveness of the technology as all the contaminants were either removed or reduced to the acceptable safe level.

Table 1

Menomonee River Pilot Project Contaminants Cause and Their Possible Health Concerns

\begin{tabular}{|l|l|l|}
\hline Contaminants & \multicolumn{1}{|c|}{ Health Concerns } & \multicolumn{1}{c|}{ Possible Sources } \\
\hline Cadmium & Kidney damage & Corrosion of galvanized pipes, erosion of natural \\
& deposits, discharge from metal refineries, runoff \\
from waste batteries/paints
\end{tabular}

Table Continues 


\begin{tabular}{|l|l|l|}
\hline Contaminants & \multicolumn{1}{|c|}{ Health Concerns } & \multicolumn{1}{c|}{ Possible Sources } \\
\hline Mercury & Kidney damage & $\begin{array}{l}\text { Erosion of natural deposits, discharge from } \\
\text { refineries and factories, landfill and crop land } \\
\text { runoff }\end{array}$ \\
\hline Nickel & Nausea, vomiting & Discharge from steel and metal refineries \\
\hline Potassium & $\begin{array}{l}\text { Alteration of blood } \\
\text { pressure, irritation of the } \\
\text { skin }\end{array}$ & Runoff from fertilizers, naturally occurring element \\
\hline Silver & $\begin{array}{l}\text { Dizziness, vomiting, } \\
\text { diarrhea }\end{array}$ & Naturally occurring element, preservatives, \\
disinfectants
\end{tabular}

The analysis of different filter combinations, water volume produced, and purification effectiveness led to the discovery of the best set of filters in highly contaminated water as shown in the figure 6 . The set of filters is readily available at stores and could be used in internal displaced persons' camps, businesses, schools, and homes worldwide with little or no modification depending on the water quality. 


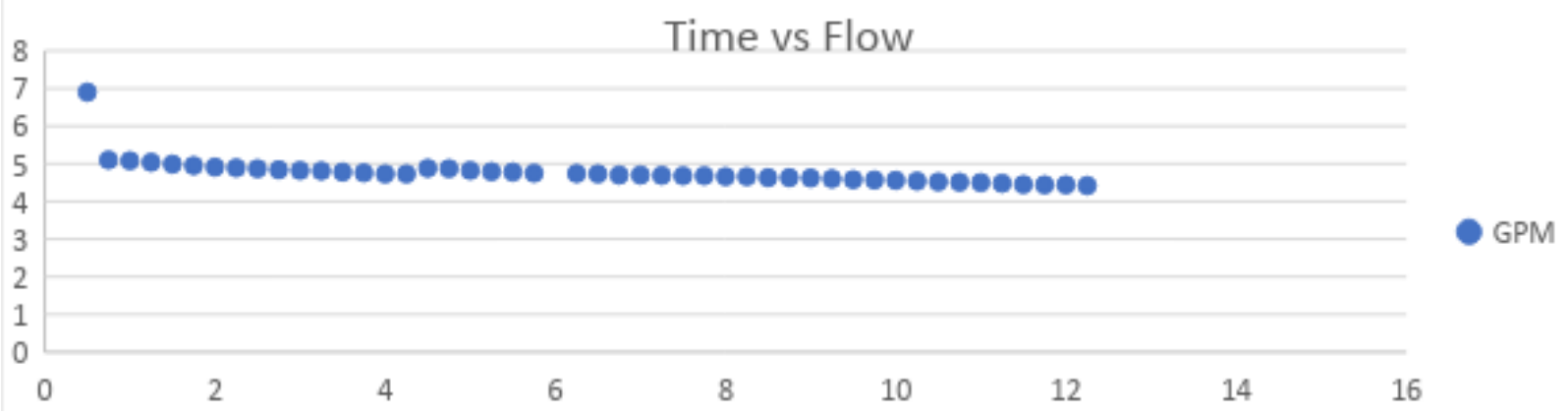

Figure 6. Best filter combination for a highly contaminated water source, which treated 3636 gallons in 12.5 hours.

\section{Conclusion}

This chapter demonstrates the importance of water and good health depends on water quality. Water can cause short- and long-term diseases across all ages. Different settings use water for different purposes that improve individuals' quality of life. However, research shows that water source contamination is the leading cause of diseases. It is interesting to note that the water quality is deteriorating worldwide. There is need to protect water sources from human and industrial contamination. This chapter also demonstrates indirect contribution of water to world peace and gender inequalities. These problems require different world bodies to join forces for drastic measures to sensitize the world to the need to protect water sources, to mandate water testing, and to promote Point of Entry water purifications systems. It is important to note that not all systems can remove all water contaminants and that new contaminants are emerging (pharmaceuticals) all the time. Since water quality is constantly changing, innovation of systems (Water POD) that can be modified to suit the changes is vital. The next chapter focuses on health education and literacy. 


\section{CHAPTER III: WATER HEALTH COMMUNICATION}

The previous chapter presents literature on water quality, treatment methods available to the public depending on their water quality needs, source, and related problems. The present chapter looks at the role of health literacy and communication in public water health promotion. Health Belief Model and Diffusion of Innovations theoretical frameworks guided this study. This chapter also introduces the frameworks and their application in different health sections.

\section{Health Literacy and Communication}

Kickbusch (1997) defines health literacy as "the achievement of a level of knowledge, person's skills, and confidence to take action to improve personal and community health by changing personal lifestyles and living conditions" (p. 269). Published studies over the years describe education and its relationship with global health status indicators. For example, Raznaan et al. (2000) reveal a direct association between mother's level of education, adult literacy, and infant mortality in developing countries like Kenya. Studies have consistently shown that failures in health education are associated with poor health literacy (Peterson, Shetterly, \& Clarke, 2011). In addition, the failures are increasing because the health systems are becoming more complex and individuals are more encouraged to seek self-care (Nutbeam, 2000). Even though poor health literacy may seem to be entirely inherent in educational systems, other factors are important for good health, for example, social economic factors (Williams, Yu, Jackson, \& Anderson, 1997).

The inclusion of formative research in creation and implementation of scientific-based communication and the use of technology and partnerships is increasing while feedback is important to modify campaigns or messages to achieve a desired action (Rootman \& Goodstadt, 2001). Therefore, scientific-based communication may utilize audiences' feedback to meet their needs and preferences to succeed in advocating for good health. 
Good health communication means getting the right information to the targeted groups of people, with the intended effects of the senders, which incorporates ethical arts and strategies for conveying information. Therefore, communication should not be viewed as something that is only technologically based but as an aspect that involves time, ethics, effects, and audiences (Ratzan, 2001). The essence of health communication for public good is rooted in the guidelines of rhetoric. Tracing the evolution of health communication, studies indicate that it adds value to health, facilitates decision-making based on science and theoretic frameworks, leads to progressive opinion leading individuals, and brings together public and private health sectors and policy makers (Ginter, Duncan, \& Swayne, 2018; Minkler \& Wallerstein, 2011).

\section{Education and Training}

Health educators and trainers have explored how the Diffusion of Innovations and Health Belief Models support long-term health behavior change. For example, concepts of these theories offer important insights in adoption of HIV prevention across cultures (Paulussen, Kok, Schaalma, \& Parcel, 1995). Health education for high-risk individuals, patients, their families, and the surrounding community, as well as in-service training for health care providers, is an important part of healthcare today. Health education provides channels for delivering programs such as training to certain populations through existing communication systems that facilitate development of positive behavior change (Mullen et al., 1995).

Over the years, lack of training spaces or communal halls in rural areas has led to the use of classrooms to conduct public health training (Luepker et al., 1996). This kind of training could be teacher training, and it could focus on transitions to new school environments that support healthy behavior (Franks, 2007). Interventions focusing on community have used peer influence to promote disease prevention in clubs and neighborhoods (Sorensen \& Barbeau, 2006). Training 
has also promoted cancer awareness, nutrition and cardiovascular among minorities (Sorenson et al., 1996). In an effort to manage work-related stress, organizations use health promotion and wellness training programs to provide social support (Israel \& Schurman, 1990; National Center for Health Statistics, 2001).

\section{Training and Self-Efficacy}

Self-efficacy is the degree to which individuals feel confident to produce designated level of performance on specific behavior that influences their lives (Bandura, 1994). Bandura points out the need for individuals to be able to regulate their motivation through environment and processes to attend desired goals. Perceived self-efficacy, conceptualized as perceived operative capability, has the ability to influence individuals' feelings and behavior. It focuses on an individual's perceived ability and belief about what they can do with the resources they can assemble and not just what they currently have. To determine self-efficacy in a certain health behavior, researchers ask individuals to rate the extent that they feel they can execute a behavior under a certain circumstance rather than the abilities they possess (Bandura, 2007). The greater the level of self-efficacy, the greater the likelihood of individuals adopting and adhering to healthy behavior. It is conceptualized as a message's property that contains health information that increases its audiences' confidence in performing tasks (Turner, Rimal, Morrison, \& Kim, 2008).

Self-efficacy can affect people's feelings and behavior. For example, individuals with low self-efficacy are less likely to resist the pressure from their partners to have unsafe sex (Kasen, Vaughan, \& Walter, 1992). Most health communication studies measure self-efficacy on a specific behavior depending on the study's focus. These behaviors include confidence to quit smoking, confidence to perform breast cancer tests, and confidence in learning new behaviors. 
These studies focus on specific measures tailored to particular disorders since self-efficacy vary from study to study.

In protection motivation theory, self-efficacy is the central concept to fear appeals (Rogers, 1983). When threat and response efficacy are low, individuals are motivated to reduce the fear appeals using different strategies, for example, message derogation and message avoidance. And if both efficacy appraisals are high, individuals are more likely to adopt to a recommended behavior.

As one example of this concept, training as an intervention increases self-efficacy for condom use in an effort to promote safe sex. Siegel Aten, and Enaharo (2001) conducted an intensive 12-session training that incorporated health classes and focused on decision-making skills to increase efficacy. They found a significant increase of self-efficacy with intentions to be safe among the intervention group respondents. DiClemente, Schlundt, and Gemmell (2004) observed a significant decrease in inappropriate sexual behavior among adolescents who received safe sex training targeting self-efficacy for condom use and safe sex communication and negotiation skills. Even though many studies that explored the relationship between selfefficacy and risk-reducing behaviors have reported significant results (Glassman, Franks, Baumler, \& Coyle, 2014: Mahat, \&Scoloveno, 2010), a few were not consistent (Forsyth \& Carey, 1998).

Investing in training of policy makers and its stakeholders on social determinants of health is important in improving health outcomes. Training on public health and specific important determinants of social health should be embedded in curriculum for medical schools, campuses, and faculty tests and examinations. Consultation between students, senior students, 
and doctors is highly encouraged in development of curriculum and its implementation (Atkinson \& Cottam, 2011).

As it relates to the present study, training increases self-efficacy in water health as demonstrated by several studies. For example, Blanton et al. (2010) postulate that the success of the diffusion of water treatment in Nyanza, Kenya, was as a result of the training the teachers received. During training, the teachers were trained on various methods of training and were motivated to educate people in their schools. The teachers then were trained on how to instruct students to understand water treatment methods. Safe drinking water clubs were formed to help students develop their own projects related to water treatment. After training, the students were issued comic books that illustrated how to prevent diarrhea using a water guard. To facilitate better understanding of the books' content, trainers held open discussions, encouraging students to demonstrate to their parents what they learned. Therefore, the present study utilizes education and training program as the appropriate approach to increasing self and operational efficacy in the use of water filtration systems. The program employs two health communication theories that explain behavior change.

\section{Theoretic Framework}

This study is rooted in two health communication theories, namely, Health Belief Theory and Diffusion of Innovation Theory.

\section{Health Belief Model}

Godfrey Hochbaum, Stephen Kegels, and Irwin Rosenstock conceptualized the Health Belief Model (HBM) in 1952. The model explains and predicts preventive health behavior in terms of specific beliefs such as condom use and waterborne disease prevention. The health belief model was later revised to cover a wider scope of general health motivation in order to 
distinguish illness-and sick-role behavior from health behavior. The model assumes that individuals are more likely to adopt recommended behaviors if an individual: (a) feels that a negative health issue can be avoided; (b) has a positive attitude or expectation that by taking the recommended action they will avoid the negative health conditions, and (c) believes that they can adopt the recommended action with confidence. For example, the more an individual in the rural part of Kenya recognizes that cholera is a serious illness and that they are susceptible to it if they continue drinking unsafe water, the more they are likely to use water purification systems.

The model divides an individual's motivation to health behavior into three categories: First, individual perception involves the individual's perspective of the disease and how important health is to the individual, in terms of perceived susceptibility, threat, and severity of the consequences if the threat materializes. Perceived benefits focus on an individual's beliefs of self-efficacy of the recommended behavior to reduce the chances of getting the condition. Perceived barriers deal with the tangible and psychological costs of the recommended behavior.

Second is the modifying behavior. Under this category, the model describes demographic variables and the cues of action. The last category of the HBM is the likelihood of an action; this includes the possibility of an individual taking the recommended preventive health measure or action.

Researchers have widely applied the HBM model in their studies. It is used to guide health promotion and disease prevention programs. Its concepts are effective in assessing and motivating health behavior change, for example, in reproductive health.

Reproductive health. In reproductive health, individuals engaging in unsafe sex are at risk of contracting sexually transmitted diseases. Information on the likelihood of being infected with STDs makes individuals perceive that they are susceptible to STDs or HIV since they are 
exposed to various situations such as having unsafe sex with infected partners. Individuals believe that the consequences of STIs without access to treatment are severe and, therefore, need to be avoided. The benefit of using condoms is that it protects individuals from getting STIs, minimizing the consequences and the chances of infecting others.

Applying the HBM to this issue would highlight the individual barriers to using condoms such as embarrassment when buying them, mostly in African cultures, as Agha (2003) notes, or not being able to propose condom use with their partners. It would also provide solutions to reduce the barriers associated with condom use, for example, use of lubricants to prevent condom breakage and creating platforms for condom discussions to ease the embarrassment that individuals from conservative cultures face when buying condoms. The last concept, that is, the cues to action, would suggest providing reminders for condom use in more entertaining ways, for example, free magnets with positive information about condoms.

Mass media campaigns have utilized the HBM to encourage the use of condoms and other forms of contraceptives in the context of the family planning. In countries such as Tanzania, studies on the exposure of family planning campaigns, specifically those advocating for condom use, show that the more women are exposed to different forms of media, the more they will use contraceptives (Valente, Watkins, Jato, Van Der, \& Tsitsol, 1997). The findings further reveal that women who remember many positive family planning media programs or commercials discussed the contraceptives with their spouses more than those women who remembered few commercials. This means that the condom commercials are able to initiate conversations between partners, increasing the likelihood of the couple using the recommended protection. 
Media are made up of groups of institutions that have the power to influence behavior, beliefs, attitudes, and emotions (Thompson, Parrott, \& Nussbaum, 2011). In Thompson, Parrott, and Nussbaum's (2011) view, media not only provide information but also affect the beliefs and values of the consumers guided by theoretical framework such as HBM. Further, the abovementioned studies note that the power of the media extends beyond the information suppliers to agenda setting. For example, a cross-sectional study in China that investigated condom use behavior based on the health belief model among female sex workers (Zhao et al., 2012). The researchers found that the perceived benefits and barriers were the proximate determinant of condom use. Self-efficacy has a direct effect on perceived severity, perceived benefits, and perceived barriers, which were indirectly related to condom use.

In Kenya, Agha (2003) results showed that exposure to condom messages was related to self- efficacy. The greater the perceived efficacy of condoms, the lower the perceived difficulty in obtaining and the perceived awkwardness in buying them. On the other hand, other studies such Nyaga (2016) results show that the efficacy of health communication interventions through effective sexual health education, involving target communities in the design and implementation of campaigns such as the current training program, effective use of condoms, faithfulness to one's partner, and allocating adequate resources to the proposed interventions.

To conclude the above section, it is clear that manty studies have utilized the HBM model promote of sexual health and discouraging unhealthy behaviors such as smoking. In the next subsection, the researcher explicates the application of HBM model on water health promotion.

\section{Health Belief Model and Water Health}

The HBM has not been applied to water treatment studies and campaigns. Based on the knowledge of the HBM model and knowledge on water contamination discussed in chapter 2, 
HBM can be used in water health by advocating water treatment technologies or purification systems such as the WaterPOD as follows;

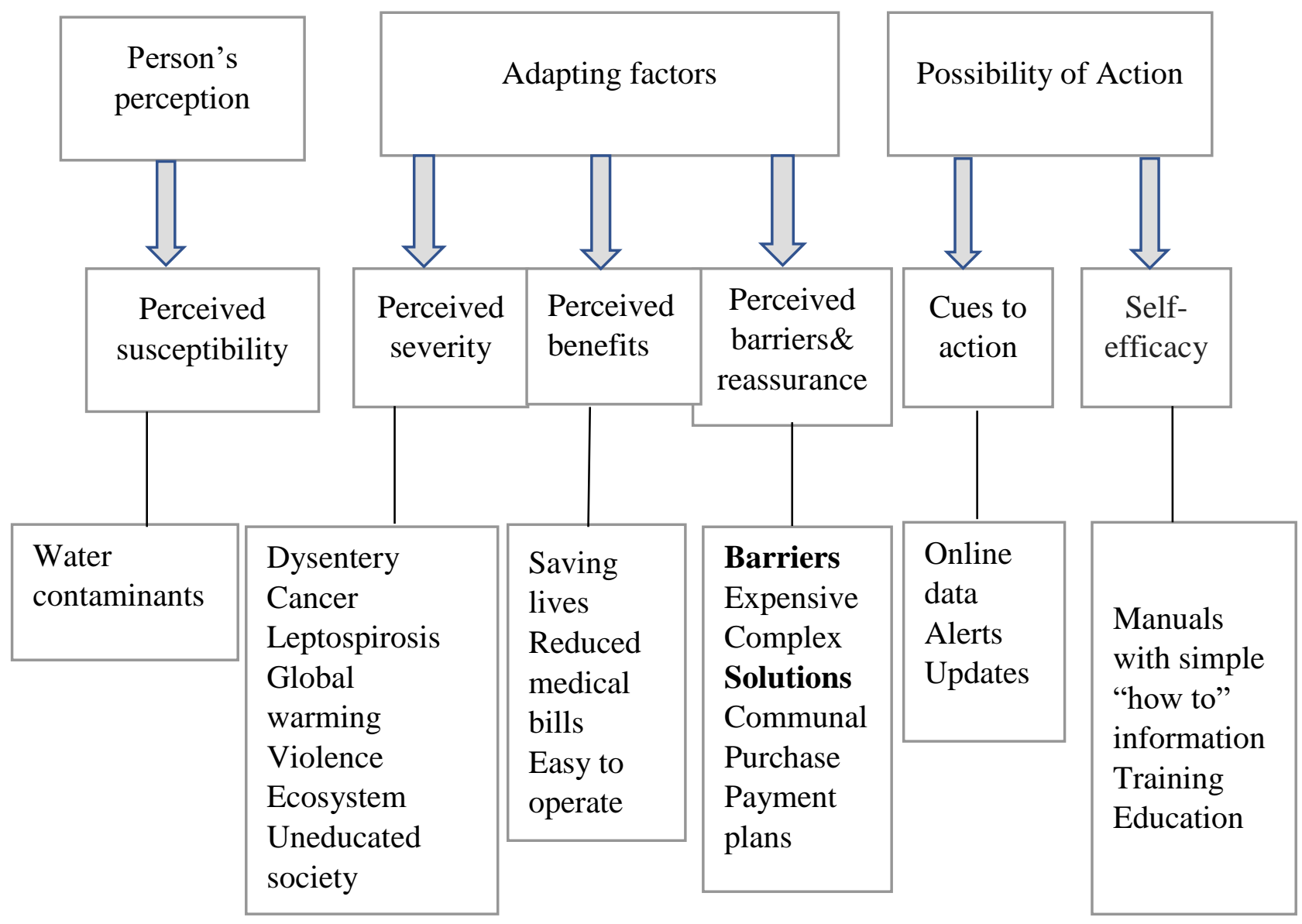

Figure 7. Application of HBM on water health.

Perceived susceptibility highlights the fact that people all over the world are at risk of contracting waterborne diseases and other negative health conditions caused by unsafe drinking water. These problems cause individuals to be skeptical as to whether the water they are drinking could have contaminants that can cause illnesses. Individuals' perceptions of their water quality determine how likely they are to adopt water treatment methods. Perceived severity, the consequences of drinking untreated water are very serious and may lead to death or diseases such as cholera, diarrhea, cancer, and global warming. The perceived benefits of having a water 
purification system (e.g., the WaterPOD) is that it protects individuals from getting short- and long-term waterborne diseases, therefore, saving lives and finances that could be used in treating the diseases.

Perceived barriers to using water purification systems are that individuals may lack knowledge on how to use them, and, as a result, contaminants can still find their way out of the systems into the body, causing diseases. Additionally, the WaterPOD may be expensive for some people; some replacement parts are not readily available globally. Therefore, providing information on how to reduce the barriers associated with buying a water purification system is vital. For example, training can provide facts on how many people the system can serve. In this case the WaterPOD serves about 100 people if each person is using a maximum of 50 gallons of water a day. Suggesting that different houses/apartments can come together and raise some money for one system may be one way of overcoming financial issues. During the MRP research on the WaterPOD, the researcher created a WaterPOD installation manual that gives information on acquisition of replacements part information and how to replace them.

The cues to action provide reminders in more entertaining ways, for example, flyers linking safe drinking water with long life. The WaterPOD online data and the real-time monitoring smart technology to send reminders facilitate the cues to action. The manual provides step-by-step instructions on how to troubleshoot and operate the WaterPOD. Therefore, users feel they are in control of the products and their own health.

The last concept is self-efficacy. This involves providing training to the users to help them continuously use the product to promote good health. Face-to-face presentations, videos, and training manuals can be very helpful in regard to this concept, since most of the users of this water treatment system may not have an engineering background. Even though HBM does not 
provide specific ideas of how a health-related training manual should be developed, it endorses training as an effective method to facilitate health behavior change through increasing individuals' self-efficacy.

As described above, HBM is more descriptive than explanatory and does not offer a clear strategy for changing behavior, leaving room for speculations and explorations. The model also assumes that individuals have equal access to communication channels that provide cues to behavioral change. In fact, it does not acknowledge the knowledge gap that diverse individuals have and the different aspects that play into the kind of information available to them.

Specifically, it does not consider personal aspects such as skills, knowledge, and motivation level that individuals have in water treatment; environmental or economic barriers that individuals living in developing and third world countries have in purchasing water purification systems. Additionally, it does not factor in cultural issues such as perception of dumping trash in water bodies. Lastly, it does not consider habits that may inform decision-making processes in adoption of the recommended health behaviors. With the aforementioned limitations of the HBM, integration of other models that consider personal, environmental, economic, and cultural aspects for effectiveness of the model is vital. Therefore, this study also uses the Diffusion of Innovation theory to bridge the gaps in HBM.

\section{Diffusion of Innovations Model}

Diffusion of Innovations (DOI) seeks to explain how, why, and at what rate ideas and technologies are taken up in a population. It acknowledges that behavior change arises through contact with populations' internal and external forces (Rogers, 2003). Diffusion refers to a macro-level process by which innovations are introduced into a society through diverse communication channels over a period of time. Adoption focuses on the stages through which 
individuals pass to fully embrace an innovation to make it part of their day-to-day lives (Weigel, Hazen, Cegielski, \& Hall, 2014). Credibility of the source of information, superiority of the innovation compared to existing ones, and its diffusion in the society determine the pace at which the innovation diffuses (Farr \& Ames, 2008). Schumpeter (1930) defines innovations as any new ideas, methods, or products that provide solutions to new and existing needs of a specific market needs, in this case, water treatment procedures and products. However, Rogers (1998) argues that innovations not only include knowledge creation but can also apply to the diffusion of existing knowledge within a social system. DOI offers insightful concepts in the process of behavior change.

Characteristics of the innovation. First, the theory describes the characteristics that make an innovation likely to be adopted. DOI as a theory focuses on social change based on the renovation of the products or services and behavior that fits individuals' needs rather than persuading individuals to change. Renovation is a key principle of DOI because it determines how well an innovation develops to meet the changing needs and diverse needs of individuals. Renovation also assures the continual improvement of spreading ideas. The success of new ideas and behaviors are determined by the following characteristics (Rogers, 2003):

Relative advantage. Relative advantage focuses on socio-economic aspects such as social status, affordability, convenience, and enjoyment. The higher an innovation's perceived relative advantage, the more rapidly the innovation spreads, and the greater its likelihood of adoption. Additionally, perceived relative advantage depends on the users' needs and perceptions (Rogers, 2003). 
Compatibility. This refers to the extent to which new ideas and behavior fit in with individuals' existing norms, beliefs, and needs. Innovations that solve eminent problems are highly adopted.

Complexity. This refers to the extent to which an innovation or change is easy to understand and pursue. Innovations that do not require individuals to gain new skills in order to adopt or use have a higher chance of adoption since the users already know what they entail.

Trialability. This refers to the extent to which an innovation is executed on a limited basis. Ideas, practices, or technologies that can be put into practice on a small scale by target population are more likely and easily to be adopted.

Observability. This refers to the degree of visibility of the innovation's outcome to others. Visibility ignites peer-to-peer conversations and discussions across society and reduces uncertainty as neighbors of adopters often request information. This increases the rate of adoption of the new idea and gives it social currency (Hoover \& Stewart, 2001).

The decision-making process. Second, DOI describes the process of decision-making of the individuals adopting an innovation. Haider, Pal, and Al-Shaura (2005) describe the stages of decision making. Knowledge entails individuals' acknowledgement of innovations and seeking knowledge as they strive to understand the innovation. At the persuasion stage, individuals start to develop either positive or negative attitudes towards the new product, idea, or behavior, and, thereafter, may adopt or reject the innovation. Cost-benefit aspects play a part in the persuasion stage. The decision stage occurs after individuals weigh the costs and benefits to either adopt or reject the idea. It is difficult to gain empirical evidence at this stage. The innovation-adaptation decision can be personal, collective, or authority-driven, depending on the situation. At the implementation stage, individuals adopt the recommended product or behavior into their daily 
lives. Adopters determine the usefulness of the innovation by searching for additional information on the innovation they are adopting. And confirmation occurs when adopters of an innovation actively seek information that reinforces the new ideas. At the confirmation stage, adopters can engage intrapersonal or with interpersonal confirmation groups to affirm that they made the right decision.

Aspects of adopters. Third, DOI sees individuals' characteristics as factor that determine the speed at which innovation are adopted. This theory predicts the rate of adoption using the length of time required for a certain percentage of members of a society to adopt a new idea. Rogers (2003) introduces strategies that facilitate innovation introduction into the social system. DOI offers concrete strategies for diffusing an innovation relevant to the present study, which involve impersonal marketing methods (e.g., opinion leaders). To reduce uncertainty, individuals seek credible assurance from others known to them that the innovations are worth adopting.

Research has found that opinion leaders' campaigns are successful in promoting the standards in healthcare providers and safe sex among same sex couples (Fish, Papaloukas, Jaspal, \& Williamson, 2016). Opinion leaders increase compliance in adoption of innovations. For example, Barker (2004) notes that opinion leaders act as brokers of health-related information and play a greater role in persuasion stage of products in rural areas. In Barker's study, the goal was to promote consumption of vitamin A among pregnant women by planting foods rich in it. Elsewhere, young men were used to advocate awareness of gender-based violence, using educational materials that discouraged stereotypes and male chauvinism (Haider et al., 2005). Opinion leaders tend to have a greater exposure to mass media, social exposure, are more innovative than others, are higher in socioeconomic status, and have greater contact with 
innovators. Consequently, opinion leaders are seen as change agents and can influence the attitudes of audiences when it comes to health promotion campaign such as water treatment.

Stages of adopters. Fourth, DOI researchers believe that members of a society are categorized into innovators, early adopters, early majority, late majority, and laggards. As far as its innovation attitudes are concerned, people in each category tend to have different characteristics. Innovators are the visionaries and imaginative group of a society. They are usually a small group in the society who are open-minded and well-educated. They value creativity regarding creating new gadgets and ideas that provide solutions to existing and new social problems. Innovators are always the first people to adopt new ideas (Rogers, 2003). Tracking innovators, and partnering, or becoming their followers is the most effective way to work with innovators. Early adopters are less adventurous compared to innovators yet are still quick to adopt innovations. Early adopters love to be the first to benefit from new ideas and innovations over their peers. They usually have money and time to invest on new ideas. Just like the innovators, the early adopters are well connected and informed on various new trends. They determine the success of an innovation as they are usually socially respected in the society and usually do not require any persuasion to adopt ideas as they are always on the lookout for new ideas. That is, a positive or negative feedback from early adopters affects the diffusion of an idea or product.

The early majority refers to the people who adopt an innovation after the early adopters. They are cost sensitive, pragmatic, and comfortable with moderate progressive innovations. The late majority are the innovation-conservative members of the society who are uncomfortable with new ideas. Due to the fear of fitting in, the late majority are forced to invest in new ideas or products. The late majority usually have below-average social status with little financial 
liquidity. And finally, laggards are people who see innovations as high risk and are challenged by new ideas. Laggards may not admit that they are afraid of adopting innovations. Thus, they do not share their concerns with others, unlike the late majority. In terms of leadership, laggards show no interest and their opinions do not affect the diffusion of innovations.

The role of technology. Social networks played a crucial role in diffusion of ideas before the introduction of the internet. The internet has given innovators a diffusion process of their ideas and products. Studies show that innovations diffuse rapidly in areas where there are stronger interpersonal networks. DOI shows that social systems facilitate dissemination of information, as members are able to share information about ideas and products freely (Backer \& Rogers, 1998). The perception of individuals' networks of a product plays a greater role in adoption of innovations. Valente et al. (1997) observed that respondents reported using contraception after their social network had recommended it and used it. In the social system, organizations play a major role in diffusion of innovations as they make major decisions in adoption of new ideas and products. Adoption decision-making in organizations often occurs by consensus.

The theoretical (HBM \& DOI) and applied explorations utilizing the frameworks described here show practical approaches to health promotion in changing risky health behavior in society. On the other hand, medical interventions focus on prevention interventions such as advocating for safe drinking water and use of medication to prevent dysentery diseases (Orleans, 2010).

On the other side, Collins, Hawks, and David (2000) emphasize the need to identify authentic opinion leaders, as their influence may be determined by situation or the product or idea. That is, not all contexts require opinion leaders to lead change. For example, in Kenya, 
Blanton et al. (2010) note that school children were used to advocate for better water treatment and sanitation in their households. Children's knowledge appeared to translate to their households as their guardians' knowledge of water treatment increased using locally available products. Blanton and colleagues note that the use of school children as diffusion agents was as successful as any other program launched in the region, as people know that schools are venues for educational material.

\section{Conclusion}

To sum up this chapter, communication plays an important part in negotiating behavior change. Studies show that people who lack confidence and/or are not willing to negotiate safer behavior have low confidence in persistently performing an act. Behavioral interventions such as education and training have been used to reduce risky behavior for decades. Even though the findings of these studies varied, most interventions sought to improve self-efficacy on condom use across the groups. The most effective intervention that stands out in this chapter is training for skills or self-efficacy. A clear relationship between skills and perceived risk are also shown in the chapter. In water treatment, well-designed training programs and materials increase selfefficacy in schools and homes. For a positive impact to be achieved, interventions must focus on increasing self-efficacy. DOI offers a standardized way of diffusion of ideas since it considers a number of factors that may influence change in diverse communities. Such ideas can be useful in the development of a specific, water-health education intervention developed for a local community. The next chapter describes the development of such a training program. 


\section{CHAPTER IV: INSTRUCTIONAL DESIGN}

The previous chapter explored the health communication theories of behavior change and their application in different societies. It also described previous investigations that have utilized Health Belief Model and Diffusion of innovations theories in various fields of research, demonstrating the usefulness of those theories in designing health communication strategies that might be used in a water health campaign. This chapter focuses on the instructional design models of learning, specifically, the Assessment, Design, Development, Implementation, and Evaluation model (ADDIE) that guided the study's education and training program.

\section{Learning and Instructional Design Technology}

The field of Learning and Instructional Design Technology (LIDT) has had a rapid development over the years. Training programs during World War II sparked the efforts to investigate efficient, systematic approaches to learning and instructional design. Twenty years later, the first instructional design was identified. As technology advanced, it paved way for new instructional technology and design processes that included the use of multimedia to facilitate effective learning (Reiser, 2017). The models were adopted by educational stakeholders and designers across multiple contexts (Gustafson \& Branch, 2002). As interest in training and development increased, identification of training procedures and terminologies became a concern, and thus standardization of instructional models occurred (Molenda, 2017), which triggered more interest in the field.

Recently, trainers have used instructional models to organize and design instructional processes to provide an outline for creation of instructional materials with the goal of providing

global health solutions through training (Merriënboer, 1997). Earlier instructional model such as Gagne's Conditions of Learning model postulates that different learners have different learning 
outcomes. Thus, they require different learning strategies that instructional design must consider for training development. Trainers must also understand and consider the training goals, prior to developing a cognitive functioning design, and implementation of instruction to create effective instructional materials (Gagne, 1985).

\section{ADDIE Model}

Florida State University partnered with the Department of Defense (Watson, 1981) to create the Assessment, Design, Development, Implementation, and Evaluation model (ADDIE), which further organizes Gagne's conditions of learning into five phases. The five phases constitute a framework for instructional design models that give insightful aspects for trainers during designing of training materials and approaches involved in training development (Bichelmeyer, 2005). And, therefore, ADDIE model guides the current study towards development, implementation, and evaluation of education and training program.

There are different schools of thought when it comes to ADDIE model as a stand-alone Decision Support Tool (DST). For instances, Gustafson and Branch (2002) argue that the ADDIE model provides a conceptual communication tool for visuals and procedures, and help manage instructions designs. On the contrary, Baturay (2008) argues that the ADDIE model is not a model but a platform/stage that other models follow in training development. These stages are discussed below.

Analysis stage. This is the first stage of the ADDIE model where data gathering and analysis of the problem takes place. In this sub-step, the designer evaluates the condition or situation to determine objectives that must be achieved in order to fix the problem. The objectives and goals of the program are intentionally assessed. The next sub-step is evaluation of the audiences who are participating in a program to confirm their knowledge, attitudes, and 
skills. Evaluation of the learners' skills is important for determining what skills must be trained in order to perform a certain task to bridge the performance gap. The timeline of the project and possible form of delivery based on the participants are considered. The last sub-step is to evaluate the environment under which the program will take place, for example, face-to-face or online platforms. It is critical that an in-depth and accurate needs assessment be done to increase the success of a program (Peterson, 2003).

Design stage. The design stage is the second stage of the ADDIE model. Primarily, the designer continues to conduct research and planning throughout this stage. It involves ranking and selection of the program to determine the strategies to achieve the objective of the program or job. Depending on conclusions that were made during the analysis phase following the needs assessment, the most effective intervention for delivery of objectives is selected (Seels \& Glasgow, 1998). This intervention can be education, training, or both, using different approaches. During this stage, learners' objectives, testing strategies, and items are developed. Since the learners' evaluation is done during the analysis stage, the content developed focuses on the skills that the learners must learn. The best instructional media and strategy are also selected. This stage helps in organizing the audience objectives and creating an implementation plan as discussed further below. The above procedure informs the basis of a good instructional design model.

Development stage. This phase requires more planning than research. During this stage, designers must refer to data collected during the analysis and design phases to develop materials for delivery of information. Instructional materials are created for the learners and trainers. Content can be text, graphics, PowerPoint slides, selection of videos or audio, or a combination of all in the program. In computer-based instructional learning, programmers build files and 
systems that support e-learning and create and update an execution plan. A pilot test then validates the effectiveness of the materials developed. After the pilot test, the trainer collects feedback and revises materials leading to the final production of the training.

Implementation stage. During this stage, the designers take an active role, unlike the previous phases. It involves material preparation and training of facilitators to deliver the instructions to the learners. The learners receive the instructions, their learning outcomes are assessed, and the feedback on the delivery of instructions is collected. Through this stage, the instructional designer monitors the delivery of the instructions from the learners and trainers to evaluate the effectiveness of the program.

Formative evaluation stage. This is the final stage. Evaluation is typically executed throughout all the above stages of ADDIE model to determine the effectiveness and accuracy of the materials developed for the instructional program (Bichelmeyer, 2005). Designers must measure the level to which the objectives are achieved. During this phase, decisions and activities incorporated in the instructional program are also evaluated and revised according to the feedback gathered from the learners during the pilot test. A final evaluation to sum up all the measures created and to determine the effectiveness of the instructions from the learners' perspectives is conducted. However, the summative evaluation does not measure learners' performance.

\section{Water Health Training in Kenya}

As a Research Fellow over the summer 2018 at Stonehouse Water Technologies LLC, the researcher chose the WaterPOD as one of the viable options for providing clean water in rural areas. The program idea was inspired by the researcher's experiences as a manager and employee in-charge of communication with the people at the Point of Grace Academy, Kenya, 
which currently has an old WaterPOD in place. During this time, the researcher discovered a communication and knowledge gap between the manufacturers and the users of the WaterPOD, leading to misinformation and dependence on simple technical operations that can be resolved by training the locals.

\section{Program Needs Analysis}

The ADDIE model mandates needs assessment in order to determine the best communication interventions for a public health crisis. To determine the knowledge, attitudes, and skill level of personnel at the Point of Grace and other counties, the researcher conducted informal phone interviews with administrators, student leaders, and a non-governmental executive. Specifically, the researcher's subjects included an administrator, student leaders, a school nurse, teachers and surrounding community leaders, and a well installer.

The researcher thematically analyzed the data collected from the interviews. Below are the themes of the brief informal interviews.

\section{Operational Competency}

WaterPOD users who have access to the internet and are able to comprehend online data reported less issues regarding maintenance of the product. However, the Point of Grace participants reported that they were not aware of the products' online data that can help improve its maintenance. Therefore, the participants needed to learn how the Internet of Things (IOT) works and how to read online data on their systems for better maintenance of the machines.

When asked why the school chose to discontinue using the WaterPOD, the administrator stated that they lacked knowledge on how to replace the filters. In addition, the filters' usual running time is about six months, whereas in Point of Grace, the filters lasted for less than two 
weeks. Investigations on why the filters running time was lower than usual revealed that there was poor maintenance, which led to wearing out of the filters.

\section{Self-Efficacy}

I observed how quick the users switched to drinking rain water every time the WaterPOD system were not working due to filter clogging, which could be avoided by proper maintenance. The users demonstrated their belief that rain water is safe for drinking, forgetting that waterharvesting materials as well as the storage facilities can contaminate the water. From the HBM perspective on efficacy, one could claim that the users could be having low self-efficacy regarding water health and operational-efficacy regarding the various types of water treatment systems and more importantly the WaterPOD. Individuals with strong self-efficacy beliefs develop stronger intentions to act or put more effort towards attaining their goals and persevere longer in the face of barriers (Bandura, 1991).

For participants with western affiliations who provided resources for their water treatment, water quality was equally important as quantity. A participant, who was a school administrator stated, "We have to be assured of good quality water, we must work towards minimizing the risks of supplying low quality and quantity of water." This could be as a result of knowledge on waterborne diseases which once led to the closure of the water treatment system due to cases of water-related illnesses among the students. This reaction was the opposite of those with no 'sponsor' affiliations who showed little knowledge and interest in using water purification systems. In addition, some of the participants did not prioritize water health over other aspects of health and wellbeing. Other participants expressed the desire to use water treatment systems only if they had more financial ability. 


\section{Knowledge on Waterborne Illnesses}

Few of the participants had knowledge of the common waterborne diseases such as diarrhea and typhoid. Additionally, many were unaware of the contaminants in their drinking water.

With the above analysis, the researcher concluded that one of the approaches to solve the problem was creating an education training program to facilitate knowledge transfer on the WaterPOD. The overall goal of this program was to provide ways to clean available water and sensitize the need for water filtration systems.

\section{Participants' Profile}

To accomplish this task and increase community participation, this program targets leaders of government, NGOs, students, churches, and common citizens. This program identified local government leaders due to their role in formulation and implementation of laws that protect water sources and policies that regulate drinking water treatment. Kenyans view religious and community leaders as the most influential and credible in transmitting health messages (Nyaga, 2016). Thus, from DOI perspective, it would be advisable to involve religious and community leaders in the design and implementation of health campaigns. Student leaders and parents are also invited for the training as they are opinion leaders in change according to DOI theory. For members of the public, the program identifies their contribution to sanitation and cross contamination of water sources.

\section{Training Objectives}

A multi-barrier approach was used to reach the overall desired objectives of the program. Training needs were determined based on the identified learners' needs and expectations of what should be covered during the program. The following quantifiable objectives were defined to provide training to cover the following topics: 
- General aspects of water, sanitation and health

- Sensitize the need for frequent water testing

- Provide information on filter purchasing and other available ways of water purification that are locally available

- Provide the instructional information and knowledge for peers to continuously engage in discussions that promote water health

- Provide a smart and viable technology solution, the WaterPOD, to eliminate the presence of disease-causing organisms that cause ill-health and reduce contaminants to an acceptable level at Point of Grace Academy.

\section{Program Design}

The researcher designed the program into various parts: sessions, WaterPOD installation manual, and PowerPoint presentation' content that comprised of statistics, pictures, text, and graphics.

Training program. Training preparation and implementation of the program was done according to the training needs assessment analysis. The training was carried out in four different locations: Samuli, Oltinka, Kisumu, and Nairobi. The schedule is shown in Table 2. Table 2

Proposed Program General Schedule

\begin{tabular}{|l|l|l|}
\hline Location & Time (East African) & Activity \\
\hline Samuli, Oltinka, & $11: 50 \mathrm{PM} \mathrm{-12:05} \mathrm{PM}$ & Time 1 survey \\
Nairobi, Kasarani & & \\
\hline
\end{tabular}

Table Continues 


\begin{tabular}{|l|l|l|}
\hline Location & Time (East African) & Activity \\
\hline & $12: 05 \mathrm{PM}-12: 15 \mathrm{PM}$ & Introduction \\
\hline & $12: 15 \mathrm{PM}-12: 35 \mathrm{PM}$ & References \\
\hline & & Water Contamination/Sources \\
\hline & $12: 35 \mathrm{PM}-12: 40 \mathrm{PM}$ & Discussion break \\
\hline & $12: 40 \mathrm{PM}-1: 00 \mathrm{PM}$ & Health concerns \\
\hline & & Water treatment methods \\
\hline & $1: 00 \mathrm{PM}-1: 15 \mathrm{PM}$ & Time 2 survey \\
\hline & & \\
\hline
\end{tabular}

The researcher designed the Kisumu session differently since the participants received the WaterPOD water treatment system unlike other participants. Therefore, the program entirely focused on the WaterPOD and its maintenance as shown in Table 3.

Table 3

Training Kisumu Program Schedule.

\begin{tabular}{|l|l|}
\hline Location & Activity \\
\hline Kisumu & Training on WaterPOD \\
\hline & Hands-on work/ Practical \\
\hline
\end{tabular}

Sessions. The same content was presented throughout the sessions with minimum changes depending on the audience (See details in the implementation phase). The training program involved four sessions, which took place in Technical University of Kenya, Kasarani, FPFC Samuli Church, Oltinka Baptist church, and Kisumu (POG). These sessions were about 60-75 
minutes each. With the knowledge that learners have different learning styles, the researcher used manuals, pictures, and graphics to complement text dominated presentations.

WaterPOD manual. The content of this manual included pictures that demonstrated how day-to-day task maintenance is performed. The installation manual was developed in English to provide its users with information on the product. As part of this task, the researcher also intends to translate this manual to Swahili to help more users in operate this product effectively in Swahili speaking nations. Swahili is a Bantu language widely spoken in East African countries.

PowerPoint presentation. A PowerPoint presentation was created to help facilitate the training sessions. This PowerPoint composed of the following:

Statistics. To establish credibility, demographics and statistics of water contaminants according to National Environmental Management Association (Kenya), World Health Organization, Water Organization, and United Nations Water were highlighted. The trainer shared her experiences and achievements on water health.

Pictures and text. Visuals enhance presentations, retention, and comprehension of concepts such as organic and non-organic, industrial, and sewage contamination. This would benefit the participants with low education level or the illiterate (Arbuckle, 2004). Additionally, the pictures were carefully selected with diversity and cultural sensitivity in mind as some of the program locations were churches and conservative societies. Pictures intended to evoke fear appeared in appropriate slides on health issues related to water, such as leptospirosis and dysentery.

Graphics. Graphics illustrated the WaterPOD's maintenance process to the users.

\section{Program Development}

The training approach used relied upon adult learning theory, which involved a variety of effective learning methodologies such as demonstrations, discussions, and brainstorming (Khalil 
\& Elkhider, 2016). Taking into account the information on water health, trainer experiences, participants' profile, and themes, the trainer used the following methodology:

Discussion. Since the training was open for all participants, brief guided discussions conveyed various important themes, such as waterborne diseases and individual contribution to water contamination.

Interactivity. This approach was most suitable for the Nairobi session since most of the trainees were college students who live in the city. The trainees had knowledge about some of the training themes and required less guidance throughout the discussions, unlike the trainees in Samuli and Oltinka sessions, who required discussion prompts and more guidance.

Trainer's practical examples. Considering that the trainer was experienced and exceptionally acquainted with the training topic and the WaterPOD, real life situations witnessed by the trainer helped in elaborating themes and to invite trainees' participation.

Hands-on work. After the presentation and explanations on WaterPOD maintenance, the participants had an opportunity to do some practice on the system.

Assessments. In order to evaluate effectiveness of the training, the researcher created a brief open- and closed-ended Time 1 and Time 2 surveys. This survey acted as a tool to evaluate the success of the program and assess the participants' knowledge of water health before and after the training. To gather valid participants' impressions and opinions, it was explained to them that the surveys were completely anonymous and confidential for those who took printed copies of it. Observations were also used to observe operational knowledge transfer from the trainer to the trainees in Kisumu, since the community received the WaterPOD water treatment system. 


\section{Conclusion}

This chapter presents a detailed description of ADDIE model of instructional design and its applications in the training discipline. Later in the chapter, the researcher explicated how the model was used to develop the Kenyan training program and introduced the first three steps of ADDIE, which is, Assessment, Design, and Development. These steps are important for the effectiveness of the next steps of the model. The next chapter explains the last two steps of the ADDIE model; Implementation and Evaluation. 


\section{CHAPTER V: PROGRAM IMPLEMENTATION AND EVALUATION}

Implementation of a training program is critical in obtaining the intended goals and outcomes. Program evaluation deliberates the success of a training program. It helps identify the aspects in the training procedures and programs that were beneficial and highlights areas for improvement. Recent studies cited in the previous chapter consistently note that the most effective evaluation is done throughout a training session and not only at the end of a training program. Thus, the researcher composed evaluation plans at the beginning of each session and results used to modify future training. This chapter explains how the Kenyan training program was implemented and evaluated; before, during, and after the water health education and training program.

\section{Implementation Travel}

A few weeks from the Fall semester final week, the researcher was notified about possible Christian youth gathering taking place within the time of her scheduled trip. The researcher travelled from the United States to Kenya to implement the training program. Since the trip was sponsored, the researcher did not face any challenges getting to O'Hare International Airport, Chicago. The flight boarding started and minutes later the take-off to Ethiopia began. The trip took 15 hours to Ethiopia and 2 hours to Nairobi excluding layovers. In the latter flight, the researcher persistently observed individual and group interactions for cues on any change of behavior that could affect the research. After landing, the researcher was anxious to see what the country looked like two and half years after her departure and interacted with a few people at the airport in a bid to identify effective ways to engage with the participants. 


\section{Actual Program Implementation}

The training was open to all individuals including children as the studies and DOI note that children can be opinion leaders in water purification promotion in households where parents are uneducated. There was no registration required as all the training sessions occurred between other programs, and there was no compensation offered to participants. However, the minimum age for eligibility to participate in the study's survey was 18 years.

Training implementation consisted of two phases: The preparatory phase and the actual training.

The preparatory phase. This involved a pilot survey test with five Kenyan college students to ensure the study's data collection process was feasible. Second, the trainer trained a research assistant to help throughout the training process. This involved articulating plans and expectations; familiarizing the research assistant with PowerPoint, the trainer's notes and research, and survey taking; and answering questions regarding the themes of the training. The trainer briefed the research assistant on aspects of participants' reactions and interactions to facilitate effective observations. Third, prior to the actual training, the trainer attended several sessions of the religious gatherings to acquaint herself with participants and the location of the upcoming training.

Actual training phase. The actual training involved three sections: Time 1 survey, Presentation, and Time 2 Survey. Time 1 and 2 surveys involved distribution of the survey and helping the participants with questions regarding the survey. The second part focused on introducing the trainees to the references which the trainer used to gather the information that they were to learn and the presentation. 


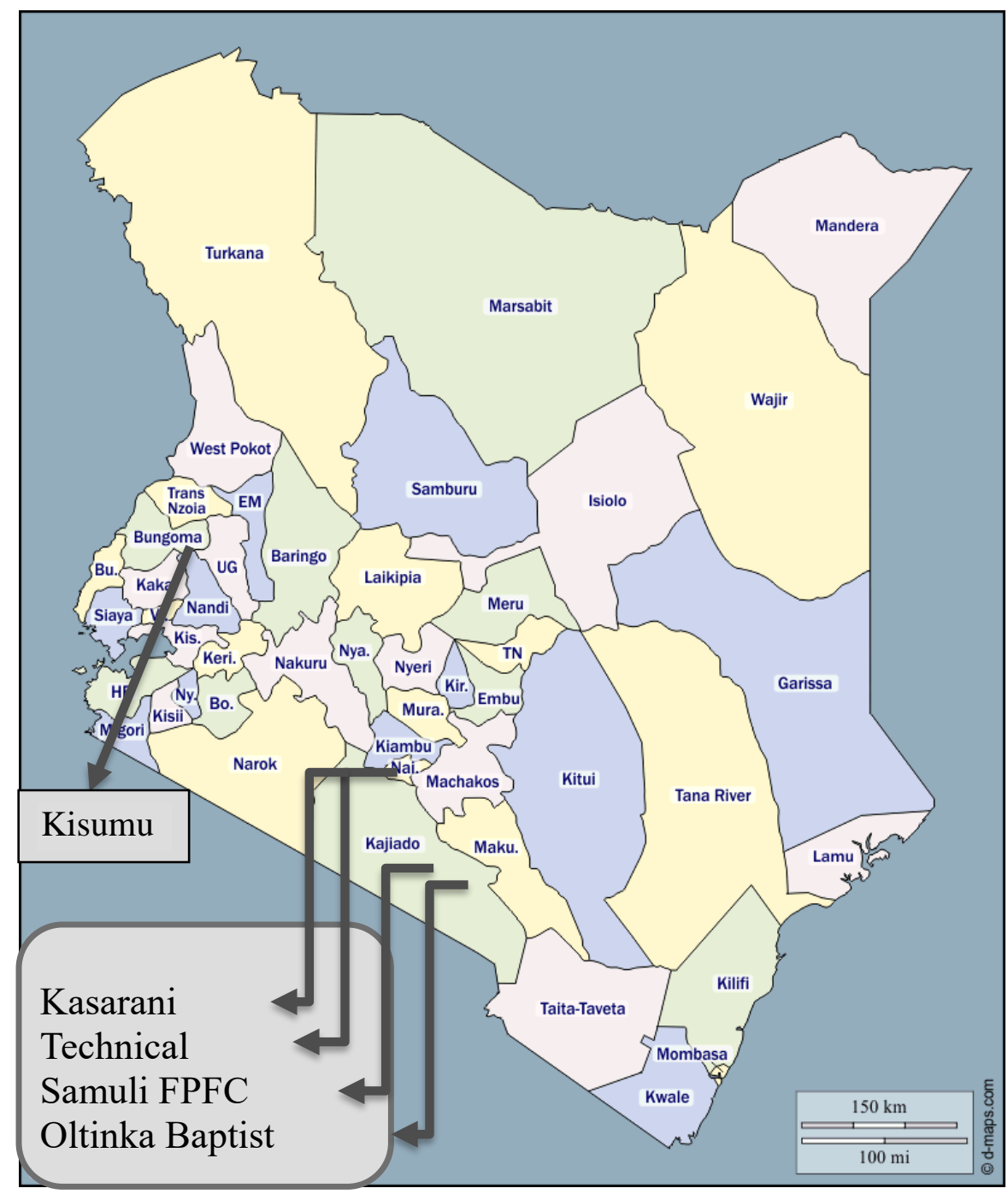

Adapted from: https://d-maps.com/carte.php?num_car=35032\&lang=en

Figure 8. Map of Kenya showing training locations.

\section{Samuli}

One of the training sessions took place at FPFC Samuli church. The church was under construction and it had tents on one of its corners where the congregation gathers for their service. The church was holding a youth seminar. The trainer attended the last evening session to interact and catch up with them, since most of attendees of the three-day youth seminar were her childhood friends and their siblings. Set up and seat arrangement were also done ahead of time. During these interactions, the trainer realized that a few individuals in the church did not understand or speak the Maasai. Maasai language is an Eastern Nilotic language spoken in 
Southern Kenya and Northern Tanzania by the Maasai tribe, which is about 800,000 people. Therefore, English and Swahili languages were used throughout this session as indicated in Table 4.

Table 4

Training Program Samuli Schedule

\begin{tabular}{|l|l|l|l|}
\hline Location & Language of Training & Time (East African) & Activity \\
\hline Samuli & $\begin{array}{l}\text { Swahili } \\
\text { English }\end{array}$ & $5: 50$ PM -6:00 PM & Time 1 survey \\
\hline & & $6: 00$ PM -6:05 PM & Introduction \\
\hline & & $6: 05$ PM -6:15 PM & References \\
\hline & & $6: 15$ PM -6:35 PM & Water \\
\hline & & $6: 35$ PM -6:40 PM & Discussion break \\
\hline & & $6: 40$ PM -7:00 PM & Health concerns \\
\hline & & & Water treatment methods/ \\
\hline & & $7: 00$ PM -7:15 PM & Time 2 survey \\
\hline
\end{tabular}

The trainees included students slightly under the age of eighteen. The session began with a worship session and a couple of Bible verses read by the youth chair director, who later handed the podium over to the researcher. To facilitate a smooth transition from the religious session to the water health session, the researcher introduced herself, gave an overview of the program, and 
explained why the program targeted the attending participants. The researcher provided a link to start the presentation and handed out hard copies of Time 1 survey and pencils to those without internet or smart phones who were at least 18 years of age. The data collection (survey) process was smooth since all the participants were literate. Later, the participants were asked to discuss and write down in pairs what type of water they think is safe for drinking. Facilitation techniques that were used throughout this presentation were direct explanation of various water contaminants dominated the session as most of trainees lacked knowledge of their water sources and health concerns. This involves use of concrete example of diseases associated with consumption of contaminated water. For example, reproductive system damage, kidney failure, heart diseases, leptospirosis, and dysentery. Finally, during the sessions, participants were selected using questions that measured their awareness of different topics and/themes such as water contaminants and their short- and long-term effects on health. For example, the participants were asked to choose the type of water (tap, well, and bottled) that they thought was safe for drinking. The participants also gave brief explanations on their choices. Later, the participants were asked the same questions after training to examine whether their opinion changed at the end of the session. At the end of the training, trainees participated in Time 2 survey.

\section{Oltinka Baptist Church}

The second location of training was Oltinka Baptist Church (OBC) in Oltinka. OBC is the headquarters of the Poka-Kinyewa Baptist churches. The church held a four-day youth seminar that was attended by most of the youths within the divisions. As part of the pre-training preparation, the trainer attended the first and second day of the seminar. During these two days, the trainer observed diverse groups of people from different parts of Poka-Kinyewa division. 
Many groups varied in terms of knowledge on water purification due to the remoteness of some villages. For example, some participants lacked knowledge on the basic types of water treatment methods leading to modification of the PowerPoint to address available water purification systems such as water boiling. The training session took place in the afternoon of the third day. Table 5 shows the training session schedule.

Table 5

Training Program Oltinka Schedule

\begin{tabular}{|c|c|c|c|}
\hline Location & Language of Training & Time (East African) & Activity \\
\hline \multirow[t]{9}{*}{ Oltinka } & $\begin{array}{l}\text { Swahili } \\
\text { English } \\
\text { Maasai }\end{array}$ & 11:50 AM -12:00 PM & $\begin{array}{l}\text { Pairing up educated 16-17 } \\
\text { years olds } \\
\text { with illiterate adult }\end{array}$ \\
\hline & & 12:00 PM -12:05 PM & Introduction \\
\hline & & 12:05 PM -12:15 PM & Time 1 survey \\
\hline & & 12:15 PM -12:35 PM & References \\
\hline & & & $\begin{array}{l}\text { Water } \\
\text { Contamination/Sources }\end{array}$ \\
\hline & & 12:35 PM -12:40 PM & Discussion break \\
\hline & & 12:40 PM -1:00 PM & Health concerns \\
\hline & & & $\begin{array}{l}\text { Water treatment } \\
\text { methods/WaterPOD }\end{array}$ \\
\hline & & 1:00 PM -1:15PM & Time 2 survey \\
\hline
\end{tabular}


After transition to the training session, the trainees took Time 1 survey. Seventy-five trainees attended the whole training session including young teens and the elderly. A greater percentage of the elderly were illiterate and, therefore, Swahili and Maasai were used throughout the sessions. The session lasted for 45 minutes with a discussion break in between the sessions. Nairobi

The third session of the training took place in Nairobi. Nairobi is the capital city of Kenya and home to many national and international universities. Specifically, this session took place in Technical University of Kenya, which is one of the best technical universities in the country. This university admits students from different parts of Kenya. Another session took place in a residence hall in Kasarani area (see schedule in Table 6). The trainees comprised of holders of diplomas, degree, and masters. Further, continuing students also attended the full training session. Some opted out of the training session upon introduction of the training subject. Table 6

Training Program Nairobi Schedule

\begin{tabular}{|l|l|l|l|}
\hline Location & Language of Training & Time ( East African) & Activity \\
\hline Nairobi/ & English & $11: 50$ AM-12:00 PM & Time 1 survey \\
\hline & Swahili & $12: 00 \mathrm{PM}-12: 05 \mathrm{PM}$ & Introduction \\
\hline & & $12: 05 \mathrm{PM}-12: 15 \mathrm{PM}$ & References \\
\hline & & $12: 15 \mathrm{PM}-12: 35 \mathrm{PM}$ & Water Contamination/Sources \\
\hline & & $12: 35 \mathrm{PM}-12: 40 \mathrm{PM}$ & Discussion break \\
\hline
\end{tabular}

Table Continues 


\begin{tabular}{|l|l|l|l|}
\hline Location & Language of Training & Time ( East African) & Activity \\
\hline & & $12: 40 \mathrm{PM}-1: 00 \mathrm{PM}$ & Health concerns \\
\hline & & & $\begin{array}{l}\text { Water treatment } \\
\text { methods/WaterPOD }\end{array}$ \\
\hline & & $1: 00 \mathrm{PM}-1: 15 \mathrm{PM}$ & Time 2 survey \\
\hline & & $1: 15 \mathrm{PM}-1: 30 \mathrm{PM}$ & Post- training discussions \\
\hline
\end{tabular}

\section{Kisumu}

Since the participants in Kisumu received the WaterPOD water treatment system, the training program entirely focused on the WaterPOD functionalities and its maintenance. However, there were no changes made to the Kisumu schedule (Table 7). Table 7

Training Program Kisumu Schedule

\begin{tabular}{|l|l|l|}
\hline Location & Language & Activity \\
\hline Kisumu & English & Training on WaterPOD \\
\hline & Swahili & Hands on/ Practical \\
\hline
\end{tabular}

\section{Program Evaluation}

In chapter 4, the ADDIE model proposes identification of program evaluation type(s)

before the training. The current program evaluation methodologies included a survey and observation. The two methods measured process and outcome of the training program. The evaluation of this program had two major components. The first component was a comparison of 
individuals' beliefs and attitudes before and after the program. The trainer accomplished this through a brief Time 1 and Time 2 survey on water health and purification systems. The second component was a summative evaluation of attendees' perception of the program.

\section{Participants Profile}

The sample consisted of individuals with a mean age of 24.86 years $(S D=7.36)$, ranging from 18 to 60 years. The total sample size comprised of 106 participants. However, five participants who were late for Time 1 survey were excluded from the sample. Therefore, 101 participants took part in the study. Of the sample, 49 (48.5\%) participants were male, $42(41.6 \%)$ were female, and 10 (9.9\%) participants did not indicate their sex. The participants' level of education was as follows: 38 (41.8\%) graduates/ undergraduates, 35 (38.5\%) high school level, 2 (2.2\%) primary school level $(12.7 \%)$ and $2(2.2 \%)$ never attended school . The counties of residence that the participants self-reported were as follows: 43 (42.6\%) Kajiado, 30 (29.9\%) Nairobi, 3 (3.0\%) Nakuru, 2 (2.0\%) Nanyuki, 2 (2.0\%) Kiambu, 2 (2.0\%) Makueni, 1 (1.0\%) Mbale, 1 (1.0\%) Mombasa, 1 (1.0\%) Kakamega, 1(1.0\%) Laikipia, 1 (1.0\%) Naivasha, 1 (1.0\%) Elgeyo Marakwet, $1(1.0 \%)$ Nyandarua, and $1(1.0 \%)$ Nyeri.

The participants were asked to indicate their water source, and their responses were as follows: 42 (44.2\%) municipal, 19 (20\%) well, 11 (11.6\%) river, 8 (8.4\%) other, 8 (8.4\%) dam, 4 (4.2\%) did not know, $2(2.0 \%)$ oceans, and $1(1 \%)$ lake. Further, the majority of the participants noted that the government was responsible for their water 52 (55\%), followed by 17 (18.1\%) private organizations, $12(15.8 \%)$ nonprofit organizations, 7 (7.4\%) myself/individual, and 6 (6.4\%) did not know. In terms of water usage, the participants indicated that they mostly used their water for domestic purposes: $77(82.8 \%)$ used water for domestic use, then $6(6.5 \%)$ used 
water for their livestock, 3 (3.2\%) used water for commercials gains, 5 (5.4\%) irrigation, and 2 $(2.2 \%)$ recreational use.

\section{Procedure}

Prior to the training program kick off, the researcher explicated to the participants that the research was voluntary and that they could withdraw their participation any time without any consequences. Later, the researcher invited the participants to complete an online survey. The willing participants received a link to the survey, which was administered through the Illinois State University's Qualtrics software. Those whose who did not have electronic devices received a paper and pencil survey, the results of which the researcher later entered into Qualtrics survey site. Those who agreed to participate took the first section (Time 1) of the survey items that measured their knowledge of their water sources, responsible authorities, and water testing. Additionally, Time 1 survey comprised of questions, which measured the participants' motivation and willingness to put individual effort toward water sources protection and water health before participating in the training program.

At the end of the program, the researcher invited the participants to take part in Time 2, which measured their knowledge of their water sources, responsible authorities, and water testing after participating in the program. The minimum age for eligibility to participate in the study was 18 years, and only those participants who took Time 1 survey were allowed to take Time 2 survey. This was enabled by handing out copies of the survey and projecting the link to survey on the trainer's PowerPoint to the participants present.

\section{Measures}

The researcher developed scales purposely for this research. The responses were measured using Likert response options ranging from 1 (strongly disagree) to 5 (strongly agree); 
yes or no or maybe. A list of answers was provided for participants to select what applied to them and text boxes for open ended questions were provided. The following section describes the specific measures.

\section{Time 1 Survey}

Water source, usage, responsibility, and related challenges. The participants' knowledge on water testing types, procedures, and places were deliberated using items scale. "Where do you get your water from?" "Who is responsible for oversight of water quality in your local area?" "Who takes care of water in your household?" "What do you mostly use your water for?" and "What are the challenges of getting this water from the source?"

Water quality, testing, and information. The researcher developed item scales to establish whether the participants' had knowledge on their drinking water quality. Some of the items read, "Pick the quality of the water you use." "Does your water have any smell?" "I perform sensory testing," "Do you test your water before use?" "I do lab testing for my water," "How frequent do you test your water?" and "For the last one year, have you received any information about your water quality from your water provider?"

Perceived susceptibility. The researcher composed items to measure the participants' perceived susceptibility before the training. The questions included "I believe that my water is safe for drinking," "I believe that my water is NOT safe for drinking, "Do you test your water before use? If Yes; Why? If No; Why?" "I treat my water before use," "Contaminated water will make me sick," "Water quality is the least of my worries," and "Water contamination is not a problem where I live," and "I believe that groundwater may not be safe to drink." Some of these items were recorded. The reliability test produced a Cronbach's alpha of .79, which is a respectable reliability. 
Self-efficacy. A self-efficacy scale consisted of 4-items scale. The scale was developed to unearth more information about the participants' confidence in performing behaviors that promote water health. This was achieved by asking questions relating to various habits and acts that can be used to assess the participants' wellness intentions. The items in this scale included "I am confident that I can do something to seek safe drinking water," "I am going to change my actions that contribute to water pollution, and "I support laws that protect drinking water and its sources."

Knowledge on water contaminants and diseases. This measure included items to measure participants' knowledge of diseases before the training. The item was "Which of the following water health issues are you aware of?" Furthermore, the researcher composed items to unearth participants' knowledge of contaminants prior to the training. Responses to the items were measured with a list of water related illnesses and contaminants.

Demographic questions. The last section of the survey comprised of four items that asked participants about their demographics. These included, "What county do you live in?" "What is your gender?" "What is your highest level of education?" "Indicate your age." Participants recorded their responses using text boxes, for the age question, participants used a number slider with which they selected the year of their age. For the gender item, the researcher included the male and female options, but with no transgender option due to cultural sensitivity.

\section{Time 2 Survey}

Time 2 Survey comprised of questions that invited participants' opinions and reactions to the training program that measured the participants' motivation and willingness to put individual effort toward water sources protection and water health after the training. Additionally, some questions on susceptibility, self-efficacy, knowledge of contaminants, and awareness of 
waterborne diseases from Time 1 survey were repeated in Time 2 survey. The researcher believed it was imperative to include these questions in order compare participants' perception based on the mentioned items before and after the training to ascertain the success of the training.

Perception of training. The first section of Time 2 survey focused on the content of the program that the participant found to be beneficial. The first item explored participants' benefits from the training using an open-ended question--“What did you find most useful about today's training?" as well as closed-ended questions: "How much of the content of this training did you already know?" and "I feel my attitude towards water consumption has changed as a result of this training," as well as a Likert scale to measure other benefits of the training such as "it stimulated my thinking," "it motivated me to do something to improve my water health," and "I feel my attitude towards water consumption has changed as a result of this training."

WaterPOD and its maintenance. The researcher developed a 5-item scale that sought to measure the participants' knowledge on the newly introduced water purification system. These items included, "What did you learn about the water purification systems and their maintenance?" "What are some of the filter's name that you remember?" "Do you feel this is a product you can use?" "I feel this is a product I can adopt," and "I feel like this product meets my needs,"

The final part of Time 2 survey requested participants to rate the trainer's facilitation skills, strengths, weaknesses, and knowledge on content. The researcher did not include demographic items in Time 2 survey since only those participants who took the Time 1 and attended the full session were allowed to take this survey. 


\section{Data Analysis}

This study used different data analysis methods to evaluate the success of the program. A one-sample $t$ test was conducted to determine the participants' perception of the training. First, descriptive were also run to understand participants' characteristics and reliability tests for the scales since the researcher developed the scale items for the program's evaluation.

Second, four different independent-samples $t$-tests revealed the extent to which the training programs were met, specifically an independent-samples $t$-tests to investigate participants' knowledge on water contaminants, waterborne diseases, self-efficacy, and perceived susceptibility before and after the training. The trainer did not track individual participant's responses; therefore, the most suitable test was paired independent samples $t$ test.

Third, four bivariate correlation tests determined the strength of association and the direction of the relationship between participants' perceived susceptibility to waterborne diseases, self-efficacy, and knowledge of waterborne diseases and willingness to purchase water purification systems.

Finally, a thematic analysis investigated the open-ended responses and observations notes to identify patterns and aspects around water health and the training program.

\section{Results}

This section presents the qualitative and quantitative results of the program. The statistical analysis performed were descriptive statistics to describe the participants, bivariate correlations, one sample $t$-test, and independent paired samples $t$-tests. The analysis facilitated evaluation of the training program. The trainer's performance results were not included in this section but the researcher used the findings to provide future recommendations for first time 
trainers in the succeeding chapter and also plans to use the participants' feedback to improve her facilitation skills.

\section{Perceived Benefits}

A one sample $t$ test was also used to determine the general participants' perception of the training. The Participants indicated the benefits that they received from the training program based on the items in Table 8 . 
Table 8

Perceived Training Benefits

\begin{tabular}{|c|c|c|}
\hline Perceived Benefit & Mean & SD \\
\hline Thinking Stimulation & 4.28 & .83 \\
\hline Motivation & 4.10 & .93 \\
\hline Attitude change & 4.37 & .84 \\
\hline Self-efficacy & 4.33 & .82 \\
\hline
\end{tabular}

Themes on Important Lessons learned from the Training

To measure the extent to which the training benefited the participants, the trainers developed categories of perceived benefits from the qualitative data. These categories included waterborne diseases, water hygiene, treatment methods and procedures, and the WaterPOD. However, none of the participants' excerpts showed any drawbacks of the training program. Below is a brief discussion of the categories.

\section{Water Quality}

Many participants noted water quality knowledge as a benefit that they acquired from the training. Some of the participants' excerpts read:

- Water quality is very important since it impacts our health

- Taught me the effect of contaminated/ untreated water

- Provided valuable information about water quality 
- Gave insight on harmful water and sources

Sanitation. Literature on water health depicts that an environment that lacks proper toilet or human waste disposal and clean water is bound to have high causes of deadly diseases. It was important that the participants learn the relationship between sanitation and water health. The participants amplified this theme on their responses:

- It helped me learn sanitation and its contribution to poor water health

- It provided general education on water health and sanitation

Waterborne illnesses. Participants indicated that the training facilitated learning on harmful infectious agents that occur in unclean water that cause illnesses. Some of the responses included:

- It helped me know what causes diseases

- I gained knowledge on methods of controlling water diseases

- It helped identify many other diseases caused by water

- I gained knowledge on how I will keep my water safe for drinking

According to the above responses, the training goal to inform the participants that source, storage, sanitary measures such as toilet, and education of waterborne diseases influences the attainment of clean drinking water.

\section{Water Treatment Procedures and Methods}

Some respondents revealed that the training enhanced their learning on water purification systems and procedures. Below are some of the quotes from the participants:

- Gave me easier ways to treat water

- Provided valuable knowledge on water purification

- It made the process of water treatment easy 
- It made me to be conversant on water treatment process

- It enlightened and educated about water health

\section{WaterPOD in Water Treatment}

Some participants asserted that, through this training program, they became aware of the WaterPOD and its functionalities. Below are some of the participants' reactions:

- It helps purify drinking water free virus and bacteria

- It has stages of purifying

- Reduces nearly whole water contaminants

On the same note, participants gained knowledge on the WaterPOD maintenance. Some of the participants wrote:

- Dumping the water always when the pod is not running

- The filters can be cleaned using a special chemical

- Filters need to be cleaned regularly

Additionally, as revealed by the quantitative results on the WaterPOD, participants indicated that the product meet their water quality needs and were willing to purchase the WaterPOD.

\section{Summary of Relevant Time 1 and 2 Results}

As noted earlier that Time 1 and 2 survey contained a few similar questions that measured individuals' knowledge on water health before and after the training, the next section presents results gathered from those specific questions, then results from the trainer's observations.

\section{Knowledge Acquired}

Waterborne diseases. An independent samples t-test was performed to determine if participants' knowledge on waterborne diseases would differ before and after the training. 
Levene`s test for variance was significant $(F=.115, p=.000)$, therefore, equality of variance cannot be assumed. Significant results emerged, $t(198)=-9.95, p=.000$. Scores of participants after the training $(\mathrm{M}=6.04, S D=2.09)$ statistically differ from the responses collected before the training $(\mathrm{M}=3.00, S D=2.23)$. Specifically, the participants' knowledge on waterborne diseases doubled after the training.

Water contaminants. To test for knowledge of contaminants, a total for each participant was calculated out of the total number of the nine potential contaminants that were listed in the survey. An independent samples t-test was performed to determine if participants' knowledge on water contaminants would differ before and after the training. Levene`s test for variance was significant $(F=.115, p=.000)$, therefore, equality of variance cannot be assumed. Significant results emerged, $t(198)=-9.95, p=.000$. Scores of participants after the training $(\mathrm{M}=5.22, S D$ $=1.42)$ statistically differ from the responses collected before the training $(\mathrm{M}=2.82, S D=1.40)$. The participants' knowledge on water contaminants diseases increased significantly after the training.

\section{Susceptibility}

An independent samples t-test was conducted to determine if participants' susceptibility would differ before and after the training. Levene`s test for variance was significant ( $F=3.21, p$ $=.000)$, therefore, equality of variance cannot be assumed. Significant results emerged, $t(155)=$ $-17.08, p=.000$. Scores of participants after the training $(\mathrm{M}=17.31, S D=3.89)$ statistically differ from the responses collected before the training $(\mathrm{M}=10.31, S D=2.04)$.

Specifically, the participants perceived that they are at risk of getting waterborne disease after the training. 
Bivariate correlation determined whether participants' perceived susceptibility to waterborne diseases would predict with their likelihood of purchasing water purification systems. The results indicated that there was a positive strong relationship between perceived susceptibility and the likelihood to purchase water purification systems or at least pay for water purification, $r(93)=.66, \mathrm{p}<.001$. That is, when individuals perceived that they are at risk of waterborne diseases the more likely they are to use water purification systems or products.

\section{Self-Efficacy}

An independent samples t-test was performed to determine if participants' self-efficacy would differ before and after the training. Levene`s test for variance was significant $(F=1.56, p$ $=.01)$; therefore, equality of variance cannot be assumed. Significant results emerged, $t(142)=-$ $21.10, p=.000,95 \% \mathrm{CI}[-14.76,-12.23]$. Scores of participants after the training $(\mathrm{M}=34.56, S D$ $=4.27)$ statistically differ from the responses collected before the training $(\mathrm{M}=21.34, S D=3.2)$. Explicitly, the participants gained confidence in their abilities in using water purification systems to avoid waterborne diseases.

A bivariate correlation test was conducted to determine if participants' self-efficacy to pursue actions to avoid waterborne diseases would predict their likelihood of purchasing water purification systems. The results indicated that there was a positive strong relationship between perceived self-efficacy and the likelihood to purchase water purification systems or at least pay for water purification, $r(89)=.876, \mathrm{p}<.001$. Precisely, individuals' who are confident in their ability to adopt actions such as use of water purification and supporting laws to prevent waterborne disease are willing to purchase water purification systems. 


\section{Observation Results}

\section{Hands-on Work}

Throughout the sessions, the participants showed interest and curiosity on water health and, most importantly, the WaterPOD. Previously, while working on the WaterPOD project and managing the Kenya projects for Stonehouse, the schools' administrators in Kenya were not able

to differentiate the WaterPOD's filters by name and instead distinguished them by color and size. During the Kisumu session, the trainer demonstrated WaterPOD purification process, maintenance, and installation of the new parts as the research assistant observed. This involved depressurizing the system and dumping the water every day after use to prevent bacterial growth on the filters. Then, attendees followed the steps provided to complete the tasks by themselves. After interacting with the WaterPOD, the participants became confident in identifying filters by names and operating the POD compared to when they were receiving instructions on email or phone. This finding was consistent with Burke et al. (2006), who state that people learn better through hands-on training (see also Holman, Pavlica, \& Thorpe, 1997). Therefore, participants endorsed face-to-face training coupled with hands-on work for technology adoption.

\section{Technical University of Kenya Post-training Discussion}

College students requested a post- training sessions after the completion of the training. This session offered a deep understanding of the water health, the WaterPOD water purification cycle, maintenance, and filter composition. Questions regarding wastewater treatment plants such as Nairobi city Sewage Company, metallic pipes, and types of water dominated the session. The participants were highly motivated to be ambassadors of water health moving forward and to create awareness on water heath good practices. It is interesting that a couple of days later, firstyear students who had participated in the training for this study had a lecture on health education, 
which introduced water sources, pollution, and treatment. This shows emerging efforts to promote water health in Kenyan universities.

\section{Conclusion}

This chapter presented training evaluation results. The overall program evaluation results showed significant improvement in both knowledge and skills of the participants after the training. All participants actively attended all the training sessions with curiosity and participated in the discussions. Time 2 responses revealed promising attitude change towards water health and source protection. Further, the results of the last question that looked on whether or not participants will recommend the training program in the future showed that participants were willing to learn to improve not only their own water health but also others' health.

Throughout the program evaluation, the researcher noted the extent to which the training's envisaged objectives were met, the relevance and usefulness of the training's content, the appropriateness of the training methods used, usefulness of the materials used, and the logistics of the training program. The next chapter explores programs' success contributors, recommendations for future trainings, and suggestions for future training changes. 


\section{CHAPTER VI: DISCUSIONS/ RECOMMENDATIONS}

The preceding chapter focused on the evaluation process of the training program. The results revealed that the goals of the training program were met. This chapter highlights the contributors of the training program success, recommendations for first-time trainers, and program changes to improve the training.

\section{Contributors of Program Success}

\section{Setting Up}

For trainers planning to conduct training in other countries, setting up on site at least a week prior to the training program is important for the success of the training program. This is to make sure there is enough time to overcome any challenges such as equipment-related problems that might prevent trainers from conducting the intended training program and cause panic if discovered right after the training kick off. For example, during the pre-preparation phase, the trainer encountered challenges with the compatibility of one of the projectors with the format of the PowerPoint. This required a format change of the files which, in turn, affected the quality of the graphics leading to acquisition of another projector. Fortunately, the researcher had enough time to borrow another projector. In addition, trainers should also know the specifications and the outlook of the deck slides that will be used across different technologies (Wrench, Johnson, $\&$ Citera, 2015).

\section{Introduce 'Preparation' into ADDIE (ADDPIE)}

Preparation for training implementation is imperative. According to Biech (2016), preparation to training starts with understanding the reason for doing the training, the content to prepare for, and the general and specific objectives of the program. In the training for this study, preparation helped the trainer to pace herself efficiently. It also helped her to familiarize and 
revisit some particular themes that perfected her facilitation and provided a smooth transition throughout the training. Even though preparation is time-consuming, it plays a great role in a training program's success, which can be determined at the end of the actual training. The advantages of preparation that the trainer experienced include time saving when answering participants' questions and understanding vital training concepts. Emerging trainers should take sufficient time preparing for their training. During this time, trainers can further focus on ways to increases their facilitation on hands-on work and authenticity throughout the training.

Hands-on work. Informal hands-on work provided the participants the opportunity to practice their newly acquired skills. Hands-on work made learning specific tasks easier and enhanced transfer of technical knowledge to the participants. For the hands-on work training, the trainer spent about two months learning the functionalities of the WaterPOD and trained to teach others how to operate it and conduct day to day maintenance.

Authenticity and mindfulness. Authenticity is one aspect that increases effectiveness and efficiency of a training program. Even though authenticity of the trainer depends on the participants' perceptions, for the most part, the trainer can achieve authenticity by being organized, consistent, and compassionate while dealing with participants throughout the training.

\section{Multitasking}

Encoding of information requires more attention than retrieval of information.

Multitasking on the part of trainees interferes with encoding of information (Foerde, Knowlton, \& Poldrack, 2006). That is, lack of attention negatively affects learning and information retention. Multitasking not only influences the quality of memory but also its quantity. Therefore, for successful training, the trainer must work against the trainees multitasking to ensure that participants will efficient and effectively comprehend answers to their questions and 
to increase their understanding and recall of information when needed. Trainers must get and retain participants' full attention to avoid them continuously multitasking, for example, being on their phones or computers. This helps to avoid stress during reflections of the training themes during the training evaluation and transfer of knowledge to work, decision-making, and creative thinking (Stone, 2008). However, trainers must also reduce multitasking during every stage of the ADDIE model as this involves intentional decisions that influence attainment of interventions' goals and objectives.

\section{Interacting with Participants}

It was vital for the trainers to interact with their target audience a few days before the actual training. This allowed time for modification of the training content to accommodate the new learning styles and profiles of participants identified during the interaction. Specifically, the trainer was able to work with participants who were illiterate and come up with strategies to help them to participate in the program. This included pairing them with those (teenagers aged 16 to 17) who were literate throughout the training. This ensured that all individuals learned the need and importance of water health. In the same vein, prompts to help participants synthesize the information that the trainer provided played a significant role in identification of individuals' behaviors or actions that increase water health problems. For example, since most of the training sessions and participants were residents of Kajiado County, who are livestock keepers, it was important to emphasize surface water contamination by animals and humans' activities such as doing laundry in the rivers. In addition, introduction to water treatment alternatives depending on the participants' needs enlightened the participants on water treatment systems and processes. 


\section{Theoretical Implications on the Program's Success}

\section{Health Belief Model}

The program evaluation results show the usefulness of water health training based on HBM. Specifically, all the HBM structures relevant to the study increased significantly after the training. These structures included participants' susceptibility, self-efficacy, and knowledge about water health, which all increased after the training interventions (Flanagan et al., 2018; Iranagh, Rahman, \& Motalebi, 2016; Smith et al., 2018). This was as a result of content section based on the recommendation of HBM. Moreover, because of the training, the participants were able to understand the severity of water-related diseases, with positive results due to the program's perceived benefits. The HBM structures relevant to the program were significantly different after the program. The training promoted effective behavior on sanitation, water treatment, safety, and quality.

HBM also postulates that interventions should match with the supporting contextual condition to increase the likelihood of adaptation of recommended behavior (Walsh, \& Morrissey, 2018). Regarding the timing of the training program, the program was conducted as an intervention to the Point of Grace Academy waterborne disease crisis that led to the closure of the existing water purification system. Thus, increasing the effectiveness of the training program.

\section{Diffusion of Innovations Theory}

The success of the training program results from understanding the target population and their aspects that determines their rate of adoption of the water purifications systems and sanitation in the programs' implementation locations through the lens of DOI. Below is a description of DOI concepts and their contributions in implementation and design phases that facilitated the program's success. 
Implementation phase. In regard to invention, many scholars view social process as a diffusion of important innovation (Rogers, 2003; Dearing \& Cox, 2018). The training program facilitated the communication of water treatment methods and how they work. It offered an opportunity to conduct a guided adaptation process through hand-on work experiences. Persuasion to adoption of new technologies and ideas happens through a two-way communication of social influence and that is embedded in social networks. In this program, the trainer connected with the opinion leaders such as church leaders (Nyaga, 2015) and student leaders (Collins, Hawk \& David, 2009) who recruited the participants. In addition, the training program also reduced anxiety and uncertainty by providing sufficient information that enhanced participants' WaterPOD operational efficacy using hands-on work.

Design. DOI provided insights on selection of strategies used to amplify innovations' visibility and observability to enhance the diffusion of water purification and sanitary measures. DOI helped in selection of participants based on their characteristics as potential adopters. This characteristic further facilitated understanding of participants' attributes that led to specification of content to suit their learning style during the design phase. In the same vein, among the potential adopters were opinion leaders to start discussions on water health good practices within their social network and act as sources of water health information. DOI provided ways that created process adaptations that increased the effectiveness of the program.

The aspects of this program, as it relates to the theoretical underpinnings, may have implications for cultures outside the western countries, DOI acknowledges the role of culture in health-related decision making of individuals and groups (Haider, Pal, \& Al-Shaura, 2005; Kibler, Ma, Hrzich, \& Roas, 2018) while the HBM does not recognize the role of culture in decision-making processes and adoption of the water health behaviors. That is, HBM does not 
account for populations whose health behaviors are made by a few but rather assumes that individuals have control over their health-related choices, despite the efforts of some researchers, like Witte and Morrison (1995) to extend HBM to include cultural considerations. In relations to the participants' profiles, $7 \%$ reported that they are responsible for their own water sources and quality while a greater percentage indicated that the government(s) is responsible for their water quality and have no control over their water. Further, opinion leaders in most schools (like Point

of Grace Academy) and communal water points (like the Oltinka well) or municipalities (like the Nairobi City Water) make decisions on water purification systems without public participation on the issues affecting their water health. Therefore, interventions that increase the efficacy and susceptibility of those with influence are important for the greater good and sustainability of the interventions.

\section{Intersection of HBM and DOI in Training}

Even though DOI mainly emphases on content development to prevent negative health behavior while DOI focuses on content presentation strategy that facilitate adoption of behavior or idea, the two theories have some intersectionality. This includes social influences/ barriers that may discourage behavior such as social support, finances and intangible results; adoption readiness; adoption processes such as hands-on work transfer of skills and knowledge that increase self-efficacy through observability; and addressing the aspect of diffusions that are accepted as trialable; and perceived benefits of the intervention.

In Africa, cultural values, norms, and practices of an extended family, clan or tribe significantly affect an individual's health (Onoh, et al., 2014; Rothmann \& Coetzee, 2005). Specifically, in the context of sexual health, individual's behavior in relation to clan or community shapes their sexual behavior and prevention and control of sexually transmitted 
diseases. Therefore, culture-centered prevention and support interventions are progressively a critical strategy to promote healthy behaviors in Africa. Further, this thesis calls for modifications of HBM and DOI and development of Afrocentric theories of health communication in Africa to promote and support healthy lifestyles and behaviors.

\section{Trainer's Contribution to the Training Success}

The ultimate goal of both DOI and HBM is to promote recommended actions and behaviors that foster wellbeing by increasing individuals' and social influences that encourage behavioral change within groups. However, these theories do not acknowledge the influence that designers'/ trainers' cultural competency has in training for change. In this thesis, the trainer's cultural familiarity and knowledge of the social context provided practical guidance in the planning, design, development, and execution of implementation strategies to facilitate implementation. This led to increase in self-efficacy, perceived susceptibility, knowledge of water contaminants and diseases through incorporation of cultural norms and practices. These findings are consistent with De Clercq (2008) who found that social norms shapes individuals' self-efficacy. Another successful contributor of this program from the trainer's perspective is the language fluency in two languages (Swahili and English) that are mainly spoken across Kenya and the Maasai tribal language, which is spoken in Kajiado County where most of the training sessions took place. The trainer was able to determine what language to use by interacting with the participants prior to the training. Therefore, the trainer and the participants understood each other culturally and linguistically, thus, reducing the existence of language barrier and miscommunication. 


\section{Findings/Training Transfer}

The findings may be generalizable to the Kenyan population since training sessions took place in four locations and the participants were from fourteen diverse counties, cities and villages.

The results also revealed that interventions that increases self-efficacy and susceptibility of those with social influence and control are important and sustainable. For example, in this thesis, most of the participants were leaders in most schools and communal water points or municipalities that make decisions on water purification systems without public participation. However, some of the training methods and strategies used may not be applicable in situations where individuals make their own choices such as safe sex promotion. In the case of safe sex promotion, the nature of culture can inform strategies used to promote condom use. For instance, in patriarchal cultures, a training program that increases men's self-efficacy and susceptibility to sexually transmitted diseases may be more successful than those that target women's efficacy.

The training program favored a more pronounced cultural landscape of collectivist approach providing room for transferability of the training methods to other African or collectivists' cultures whose decisions are made by others. Therefore, interventions that increase the efficacy and susceptibility of those in position of power are important for the greater good and sustainability of behavior change.

\section{Future Program's Changes}

Even though the training program was modified during the preparatory phase of the training, the researcher suggests addition of graphics, pictures, and training time for future training improvement. 


\section{Pictures and Graphics}

The trainer observed that participants more readily grasped concepts with more visuals throughout the training. Consequently, more graphics can enhance future trainings. Furthermore, the pictures and graphics will include vector and raster that are both professional and entertaining to facilitate learning of themes and topics presented within the program (Standing, Conezio, \& Haber, 1970). Creation of detailed handouts of themes to facilitate cues to actions for participants after the training would be of great importance, as HBM posits.

\section{Time for Training and Interaction}

The pace of this training program was average since the time was limited. More time for the training will allow detailed discussion of themes and exchange of ideas among the participants and the trainer. In addition, according to the participants' feedback on the trainer, many participants requested more time for the training and interaction.

In summary of this chapter, preparation is understanding the training content, trainer's strengths, and weaknesses and ways to enhance the transfer of skills and knowledge. This chapter explained the various training methodologies and strategies that facilitated the success of this program that other trainers can emulate and that can serve as recommendations for future training. It also provides future program changes based of the results and experiences of the trainer.

\section{Conclusion}

Overall, this thesis provides perspectives on public health and, most importantly, water health communication. Specifically, the program created awareness on how to improve sanitation and hygiene, water quality, and safe water handling practices to prevent contamination and reduce the risks of water related diseases. It helps in understanding the context of public 
health initiatives that increase the usefulness and relevance of theories of behavior change in design interventions and the role of cultural specificity in execution of the interventions. The theories, coupled with the needs assessment, informed the design and development of the intervention to increase self-efficacy and perception of the severity of water diseases and their interaction with personal and environmental determinants such as lack of exposure to water treatment messages and economic status. This thesis develops and evaluates a specific training program. It is important for public health trainers to develop effective trainings that are culturally informed to enhance and support positive health behaviors. 


\section{REFERENCES}

Agha, S. (2003). The impact of a mass media campaigns on personal risk perception, perceived self-efficacy and on other behavioral predictors. AIDS Care, 15(6), 749-762. doi:10.1080/09540120310001618603.

Aiken CS. 1987. Race as a factor in municipal under-bounding. Annual Association American Geography 77(4):564-579. doi:10.1111/j.1467-8306.1987.tb00181.x.

Akurut, M., Niwagaba, C. B., \& Willems, P. (2017). Long-term variations of water quality in the Inner Murchison Bay, Lake Victoria. Environmental Monitoring and Assessment, 189(1), 22. doi:10.1007/s10661-016-5730-4.

Alvogenors. (Creator). (n.d.). Stages of body water by age. Retrieved from https://www.alvogenors.com/media/stages_water-010.png.

Arbuckle, K. (2004). The language of pictures: Visual literacy and print materials for Adult Basic Education and Training (ABET). doi:10.1080/10228190408566228.

Archer, E., Wolfaardt, G. M., \& Van Wyk, J. H. (2017). Pharmaceutical and personal care products (PPCPs) as endocrine disrupting contaminants (EDCs) in South African surface waters. Water South Africa, 43(4), 684-706.doi:10.4314/wsa.v43i4.16

Atkinson, S., \& Cottam, B. (2011). How doctors can close the gap: Tackling the social determinants of health. Clinical Medicine, 11(1), 57-60. doi:10.1080/10550490490435777.

Awuah, E., Nyarko, K.B., Owusu, P.A., \& Osei-Bonsu, K. (2009). Small town water quality. Desalination, 248(1), 453-459. doi:10.1016/j.desal.2008.05.087. 
Baram-Tsabari, A., and B. V. Lewenstein. 2013. "An Instrument for Assessing Scientists' Written Skills in Public Communication of Science.” Science Communication,35(1): 5685. doi:10.1177/1075547012440634.

Biech, E. (2016). The art and science of training. Association for Talent Development. Retrieved from: https://books.google.com/books?hl=en\&lr=\&id=lvl-

DQAAQBAJ\&oi=fnd\&pg=PT9\&dq=The+Art+and + Science + of + Training + by + Elaine + Bi ech\&ots=rIx15eING9\&sig=71bgkynmIAF4VGgSb8JC6ewilzs\#v=onepage\&q=The\%20A rt $\% 20$ and $\% 20$ Science $\% 20$ of $\% 20$ Training $\% 20$ by $\% 20$ Elaine $\% 20$ Biech $\& \mathrm{f}=$ false

Blanton, E., Ombeki, S., Oluoch, G. O., Mwaki, A., Wannemuehler, K., \& Quick, R. (2010). Evaluation of the role of school children in the promotion of po int-of-use water treatment and handwashing in schools and households Nyanza Province, Western Kenya, 2007. The American Journal of Tropical Medicine and Hygiene, 82(4), 664-671. doi:10.4269/ajtmh.2010.09-0422.

Bornman, M. S., Aneck-Hahn, N. H., de Jager, C., Wagenaar, G. M., Bouwman, H., Barnhoorn, I. E. J., ... Heindel, J. J. (2017). Endocrine Disruptors and Health Effects in Africa: A Call for Action. Environmental Health Perspectives, 125(1), 1-10.doi:10.1289/EHP1774.

Bornman, M., Delport, R., Farías, P., Aneck-Hahn, N., Patrick, S., Millar, R. P., \& De Jager, C. (2018). Alterations in male reproductive hormones in relation to environmental DDT exposure. Environment International, 113(1), 281-289. doi:10.1016/j.envint.2017.12.039.

Borsuk, M., Rardin, L., Paul, M., \& Hampton, T. (2014). Arsenic in private wells in NH. Hanover, NH: Thayer School of Engineering at Dartmouth. Retrieved from:http://www.dartmouth.edu/ toxmetal/assets/pdf/Wellreport.pdf 
Boyer, E. W., Swistock, B. R., Clark, J., Madden, M., \& Rizzo, D. E. (2012). The impact of Marcellus gas drilling on rural drinking water supplies. Center for Rural Pennsylvania. doi:10.1111/ruso.12157.

Burke, M. J., Sarpy, S. A., Smith-Crowe, K., Chan-Serafin, S., Salvador, R. O., \& Islam, G. (2006). Relative effectiveness of worker safety and health training methods. American Journal of Public Health, 96(2), 315-324. doi:1066801495750.

Buth, J. M., Steen, P. O., Sueper, C., Blumentritt, D., Vikesland, P. J., Arnold, W. A., \& McNeill, K. (2010). Dioxin photoproducts of triclosan and its chlorinated derivatives in sediment cores. Environmental Science \& Technology, 44(12), 4545-4551.

Cantor, K. P. (1997). Drinking Water and Cancer. Cancer Causes \& Control, 8(3), 292-308. doi:10.1023/A:1018444902486.

Chaudhuri, M., Verma, S. R., \& Gupta, A. (1994). Performance evaluation of ceramic filter candles. Journal of Environmental Engineering, 120(6), 1646-1651. doi:10.1061/(asce)0733-9372(1994)120:6(1646).

Chukwuneke, F. N., Ezeonu, C. T., Onyire, B. N., \& Ezeonu, P. O. (2012). Culture and biomedical care in Africa: The influence of culture on biomedical care in a traditional African society, Nigeria, West Africa. Nigerian Journal of Medicine, 21(3), 331-333. doi: 10.2147/ahmt.s66542

Classen-Bauer, I. (Ed.). (1993). Water in Our Life: Textbook for Teachers in Environmental Education; Developed by a Group of Scientist of ITE" Internationalization and Innovation of Teacher Education”. VWB, Verlag fürWiss. Und Bildung. doi:10.1080/13664530.2012.717211. 
Connor, R., Renata, A., Ortigara, C., Koncagül, E., Uhlenbrook, S., Lamizana-Diallo, B. M., ... \& Hendry, S. (2017). The United Nations world water development report 2017. Wastewater: The untapped resource. The United Nations World Water Development Report. doi: 10.29104/wins.d.0002.2018.

Conroy, R. M., Meegan, M. E., Joyce, T., McGuigan, K., \& Barnes, J. (2001). Solar disinfection of drinking water protects against cholera in children under 6 years of age. Archives of Disease in Childhood, 85(4), 293-295. doi:10.1136/adc.85.4.293.

Crider, Y., Sultana, S., Unicomb, L., Davis, J., Luby, S. P., \& Pickering, A. J. (2018). Can you taste it? Taste detection and acceptability thresholds for chlorine residual in drinking water in Dhaka, Bangladesh. Science of the Total Environment, 613, 840-846. doi:10.1016/j.scitotenv.2017.09.135

D. Stokols, J.G. Grzywacz, S. McMahan \& K. Phillips (2003). Increasing the health promotive capacity of human environments, Journal of Health Promotion, 18(1), 4-13. doi:10.4278/0890-1171-18.1.4.

D.A. Norman (2013) The Design of Everyday Things, revised and expanded edition, Basic Books, New York, New York. doi:10.1108/07363760610655069.

Dabrowski, J. M. (2015). Development of pesticide use maps for South Africa. South African Journal of Science, 111(1-2), 07-07. doi:10.17159/sajs.2015/20140091.

Damayanti, R. (2018). Study on environmental quality and hazard identification of underground coal gasification project: A literature study and field survey. Indonesian Mining Journal, 21(2), 141-161. doi:10.30556/imj. 
Dankelman, I., \& Jansen, W. (2010). Gender, environment, and climate change: Understanding the linkages. Gender and climate change: An introduction. London: Earthscan, 21-54. doi:10.1162/glep_r_00103.

De Rochars, V. E. B., Tipret, J., Patrick, M., Jacobson, L., Barbour, K. E., Berendes, D., ... \&Roels, T. (2011). Knowledge, attitudes, and practices related to treatment and prevention of cholera, Haiti, 2010. Emerging Infectious Diseases, 17(11), 2158 doi:10.3201/eid1711.110818.

Dearing, J. W., \& Cox, J. G. (2018). Diffusion of innovations theory, principles, and practice. Health Affairs, 37(2), 183-190. doi:10.1377/hlthaff.2017.1104

Denno, D. M., Hoopes, A. J., \& Chandra-Mouli, V. (2015). Effective strategies to provide adolescent sexual and reproductive health services and to increase demand and community support. Journal of Adolescent Health, 56(1), S22-

S41.doi:10.1016/j.jadohealth.2014.09.012.

DiClemente, C. C., Schlundt, D., \& Gemmell, L. (2004). Readiness and stages of change in addiction treatment. American Journal on Addictions, 13(2), 103-119. doi.10.2105/ajph.77.7.876-a.

DiClemente, C. C., Schlundt, D., \& Gemmell, L. (2004). Readiness and stages of change in addiction treatment. American Journal on Addictions, 13(2), 103-119. doi:10.1080/10550490490435777

Doria, M. (2010). Factors influencing public perception of drinking water quality. Water policy, 12(1), 1-19. doi:10.2166/wp.2009.051 
Durst N.J. (2014). Municipal annexation and the selective under bounding of colonies in Texas' Lower Rio Grande Valley. Environmental Planning Association, 46(7),1699-1715. doi:10.1068/a130038p.

Environmental Protection Agency (2017, January 19). Private Drinking Water Wells. Retrieve from: https://www.epa.gov/privatewells.

Faour-Klingbeil, D., \& Todd, E. C. (2018). The Impact of Climate Change on Raw and Untreated Wastewater Use for Agriculture, Especially in Arid Regions: A Review. Foodborne pathogens and disease, 15(2), 61-72. doi:10.4324/9781315661605-4.

Farr, A. C., \& Ames, N. (2008). Using diffusion of innovation theory to encourage the development of a children's health collaborative: A formative evaluation. Journal of Health Communication, 13(4), 375-388.doi:10.1080/10810730802063835.

Faust, S. D., \& Aly, O. M. (1983). Chemistry of water treatment. Boston: Butterworth. doi:10.1016/b978-0-409-90000-2.50004-2

Ferron, S., Morgan, J., \&O'reilly, M. (2000). Hygiene promotion: A practical manual for relief and development. Intermediate Technology Publications. London, UK.

Fish, J., Papaloukas, P., Jaspal, R., \& Williamson, I. (2016). Equality in sexual health promotion: a systematic review of effective interventions for black and minority ethnic men who have sex with men. BMC Public Health, 16(1), 810.doi:10.1186/s12889-016-3418-x

Flanagan, S. V., Gleason, J. A., Spayd, S. E., Procopio, N. A., Rockafellow- Baldoni, M., Braman, S., ... \& Zheng, Y. (2018). Health protective behavior following required arsenic testing under the New Jersey Private Well Testing Act. International Journal of Hygiene and Environmental Health, 221(6), 929-940. doi:10.1016/j.ijheh.2018.05.008 
Foerde, K., Knowlton, B. J., \&Poldrack, R. A. (2006). Modulation of competing memory systems by distraction. Proceedings of the National Academy of Sciences, 103(31), 11778-11783. doi:10.1073/pnas.0602659103

Forsyth, A. D., \& Carey, M. P. (1998). Measuring self-efficacy in the context of HIV risk reduction: Research challenges and recommendations. Health Psychology, 17(6), 559. doi:10.1037//0278-6133.17.6.559.

Fotso, J., Ezeh, A.C., Madise, N.J., \& Ciera, J. (2007). Progress towards the child mortality millennium development goal in urban sub-Saharan Africa: they dynamics of population growth, immunization, and access to clean water. BMC Public Health, 7(1), 218. doi:10.1186/1471-2458-7-218.

Fox, M. A., Nachman, K. E., Anderson, B., Lam, J., \& Resnick, B. (2016). Meeting the public health challenge of protecting private wells: Proceedings and recommendations from an expert panel workshop. Science of the Total Environment, 554, 113-118. doi:10.1016/j.scitotenv.2016.02.128.

Franz, A. (2005). A performance study of ceramic candle filters in Kenya including tests for coliphage removal (Doctoral dissertation, Massachusetts Institute of Technology). Retrieved from: http://hdl.handle.net/1721.1/31120.

Gibson, J. M., \& Pieper, K. J. (2017). Strategies to Improve Private-Well Water Quality: A North Carolina Perspective. Environmental Health Perspectives, 125(1), 1-9 doi: 10.1289/EHP890.

Ginter, P. M., Duncan, W. J., \& Swayne, L. E. (2018). The strategic management of healthcare organizations. John Wiley \& Sons. doi:10.1097/00004010-199123000-00006. 
Glassman, J. R., Franks, H. M., Baumler, E. R., \& Coyle, K. K. (2014). Mediation analysis of an adolescent HIV/STI/pregnancy prevention intervention. Sex Education, 14(5), 497-509.

Gonsalves, G. S., Kaplan, E. H., \&Paltiel, A. D. (2015). Reducing sexual violence by increasing the supply of toilets in Khayelitsha, South Africa: a mathematical model. PLoS one, 10(4), e0122244. doi:10.1371/journal.pone.0122244.

Grandjean, A. (2004). Water requirements, impinging factors and recommended intakes. ILSI North America, Hydration: Fluids for Life. doi:10.1111/j.1753-4887.2012.00546.x.

Gustafson, K. L., \& Branch, R. M. (2002). What is instructional design? Trends and issues in instructional design and technology, 16-25. doi:10.1002/9781119207528.ch1.

Hoedjes, J. C. B. (2014) Public participation in environmental research. Occasional Paper, 22

(1) Retrieved from http://www.worldagroforestry.org/downloads/Publications/PDFS/OP14396.pdf

Holman, D., Pavlica, K., \& Thorpe, R. (1997). Rethinking Kolb's theory of experiential learning in management education: The contribution of social constructionism and activity theory. Management Learning, 28(2), 135-148. doi:10.2166/.20116.051

Hoppe, B. O., Harding, A. K., Staab, J., \& Counter, M. (2011). Private well testing in Oregon from real estate transactions: An innovative approach toward a state-based surveillance system. Public Health Reports, 126(1), 107.

Iranagh, J. A., Rahman, H. A., \& Motalebi, S. A. (2016). Health Blief Model-based intervention to improve nutritional behavior among elderly women. Nutrition Research and Practice, 10(3), 352-358. doi:10.4162/nrp.2016.10.3.352 
Kasen, S., Vaughan, R. D., \& Walter, H. J. (1992). Self-efficacy for AIDS preventive behaviors among tenth grade students. Health Education Quarterly, 19(2), 187-202. doi:10.1177/109019819201900204

Kayembe, J. M., Thevenon, F., Laffite, A., Sivalingam, P., Ngelinkoto, P., Mulaji, C. K., ... \&Poté, J. (2018). High levels of faecal contamination in drinking groundwater and recreational water due to poor sanitation, in the sub-rural neighbourhoods of Kinshasa, Democratic Republic of the Congo. International Journal of Hygiene and Environmental Health, 221(3), 400-408. doi:10.1016/j.ijheh.2018.01.003.

Kibler, J. L., Ma, M., Hrzich, J., \& Roas, R. A. (2018). Public Knowledge of Cardiovascular Risk Numbers: Contextual Factors Affecting Knowledge and Health Behavior, and the Impact of Public Health Campaigns. In Lifestyle in Heart Health and Disease, 1(1) 1120). doi:10.1186/1471-2458-14-1131

Knobeloch, L. (2009). 2008-9 Survey of Private Well Owners. Wisconsin Department of Health Services.

Kozisek, F. (2005). Health risks from drinking demineralised water. Nutrients in Drinking Water, 1(1), 148-163. doi:10.1007/978-3-319-09593-6_7.

Kumar, S., \&Preetha, G. S. (2012). Health promotion: an effective tool for global health. Indian journal of community medicine: Official publication of Indian Association of Preventive \& Social Medicine, 37(1), 5. doi:10.4103/0970-0218.94009.

Kurman, J., \& Hui, C. (2011). Promotion, Prevention or Both: Regulatory Focus and Culture Revisited. Online Readings in Psychology and Culture, 5(3). doi:10.9707/23070919.1109 
Luepker, R. V., Perry, C. L., McKinlay, S. M., Nader, P. R., Parcel, G. S., Stone, E. J., ... \&Kelder, S. H. (1996). Outcomes of a field trial to improve children's dietary patterns and physical activity: The Child and Adolescent Trial for Cardiovascular Health (CATCH). Jama, 275(10), 768-776. doi:10.1001/jama.1996.03530340032026.

Macassa, G., Ghilagaber, G., Bernhardt, E., \& Burstrom, B. (2004). Contribution of household environment factors to urban childhood mortality in Mozambique. East African medical journal, 81(8), 408-414. doi:10.4314/eamj.v81i8.9202.

Mahat, G., \&Scoloveno, M. A. (2010). HIV peer education: Relationships between adolescents' HIV/AIDS knowledge and self-efficacy. Journal of HIV/AIDS \& Social Services, 9(4), 371-384.

Major, D. C., Omojola, A., Dettinger, M., Hanson, R. T., \& Sanchez-Rodriguez, R. (2011). Climate change, water, and wastewater in cities. Climate change and cities: First assessment report of the urban climate change research network, 113-143. doi:10.1017/cbo9780511783142.011.

Metwally, A. M., Ibrahim, N. A., Saad, A., \& Abu El-Ela, M. H. (2006). Improving the roles of rural women in health and environmental issues. International Journal of Environmental Health Research, 16(2), 133-144. doi:10.1080/09603120500539208.

Minkler, M., \& Wallerstein, N. (Eds.). (2011). Community-based participatory research for health: From process to outcomes. John Wiley \& Sons. doi:10.1177/1524839909335804.

Mitch, W. A., \&Sedlak, D. L. (2002). Formation of N-nitrosodimethylamine (NDMA) from dimethylamine during chlorination. Environmental Science \& Technology, 36(4), 588595.doi: doi.org/10.1021/es010684q. 
Molenda, M. (2017). The Systems Approach to Instructional Development. In Issues in Technology, Learning, and Instructional Design (pp. 53-61). Routledge.

Morris, R. D., Audet, A. M., Angelillo, I. F., Chalmers, T. C., \&Mosteller, F. (1992).

Chlorination, chlorination by-products, and cancer: a meta-analysis. American Journal of Public Health, 82(7), 955-963. doi:10.2105/ajph.82.7.955.

Nyaga, R. G. (2016). Beyond the millennium development goals: An evaluation of the war on HIV/AIDS in Kenya (Master's thesis). Retrieved from ProQuest database (Accession No. 10165803).

Othman, Z., Ya'acob, A., Wan Mohamad, W. N. A., \&Latiff, R. A. (2018). Development of water information communication framework. International Journal of Water, 12(3), 278-286. doi: 10.1504/IJW.2018.093676.

Pampuro, A., \& Grimes, D. (2012). What Chlorine Can't Kill: Cryptosporidium and our Water Supply? Metroscape. doi: 10.1016/b978-0-12-385130-7.00006-7.

Patrick, M., Berendes, D., Murphy, J., Bertrand, F., Husain, F., \&Handzel, T. (2013). Access to safe water in rural Artibonite, Haiti 16 months after the onset of the cholera epidemic. The American Journal of Tropical Medicine and Hygiene, 89(4), 647-653. doi:10.4269/ajtmh.13-0308.

Patterton, H. G. (2013). Scoping Study and Research Strategy Development on Currently Known and Emerging Contaminants Influencing Drinking Water Quality: Report to the Water Research Commission. Pretoria: Water Research Commission.

doi:10.1016/j.watres.2009.08.023. 
Paulussen, T., Kok, G., Schaalma, H., \& Parcel, G. S. (1995). Diffusion of AIDS curricula among Dutch secondary school teachers. Health education quarterly, 22(2), 227-243. doi:10.1177/109019819502200210.

Peterson, C. (2003). Bringing ADDIE to life: Instructional design at its best. Journal of Educational Multimedia and Hypermedia, 12(3), 227-241. Retrieved from: https://www.learntechlib.org/primary/p/2074/.

Quin, A., Balfors, B., \& Kjellén, M. (2011). How to "walk the talk": The perspectives of sector staff on implementation of the rural water supply programme in Uganda. In Natural Resources Forum, 35(4), 269-282). Oxford, UK: Blackwell Publishing Ltd. doi:10.1111/j.1477-8947.2011. 01401.x

Ranganathan, M., \&Balazs, C. (2015). Water marginalization at the urban fringe: Environmental justice and urban political ecology across the North-South divide. Urban Geography, 36(3), 403-423. doi:10.1080/02723638.2015. 1005414.

Ratzan, S. C. (2001). Health literacy: Communication for the public good. Health Promotion International, 16(2), 207-214. doi:10.1093/heapro/16.2.207.

Reiser, R. A. (2017). What field did you say you were in? In R. A. Reiser \& J. V. Dempsey (Eds.), Trends and issues in instructional design and technology (4th ed., pp. 1-7). New York, NY: Pearson Education, Inc. Retrieved from https://www.jstor.org/stable/24099974.

Rogers, M., \& Rogers, M. (1998). Innovation in Australian Enterprises: Evidence from the GAPS and IBIS Database. Melbourne Institute of Applied Economic and Social Research, the University of Melbourne. Retrieve from: 
https://melbourneinstitute.unimelb.edu.au/downloads/working_paper_series/wp1998n19. pdf.

Rootman, I., \&Goodstadt, M. (Eds.). (2001). Evaluation in health promotion: Principles and perspectives (No. 92). WHO Regional Office Europe. doi:10.1093/ije/31.5.1079.

Rule, K. L., Ebbett, V. R., \&Vikesland, P. J. (2005). Formation of chloroform and chlorinated organics by free-chlorine-mediated oxidation of triclosan. Environmental Science \& Technology, 39(9), 3176-3185. doi:10.1021/es048943+.

Saade, C., Bateman, M., \& Bendahmane, D. B. (2001). The story of a successful public-private partnership in Central America: Handwashing for diarrheal disease prevention. doi:10. 109019819201900204

Schwartz, J. J., Waterman, A. B., Lemley, A. T., Wagenet, L. P., Landre, P., \& Allee, D. J. (1998). Homeowner perceptions and management of private water supplies and wastewater treatment systems. Journal of Soil and Water Conservation, 53(4), 315-319. Retrieve from: http://www.jswconline.org/content/53/4/315.full.pdf+html.

Siegel, D. M., Aten, M. J., \&Enaharo, M. (2001). Long-term effects of a middle school-and high school-based human immunodeficiency virus sexual risk prevention intervention. Archives of Pediatrics \& Adolescent Medicine, 155(10), 1117-1126. doi:10.1001/archpedi.155.10.1117

Smith, M., Wilson, M., Robertson, M., Padilla, H., Zuercher, H., Vandenberg, R., ... \& DeJoy, D. (2018). Impact of a translated disease self-management program on employee health and productivity: Six-month findings from a randomized controlled trial. International Journal of Environmental Research and Public Health, 15(5), 851. doi:10.1016/j.ijheh.2018.05.008 
Standing, L., Conezio, J., \& Haber, R. N. (1970). Perception and memory for pictures: Singletrial learning of 2500 visual stimuli. Psychonomic Science, 19(2), 73-74. doi:10.3758/BF03337426

Stone, L. (2008). Continuous partial attention not the same as multi-tasking. Business Week, 24.doi: $10.31859 / 20040329.2142$

Sukdeo, P., Pillay, S., \&Ballabh, H. (2014). Long-term deterioration of water quality of the Mvoti Estuary, KwaZulu-Natal, South Africa. Current Science (00113891), 106(5).

Sumpter, J. P., Johnson, A. C., Williams, R. J., Kortenkamp, A., \&Scholze, M. (2006). Modeling effects of mixtures of endocrine disrupting chemicals at the river catchment scale. Environmental Science \& Technology, 40(17), 5478-5489. doi:10.1021/es052554d.

Thompson, T. L., Parrott, R., \& Nussbaum, J. F. (Eds.). (2011). The Routledge handbook of health communication. Routledge. doi:10.4324/9780203846063.

Tosam, M. J., \&Mbih, R. A. (2015). Climate change, health, and sustainable development in Africa. Environment, Development and Sustainability, 17(4), 787-800. doi:10.1007/s10668-014-9575-0.

Turley, C. M., Keizer, T., Williamson, P., Gattuso, J. P., Ziveri, P., Munro, R., ... \&Huelsenbeck, M. (2016). Hot, Sour and Breathless-Ocean under Stress. Hot, Sour and BreathlessOcean under Stress. doi:10668-014-9575-0.

Valente, T. W., Watkins, S. C., Jato, M. N., Van Der Straten, A., \&Tsitsol, L. P. M. (1997). Social network associations with contraceptive use among Cameroonian women in voluntary associations. Social Science \& Medicine, 45(5), 677-687. doi:10.1016/s02779536(96)00385-1 
Van Rooijen, D.J., Biggs, T.W., Smout, I., \&Drechsel, P. (2009). Urban growth, wastewater production and use in irrigated agriculture: a comparative study of Accra, Addis Ababa and Hyderabad. Irrigation Drainage Systems, 24, 53-64. doi:10.1007/s10795-009-90893.

Villanueva, C. M., Fernandez, F., Malats, N., Grimalt, J. O., \&Kogevinas, M. (2003). Metaanalysis of studies on individual consumption of chlorinated drinking water and bladder cancer. Journal of Epidemiology \& Community Health, 57(3), 166-173.doi: s10668-0149575-0.

Von Gunten, U. (2003). Ozonation of drinking water: Part II. Disinfection and by-product formation in presence of bromide, iodide or chlorine. Water Research, 37(7), 1469-1487. doi:10.1016/s0043-1354(02)00458-x.

Walsh, J., \& Morrissey, E. (2018). Psychological principles and health behavior change: Applications to eHealth. In eHealth Research, Theory and Development (pp. 47-67). Routledge. Retrieved from; https://www.taylorfrancis.com/books/e/9781315385891

Wang, Y., Sun, M., Yang, X., \& Yuan, X. (2016). Public awareness and willingness to pay for tackling smog pollution in China: A case study. Journal of Cleaner Production, 112, 1627-1634.doi:10.1016/j.jclepro.2015.04.135

Wasonga Job, Olang’o Charles Omondi, Kioli Felix. (2014) Improving Households Knowledge and Attitude on Water, Sanitation, and Hygiene Practices through School Health Programme in Nyakach, Kisumu County in Western Kenya. Journal of Anthropology, 2014, 1. doi:10.1155/2014/958481. 
Weigel, F. K., Hazen, B. T., Cegielski, C. G., \& Hall, D. J. (2014). Diffusion of innovations and the theory of planned behavior in information systems research: A MetaAnalysis. CAIS, 34, 31. doi:10.17705/1cais.03431.

Williams, D. R., Yu, Y., Jackson, J. S., \& Anderson, N. B. (1997). Racial differences in physical and mental health: Socio-economic status, stress and discrimination. Journal of Health Psychology, 2(3), 335-351. doi:10.1177/135910539700200305.

World Health Organization. (2004). Guidelines for Drinking-water Quality (Vol. 1). World Health Organization. Geneva, Switzerland.

World Health Organization. (2004). Guidelines for drinking-water quality: Recommendations (Vol. 1). World Health Organization. doi:10.1002/9780470172971.app2.

World Health Organization. (2006). Meeting the MDG drinking water and sanitation target: the urban and rural challenge of the decade. Retrieved from http://www.who.int/water_sanitation_health/monitoring/jmpfinal.pdf.

Wrench, J. S., Johnson, D. I., \&Citera, M. (2015). Training and development: The intersection of communication and talent development in the modern workplace. Iowa: Kendal Hunt.

Wright, J. A., Yang, H., Rivett, U., \& Gundry, S. W. (2012). Public perception of drinking water safety in South Africa 2002-2009: a repeated cross-sectional study. BMC Public Health, 12(1), 556. doi:10.1186/1471-2458-12-556

Zhao, J., Song, F., Ren, S., Wang, Y., Wang, L., Liu, W., ... \&Bazzano, L. (2012). Predictors of condom use behaviors based on the Health Belief Model (HBM) among female sex workers: a cross-sectional study in Hubei Province, China. PloS one, 7(11), e49542. doi:10.1371/journal.pone.0049542. 
Zyara, A. M., Torvinen, E., Veijalainen, A. M., \&Heinonen-Tanski, H. (2016). The effect of chlorine and combined chlorine/UV treatment on coliphages in drinking water disinfection. Journal of Water and Health, 14(4), 640-649. doi:10.2166/wh.2016.144. 


\section{APPENDIX A: WATER QUALITY ANALYSIS REPORT}

Test Site Information:

Sampling site: Canal Project

Date Sample Collected: 7/11/2018

Date Completed: 9/6/2018

Testing Type: Water Batch

\section{Key Terms}

This symbol indicates testing results were above maximum limit for consumption

This symbol indicates testing results were found well below the maximum limit and cause no concern

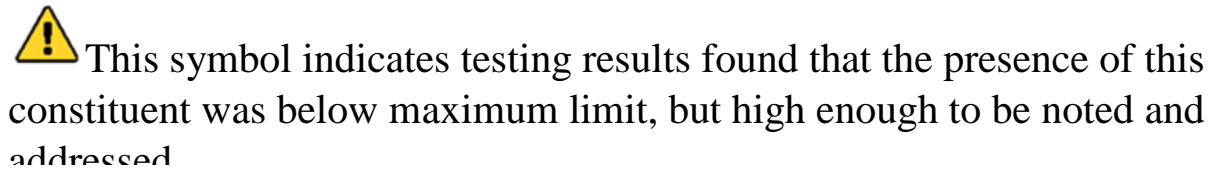

$\mathbf{M g} / \mathbf{L}$ (ppm): Results are reported as an amount in milligrams per liter known as parts per million.

The following samples have been tested by American Testing Labs and have proven the following results:

Averages of samples taken between 7/11/18 - 9/6/18 from the canal BEFORE the WaterPOD

\begin{tabular}{|l|l|l|l|l|l|}
\hline$\underline{\text { Contaminant }}$ & $\underline{\text { Maximu }}$ & $\underline{\text { Laboratory }}$ & $\underline{\text { Result }}$ & $\underline{\text { Health Concerns }}$ & Potential Source \\
$\underline{\mathbf{m}}$ & $\underline{\text { Value }}$ & & $\underline{\text { of Contamination }}$ \\
$\underline{\text { Critical }}$ & & & & & \\
Limit/or & & & & & \\
\hline
\end{tabular}




\begin{tabular}{|c|c|c|c|c|c|}
\hline \multicolumn{6}{|c|}{ Physical Factors } \\
\hline Color & -- & $\begin{array}{c}\text { Fails } \\
\text { standard }\end{array}$ & 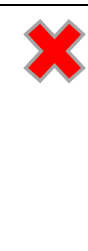 & $\begin{array}{c}\text { Dependent on } \\
\text { contaminate } \\
\text { source }\end{array}$ & $\begin{array}{l}\text { Increased levels of } \\
\text { natural deposits }\end{array}$ \\
\hline Hardness & $\begin{array}{l}\text { to } 180 \\
\text { ppm }\end{array}$ & $\begin{array}{l}333.1 \\
\mathrm{ppm}\end{array}$ & 3 & $\begin{array}{c}\text { Determination of } \\
\text { the hardness of } \\
\text { water }\end{array}$ & $\begin{array}{l}\text { Increased levels of } \\
\text { natural deposits }\end{array}$ \\
\hline Odor & -- & $\begin{array}{c}\text { Fails } \\
\text { standard }\end{array}$ & $\mathbf{x}$ & $\begin{array}{c}\text { Dependent on } \\
\text { contaminate } \\
\text { source }\end{array}$ & $\begin{array}{l}\text { Increased levels of } \\
\text { sulfur and other } \\
\text { natural deposits }\end{array}$ \\
\hline \multicolumn{6}{|c|}{ Heavy Metals } \\
\hline Aluminum & $\begin{array}{l}0.05 \text { to } 0.2 \\
\text { ppm max }\end{array}$ & $0.8 \mathrm{ppm}$ & $\mathbf{x}$ & $\begin{array}{l}\text { Dementia, loss of } \\
\text { memory, } \\
\text { circulatory } \\
\text { system issues }\end{array}$ & $\begin{array}{l}\text { Plant } \\
\text { decomposition, } \\
\text { acidified lakes }\end{array}$ \\
\hline Antimony & $\begin{array}{c}0.006 \mathrm{ppm} \\
\max \end{array}$ & 0.32 & 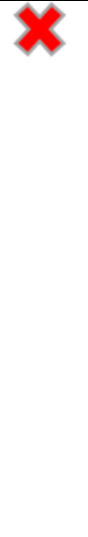 & $\begin{array}{l}\text { Increase blood } \\
\text { pressure, decrease } \\
\text { blood sugar }\end{array}$ & $\begin{array}{l}\text { Discharge from } \\
\text { petroleum } \\
\text { refineries, fire } \\
\text { retardants, } \\
\text { ceramics, } \\
\text { electronics }\end{array}$ \\
\hline Arsenic & $\begin{array}{c}0.010 \mathrm{ppm} \\
\max \end{array}$ & $0.79 \mathrm{ppm}$ & $x$ & $\begin{array}{l}\text { Skin damage, } \\
\text { circulatory }\end{array}$ & $\begin{array}{l}\text { Erosion of natural } \\
\text { deposits, runoff }\end{array}$ \\
\hline
\end{tabular}




\begin{tabular}{|c|c|c|c|c|c|}
\hline & & & & $\begin{array}{l}\text { system issues, } \\
\text { increased risk of } \\
\text { cancer }\end{array}$ & $\begin{array}{l}\text { from orchards, run } \\
\text { off from glass and } \\
\text { electronics } \\
\text { production wastes }\end{array}$ \\
\hline Barium & $\begin{array}{l}2 \mathrm{ppm} \\
\max \end{array}$ & $\begin{array}{l}0.036 \\
\text { ppm }\end{array}$ & $\sqrt{ }$ & $\begin{array}{l}\text { Increase in blood } \\
\text { pressure }\end{array}$ & $\begin{array}{l}\text { Discharge of } \\
\text { drilling wastes, } \\
\text { discharge from } \\
\text { metal refineries, } \\
\text { erosion from } \\
\text { natural deposits }\end{array}$ \\
\hline \begin{tabular}{|l|} 
Beryllium \\
\end{tabular} & $\begin{array}{c}0.004 \mathrm{ppm} \\
\max \end{array}$ & $\begin{array}{l}\text { Non- } \\
\text { Detect }\end{array}$ & $\checkmark$ & Intestinal lesions & $\begin{array}{l}\text { Discharge from } \\
\text { metal refineries } \\
\text { and coal-burning } \\
\text { factories, } \\
\text { discharge from } \\
\text { electrical } \\
\text { aerospace, defense } \\
\text { industries }\end{array}$ \\
\hline Boron & -- & $\begin{array}{l}0.004 \\
\text { ppm }\end{array}$ & $\sqrt{ }$ & $\begin{array}{l}\text { Reproductive } \\
\text { system damage }\end{array}$ & $\begin{array}{l}\text { Naturally } \\
\text { occurring element, } \\
\text { erosion of natural } \\
\text { deposits, }\end{array}$ \\
\hline
\end{tabular}




\begin{tabular}{|l|c|c|l|l|l|}
\hline & & & & & wastewater \\
leaching
\end{tabular}




\begin{tabular}{|c|c|c|c|c|c|}
\hline & & & & & $\begin{array}{l}\text { erosion of natural } \\
\text { deposits }\end{array}$ \\
\hline Cobalt & -- & $\begin{array}{l}\text { Non- } \\
\text { Detect }\end{array}$ & $\sqrt{ }$ & $\begin{array}{l}\text { Vomiting, nausea, } \\
\text { thyroid damage }\end{array}$ & $\begin{array}{l}\text { Erosion of natural } \\
\text { deposits, coal } \\
\text { mining }\end{array}$ \\
\hline Fluoride & 0 ppm max & $0.89 \mathrm{ppm}$ & $x$ & $\begin{array}{l}\text { Bone disease, } \\
\text { mottled teeth. }\end{array}$ & $\begin{array}{l}\text { Water additive that } \\
\text { promotes strong } \\
\text { teeth, erosion of } \\
\text { natural deposits, } \\
\text { discharge from } \\
\text { fertilizer and } \\
\text { aluminum } \\
\text { factories }\end{array}$ \\
\hline Iron & $\begin{array}{c}0.3 \mathrm{ppm} \\
\max \end{array}$ & $\begin{array}{l}0.367 \\
\mathrm{ppm}\end{array}$ & 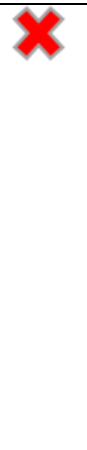 & $\begin{array}{l}\text { Contributes to } \\
\text { water hardness, } \\
\text { corrosive to } \\
\text { household } \\
\text { plumbing }\end{array}$ & $\begin{array}{l}\text { Naturally } \\
\text { occurring element, } \\
\text { erosion of natural } \\
\text { deposits }\end{array}$ \\
\hline Lead & $\begin{array}{c}0.015 \mathrm{ppm} \\
\max \end{array}$ & $0.32 \mathrm{ppm}$ & $x$ & $\begin{array}{l}\text { Delays in } \\
\text { physical or } \\
\text { mental } \\
\text { development in } \\
\text { children, defects }\end{array}$ & $\begin{array}{l}\text { Corrosion of } \\
\text { household } \\
\text { plumbing systems, } \\
\text { erosion of natural } \\
\text { deposits }\end{array}$ \\
\hline
\end{tabular}




\begin{tabular}{|c|c|c|c|c|c|}
\hline & & & & $\begin{array}{l}\text { in attention span, } \\
\text { kidney problems, } \\
\text { high blood } \\
\text { pressure }\end{array}$ & \\
\hline Lithium & -- & $\begin{array}{l}0.002 \\
\text { ppm }\end{array}$ & $\sqrt{ }$ & \begin{tabular}{|l|} 
Internal lesions \\
\end{tabular} & $\begin{array}{l}\text { Erosion of natural } \\
\text { deposits }\end{array}$ \\
\hline Magnesium & -- & $\begin{array}{l}36.82 \\
\mathrm{ppm}\end{array}$ & $\sqrt{ }$ & $\begin{array}{l}\text { Contributes to } \\
\text { water hardness, } \\
\text { corrosive to } \\
\text { household } \\
\text { plumbing }\end{array}$ & $\begin{array}{l}\text { Erosion of natural } \\
\text { deposits }\end{array}$ \\
\hline Manganese & $\begin{array}{c}0.05 \mathrm{ppm} \\
\max \end{array}$ & $\begin{array}{l}0.130 \\
\text { ppm }\end{array}$ & $x$ & -- & $\begin{array}{l}\text { Naturally } \\
\text { occurring element }\end{array}$ \\
\hline Mercury & $\begin{array}{c}0.002 \mathrm{ppm} \\
\max \end{array}$ & $\begin{array}{l}\text { Non- } \\
\text { Detect }\end{array}$ & $\sqrt{ }$ & Kidney damage & $\begin{array}{l}\text { Erosion of natural } \\
\text { deposits, discharge } \\
\text { from refineries and } \\
\text { factories, landfill } \\
\text { and crop land } \\
\text { runoff }\end{array}$ \\
\hline Nickel & -- & $\begin{array}{l}\text { Non- } \\
\text { Detect }\end{array}$ & $\sqrt{ }$ & Nausea, vomiting & $\begin{array}{l}\text { Discharge from } \\
\text { steel and metal } \\
\text { refineries }\end{array}$ \\
\hline
\end{tabular}




\begin{tabular}{|c|c|c|c|c|c|}
\hline Nitrate & $\begin{array}{l}10 \mathrm{ppm} \\
\max \end{array}$ & $\begin{array}{l}3.136 \\
\text { ppm }\end{array}$ & $\checkmark$ & $\begin{array}{l}\text { Shortness of } \\
\text { breath, blue baby } \\
\text { syndrome }\end{array}$ & $\begin{array}{l}\text { Runoff from } \\
\text { fertilizers, leaching } \\
\text { from septic tanks, } \\
\text { sewage, erosion of } \\
\text { natural deposits }\end{array}$ \\
\hline Potassium & -- & $\begin{array}{l}1.624 \\
\mathrm{ppm}\end{array}$ & $\sqrt{ }$ & $\begin{array}{l}\text { Alteration of } \\
\text { blood pressure, } \\
\text { irritation of the } \\
\text { skin }\end{array}$ & $\begin{array}{l}\text { Runoff from } \\
\text { fertilizers, } \\
\text { naturally occurring } \\
\text { element }\end{array}$ \\
\hline Selenium & $\begin{array}{c}0.05 \mathrm{ppm} \\
\max \end{array}$ & $0.3 \mathrm{ppm}$ & $x$ & $\begin{array}{l}\text { Hair or fingernail } \\
\text { loss, numbness in } \\
\text { fingers and toes, } \\
\text { circulatory issues }\end{array}$ & $\begin{array}{l}\text { Discharge from } \\
\text { petroleum and } \\
\text { metal refineries, } \\
\text { erosion of natural } \\
\text { deposits, discharge } \\
\text { from mines }\end{array}$ \\
\hline Silicon & -- & $\begin{array}{l}7.974 \\
\text { ppm }\end{array}$ & $\checkmark$ & Skin irritation & $\begin{array}{l}\text { Steel, chemical, } \\
\text { electronic } \\
\text { refineries, } \\
\text { naturally occurring } \\
\text { element }\end{array}$ \\
\hline Silver & $\begin{array}{c}0.100 \mathrm{ppm} \\
\max \end{array}$ & $\begin{array}{l}\text { Non- } \\
\text { Detect }\end{array}$ & $\sqrt{ }$ & $\begin{array}{l}\text { Dizziness, } \\
\text { vomiting, } \\
\text { diarrhea }\end{array}$ & $\begin{array}{l}\text { Naturally } \\
\text { occurring element, }\end{array}$ \\
\hline
\end{tabular}




\begin{tabular}{|c|c|c|c|c|c|}
\hline & & & & & $\begin{array}{l}\text { preservatives, } \\
\text { disinfectants }\end{array}$ \\
\hline Sodium & - & $\begin{array}{l}17.84 \\
\text { ppm }\end{array}$ & $\checkmark$ & $\begin{array}{l}\text { Increase blood } \\
\text { pressure }\end{array}$ & $\begin{array}{l}\text { Erosion of natural } \\
\text { deposits, }\end{array}$ \\
\hline Strontium & -- & $\begin{array}{l}0.058 \\
\text { ppm }\end{array}$ & $\checkmark$ & $\begin{array}{l}\text { Disrupts } \\
\text { hormonal } \\
\text { development }\end{array}$ & $\begin{array}{l}\text { Erosion of natural } \\
\text { deposits }\end{array}$ \\
\hline Titanium & -- & $\begin{array}{l}\text { Non- } \\
\text { Detect }\end{array}$ & $\sqrt{ }$ & $\begin{array}{l}\text { Nausea, vomiting, } \\
\text { skin irritation }\end{array}$ & $\begin{array}{l}\text { Naturally } \\
\text { occurring element }\end{array}$ \\
\hline Thallium & $\begin{array}{c}0.002 \mathrm{ppm} \\
\max \end{array}$ & $\begin{array}{l}0.008 \\
\text { ppm }\end{array}$ & $x$ & $\begin{array}{l}\text { Hair loss, changes } \\
\text { in blood, kidney, } \\
\text { intestine, liver } \\
\text { problems }\end{array}$ & $\begin{array}{l}\text { Leaching from } \\
\text { ore-processing } \\
\text { sites, discharge } \\
\text { from electronics, } \\
\text { glass, and drug } \\
\text { factories }\end{array}$ \\
\hline Uranium & $\begin{array}{c}0.003 \mathrm{ppm} \\
\max \end{array}$ & $\begin{array}{l}0.001 \\
\mathrm{ppm}\end{array}$ & $\sqrt{ }$ & $\begin{array}{l}\text { Increased risk of } \\
\text { cancer, kidney } \\
\text { toxicity }\end{array}$ & $\begin{array}{l}\text { Erosion of natural } \\
\text { deposits }\end{array}$ \\
\hline Vanadium & -- & $32 \mathrm{ppm}$ & $\mathbf{x}$ & $\begin{array}{l}\text { Reproductive } \\
\text { system issues }\end{array}$ & Steel additive \\
\hline Zinc & $\begin{array}{l}5 \mathrm{ppm} \\
\max \end{array}$ & $9.7 \mathrm{ppm}$ & $x$ & $\begin{array}{l}\text { Nausea, vomiting, } \\
\text { diarrhea, } \\
\text { dizziness }\end{array}$ & $\begin{array}{l}\text { Batteries, building } \\
\text { materials, naturally } \\
\text { occurring element }\end{array}$ \\
\hline
\end{tabular}




\begin{tabular}{|c|c|c|c|c|c|}
\hline \multicolumn{6}{|c|}{ Biological Factors } \\
\hline $\begin{array}{l}\text { Total } \\
\text { Coliform } \\
\text { count }\end{array}$ & $\begin{array}{c}0 \\
\mathrm{CFU} / 100 \\
\mathrm{~mL}\end{array}$ & $\begin{array}{c}276 \\
\text { CFU/100 } \\
\mathrm{mL}\end{array}$ & $\mathbf{k}$ & $\begin{array}{l}\text { Bacteria that can } \\
\text { indicate other } \\
\text { harmful bacteria } \\
\text { may be present } \\
\text { like fecal } \\
\text { coliforms and E. } \\
\text { coli }\end{array}$ & $\begin{array}{l}\text { Naturally present } \\
\text { in the environment }\end{array}$ \\
\hline $\begin{array}{l}\text { Total E. coli } \\
\text { count }\end{array}$ & $\begin{array}{c}0 \\
\text { CFU/100 } \\
\mathrm{mL}\end{array}$ & $\begin{array}{c}120 \\
\text { CFU/100 } \\
\text { mL }\end{array}$ & 3 & $\begin{array}{l}\text { Bacteria that } \\
\text { indicates fecal } \\
\text { waste, and may } \\
\text { cause diarrhea, } \\
\text { cramps, nausea, } \\
\text { headaches }\end{array}$ & $\begin{array}{l}\text { Human and animal } \\
\text { fecal waste }\end{array}$ \\
\hline
\end{tabular}




\begin{tabular}{|c|c|c|c|c|c|}
\hline \multicolumn{6}{|c|}{ Averages of samples taken from 7/11/18- 9/6/18 AFTER the WaterPOD } \\
\hline$\underline{\text { Contaminant }}$ & $\begin{array}{c}\text { Maximum } \\
\underline{\text { Critical }} \\
\text { Limit/or Goal }\end{array}$ & $\frac{\text { Laboratory }}{\text { Value }}$ & $\underline{\text { Result }}$ & $\begin{array}{c}\underline{\text { Health }} \\
\text { Concerns }\end{array}$ & $\begin{array}{c}\text { Potential } \\
\text { Source of } \\
\text { Contamination } \\
\end{array}$ \\
\hline \multicolumn{6}{|c|}{ Physical Factors } \\
\hline Color & -- & $\begin{array}{c}\text { Meets } \\
\text { standard }\end{array}$ & $\sqrt{2}$ & $\begin{array}{l}\text { Dependent on } \\
\text { contaminate } \\
\text { source }\end{array}$ & $\begin{array}{c}\text { Increased levels } \\
\text { of natural } \\
\text { deposits }\end{array}$ \\
\hline Hardness & to $180 \mathrm{ppm}$ & $331.9 \mathrm{ppm}$ & $\mathbf{x}$ & $\begin{array}{l}\text { Determination of } \\
\text { the hardness of } \\
\text { water }\end{array}$ & $\begin{array}{c}\text { Increased levels } \\
\text { of natural } \\
\text { deposits }\end{array}$ \\
\hline Odor & -- & $\begin{array}{c}\text { Meets } \\
\text { standard }\end{array}$ & $\sqrt{ }$ & $\begin{array}{l}\text { Dependent on } \\
\text { contaminate } \\
\text { source }\end{array}$ & $\begin{array}{c}\text { Increased levels } \\
\text { of sulfur and } \\
\text { other natural } \\
\text { deposits }\end{array}$ \\
\hline \multicolumn{6}{|c|}{ Heavy Metals } \\
\hline Aluminum & $\begin{array}{c}0.05 \text { to } 0.2 \mathrm{ppm} \\
\max \end{array}$ & $0.010 \mathrm{ppm}$ & $\sqrt{ }$ & $\begin{array}{l}\text { Dementia, loss } \\
\text { of memory, } \\
\text { circulatory } \\
\text { system issues }\end{array}$ & $\begin{array}{l}\text { Plant } \\
\text { decomposition, } \\
\text { acidified lakes }\end{array}$ \\
\hline Antimony & $0.006 \mathrm{ppm} \max$ & $0.002 \mathrm{ppm}$ & $\checkmark$ & $\begin{array}{l}\text { Increase blood } \\
\text { pressure, }\end{array}$ & $\begin{array}{l}\text { Discharge from } \\
\text { petroleum } \\
\text { refineries, fire }\end{array}$ \\
\hline
\end{tabular}




\begin{tabular}{|c|c|c|c|c|c|}
\hline & & & & $\begin{array}{l}\text { decrease blood } \\
\text { sugar }\end{array}$ & $\begin{array}{l}\text { retardants, } \\
\text { ceramics, } \\
\text { electronics }\end{array}$ \\
\hline Arsenic & 0 ppm max & Non-Detect & $\sqrt{ }$ & $\begin{array}{l}\text { Skin damage, } \\
\text { circulatory } \\
\text { system issues, } \\
\text { increased risk of } \\
\text { cancer }\end{array}$ & $\begin{array}{l}\text { Erosion of } \\
\text { natural deposits, } \\
\text { runoff from } \\
\text { orchards, run } \\
\text { off from glass } \\
\text { and electronics } \\
\text { production } \\
\text { wastes }\end{array}$ \\
\hline Barium & 2 ppm max & $0.037 \mathrm{ppm}$ & $\checkmark$ & $\begin{array}{l}\text { Increase in blood } \\
\text { pressure }\end{array}$ & $\begin{array}{l}\text { Discharge of } \\
\text { drilling wastes, } \\
\text { discharge from } \\
\text { metal refineries, } \\
\text { erosion from } \\
\text { natural deposits }\end{array}$ \\
\hline Beryllium & $.004 \mathrm{ppm}$ max & Non-Detect & $\sqrt{2}$ & Intestinal lesions & $\begin{array}{l}\text { Discharge from } \\
\text { metal refineries } \\
\text { and coal- } \\
\text { burning } \\
\text { factories, } \\
\text { discharge from }\end{array}$ \\
\hline
\end{tabular}




\begin{tabular}{|c|c|c|c|c|c|}
\hline & & & & & $\begin{array}{l}\text { electrical } \\
\text { aerospace, } \\
\text { defense } \\
\text { industries }\end{array}$ \\
\hline Boron & -- & $0.014 \mathrm{ppm}$ & $\checkmark$ & $\begin{array}{l}\text { Reproductive } \\
\text { system damage }\end{array}$ & $\begin{array}{l}\text { Naturally } \\
\text { occurring } \\
\text { element, } \\
\text { erosion of } \\
\text { natural deposits, } \\
\text { wastewater } \\
\text { leaching }\end{array}$ \\
\hline Cadmium & $0.005 \mathrm{ppm} \max$ & Non-Detect & $\checkmark$ & Kidney damage & $\begin{array}{l}\text { Corrosion of } \\
\text { galvanized } \\
\text { pipes, erosion } \\
\text { of natural } \\
\text { deposits, } \\
\text { discharge from } \\
\text { metal refineries, } \\
\text { runoff from } \\
\text { waste batteries } \\
\text { and paints }\end{array}$ \\
\hline Calcium & -- & $72.33 \mathrm{ppm}$ & $\sqrt{ }$ & $\begin{array}{l}\text { Development of } \\
\text { kidney stones, }\end{array}$ & $\begin{array}{l}\text { Erosion of } \\
\text { natural deposits }\end{array}$ \\
\hline
\end{tabular}




\begin{tabular}{|c|c|c|c|c|c|}
\hline & & & & $\begin{array}{l}\text { sclerosis of } \\
\text { kidneys and } \\
\text { blood vessels, }\end{array}$ & \\
\hline Chromium & $n \max$ & Non-Detect & $\sqrt{ }$ & $\begin{array}{l}\text { Allergic } \\
\text { Dermatitis }\end{array}$ & $\begin{array}{l}\text { Discharge from } \\
\text { steel and pulp } \\
\text { mills, erosion of } \\
\text { natural deposits }\end{array}$ \\
\hline Copper & $1.3 \mathrm{ppm} \max$ & Non-Detect & $\sqrt{ }$ & $\begin{array}{l}\text { Gastrointestinal } \\
\text { distress, liver or } \\
\text { kidney damage }\end{array}$ & $\begin{array}{l}\text { Corrosion of } \\
\text { household } \\
\text { plumbing } \\
\text { systems, } \\
\text { erosion of } \\
\text { natural deposits }\end{array}$ \\
\hline Cobalt & -- & Non-Detect & $\sqrt{ }$ & $\begin{array}{l}\text { Vomiting, } \\
\text { nausea, thyroid } \\
\text { damage }\end{array}$ & $\begin{array}{l}\text { Erosion of } \\
\text { natural deposits, } \\
\text { coal mining }\end{array}$ \\
\hline Fluoride & $4.0 \mathrm{ppm} \max$ & $0.357 \mathrm{ppm}$ & $\sqrt{ }$ & $\begin{array}{l}\text { Bone disease, } \\
\text { mottled teeth. }\end{array}$ & $\begin{array}{l}\text { Water additive } \\
\text { that promotes } \\
\text { strong teeth, } \\
\text { erosion of } \\
\text { natural deposits, } \\
\text { discharge from } \\
\text { fertilizer and }\end{array}$ \\
\hline
\end{tabular}




\begin{tabular}{|c|c|c|c|c|c|}
\hline & & & & & $\begin{array}{l}\text { aluminum } \\
\text { factories }\end{array}$ \\
\hline Iron & $0.3 \mathrm{ppm} \max$ & $0.316 \mathrm{ppm}$ & $\checkmark$ & $\begin{array}{l}\text { Contributes to } \\
\text { water hardness, } \\
\text { corrosive to } \\
\text { household } \\
\text { plumbing }\end{array}$ & $\begin{array}{l}\text { Naturally } \\
\text { occurring } \\
\text { element, } \\
\text { erosion of } \\
\text { natural deposits }\end{array}$ \\
\hline Lead & ppm max & Non-Detect & $\checkmark$ & $\begin{array}{l}\text { Delays in } \\
\text { physical or } \\
\text { mental } \\
\text { development in } \\
\text { children, defects } \\
\text { in attention span, } \\
\text { kidney problems, } \\
\text { high blood } \\
\text { pressure }\end{array}$ & $\begin{array}{l}\text { Corrosion of } \\
\text { household } \\
\text { plumbing } \\
\text { systems, } \\
\text { erosion of } \\
\text { natural deposits }\end{array}$ \\
\hline Lithium & -- & $0.002 \mathrm{ppm}$ & $\checkmark$ & Internal lesions & $\begin{array}{l}\text { Erosion of } \\
\text { natural deposits }\end{array}$ \\
\hline Magnesium & - & $36.66 \mathrm{ppm}$ & $\checkmark$ & $\begin{array}{l}\text { Contributes to } \\
\text { water hardness, } \\
\text { corrosive to } \\
\text { household } \\
\text { plumbing }\end{array}$ & $\begin{array}{l}\text { Erosion of } \\
\text { natural deposits }\end{array}$ \\
\hline
\end{tabular}




\begin{tabular}{|c|c|c|c|c|c|}
\hline Manganese & $0.05 \mathrm{ppm} \max$ & $0.160 \mathrm{ppm}$ & $\sqrt{ }$ & -- & $\begin{array}{l}\text { Naturally } \\
\text { occurring } \\
\text { element }\end{array}$ \\
\hline Mercury & $0.002 \mathrm{ppm} \max$ & Non-Detect & $\sqrt{ }$ & Kidney damage & $\begin{array}{l}\text { Erosion of } \\
\text { natural deposits, } \\
\text { discharge from } \\
\text { refineries and } \\
\text { factories, } \\
\text { landfill and } \\
\text { crop land run } \\
\text { off }\end{array}$ \\
\hline Nickel & -- & Non-Detect & $\checkmark$ & $\begin{array}{l}\text { Nausea, } \\
\text { vomiting }\end{array}$ & $\begin{array}{l}\text { Discharge from } \\
\text { steel and metal } \\
\text { refineries }\end{array}$ \\
\hline Nitrate & $10 \mathrm{ppm} \max$ & $3.345 \mathrm{ppm}$ & $\sqrt{3}$ & $\begin{array}{l}\text { Shortness of } \\
\text { breath, blue baby } \\
\text { syndrome }\end{array}$ & $\begin{array}{l}\text { Run off from } \\
\text { fertilizers, } \\
\text { leaching from } \\
\text { septic tanks, } \\
\text { sewage, erosion } \\
\text { of natural } \\
\text { deposits }\end{array}$ \\
\hline Potassium & -- & $1.462 \mathrm{ppm}$ & $\sqrt{ }$ & $\begin{array}{l}\text { Alteration of } \\
\text { blood pressure, }\end{array}$ & $\begin{array}{l}\text { Run off from } \\
\text { fertilizers, }\end{array}$ \\
\hline
\end{tabular}




\begin{tabular}{|c|c|c|c|c|c|}
\hline & & & & $\begin{array}{l}\text { irritation of the } \\
\text { skin }\end{array}$ & $\begin{array}{l}\text { naturally } \\
\text { occurring } \\
\text { element }\end{array}$ \\
\hline Selenium & $0.05 \mathrm{ppm} \max$ & $0.008 \mathrm{ppm}$ & $\sqrt{ }$ & $\begin{array}{l}\text { Hair or finger } \\
\text { nail loss, } \\
\text { numbness in } \\
\text { fingers and toes, } \\
\text { circulatory issues }\end{array}$ & $\begin{array}{l}\text { Discharge from } \\
\text { petroleum and } \\
\text { metal refineries, } \\
\text { erosion of } \\
\text { natural deposits, } \\
\text { discharge from } \\
\text { mines }\end{array}$ \\
\hline Silicon & -- & $7.987 \mathrm{ppm}$ & $\checkmark$ & Skin irritation & $\begin{array}{l}\text { Steel, chemical, } \\
\text { electronic } \\
\text { refineries, } \\
\text { naturally } \\
\text { occurring } \\
\text { element }\end{array}$ \\
\hline Silver & 0.100 ppm max & Non-Detect & $\checkmark$ & $\begin{array}{l}\text { Dizziness, } \\
\text { vomiting, } \\
\text { diarrhea }\end{array}$ & $\begin{array}{l}\text { Naturally } \\
\text { accruing } \\
\text { element, } \\
\text { preservatives, } \\
\text { disinfectants }\end{array}$ \\
\hline Sodium & -- & $17.38 \mathrm{ppm}$ & $\checkmark$ & $\begin{array}{l}\text { Increase blood } \\
\text { pressure }\end{array}$ & $\begin{array}{l}\text { Erosion of } \\
\text { natural deposits, }\end{array}$ \\
\hline
\end{tabular}




\begin{tabular}{|c|c|c|c|c|c|}
\hline Strontium & -- & $0.058 \mathrm{ppm}$ & $\sqrt{ }$ & $\begin{array}{l}\text { Disrupts } \\
\text { hormonal } \\
\text { development }\end{array}$ & $\begin{array}{l}\text { Erosion of } \\
\text { natural deposits }\end{array}$ \\
\hline Titanium & -- & Non-Detect & $\forall$ & $\begin{array}{l}\text { Nausea, } \\
\text { vomiting, skin } \\
\text { irritation }\end{array}$ & $\begin{array}{l}\text { Naturally } \\
\text { occurring } \\
\text { element }\end{array}$ \\
\hline Thallium & 0.002 ppm max & $0.005 \mathrm{ppm}$ & 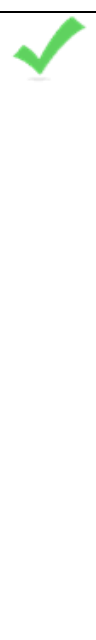 & $\begin{array}{l}\text { Hair loss, } \\
\text { changes in } \\
\text { blood, kidney, } \\
\text { intestine, liver } \\
\text { problems }\end{array}$ & $\begin{array}{l}\text { Leaching from } \\
\text { ore-processing } \\
\text { sites, discharge } \\
\text { from } \\
\text { electronics, } \\
\text { glass, and drug } \\
\text { factories }\end{array}$ \\
\hline Uranium & $0.003 \mathrm{ppm} \max$ & $0.002 \mathrm{ppm}$ & $\checkmark$ & $\begin{array}{l}\text { Increased risk of } \\
\text { cancer, kidney } \\
\text { toxicity }\end{array}$ & $\begin{array}{l}\text { Erosion of } \\
\text { natural deposits }\end{array}$ \\
\hline Vanadium & -- & $0.002 \mathrm{ppm}$ & $\checkmark$ & $\begin{array}{l}\text { Reproductive } \\
\text { system issues }\end{array}$ & Steel additive \\
\hline Zinc & 5 ppm max & Non-Detect & $\checkmark$ & $\begin{array}{l}\text { Nausea, } \\
\text { vomiting, } \\
\text { diarrhea, } \\
\text { dizziness }\end{array}$ & $\begin{array}{l}\text { Batteries, } \\
\text { building } \\
\text { materials, } \\
\text { naturally }\end{array}$ \\
\hline
\end{tabular}




\begin{tabular}{|c|c|c|c|c|c|}
\hline & & & & & $\begin{array}{l}\text { occurring } \\
\text { element }\end{array}$ \\
\hline \multicolumn{6}{|c|}{ Biological Factors } \\
\hline $\begin{array}{l}\text { Total Coliform } \\
\text { count }\end{array}$ & $0 \mathrm{CFU} / 100 \mathrm{~mL}$ & $\begin{array}{c}0 \mathrm{CFU} / 100 \\
\mathrm{~mL}\end{array}$ & $\sqrt{ }$ & $\begin{array}{l}\text { Bacteria that can } \\
\text { indicate other } \\
\text { harmful bacteria } \\
\text { may be present } \\
\text { like fecal } \\
\text { coliforms and E. } \\
\text { coli }\end{array}$ & $\begin{array}{l}\text { Naturally } \\
\text { present in the } \\
\text { environment }\end{array}$ \\
\hline $\begin{array}{l}\text { Total E. coli } \\
\text { count }\end{array}$ & $0 \mathrm{CFU} / 100 \mathrm{~mL}$ & $\begin{array}{c}0 \mathrm{CFU} / 100 \\
\mathrm{~mL}\end{array}$ & $\checkmark$ & $\begin{array}{l}\text { Bacteria that } \\
\text { indicates fecal } \\
\text { waste, and may } \\
\text { cause diarrhea, } \\
\text { cramps, nausea, } \\
\text { headaches }\end{array}$ & $\begin{array}{l}\text { Human and } \\
\text { animal fecal } \\
\text { waste }\end{array}$ \\
\hline
\end{tabular}

Test Results Approved and Verified By:

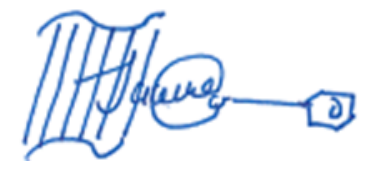

Dr. Moe Mukiibi

Chief Technology Officer and Global

Water Expert 


\section{APPENDIX B: ONLINE CONSENT FOR PROJECT}

\section{Online Consent for Project}

I am inviting you to take part in a research project. If you choose to participate, you are invited to provide feedback on the training you received today. To be eligible to participate, you must be 18 years of age or older and not currently in the European Economic Area. I ask that you please read this consent form and ask any questions you may have before agreeing to participate. Your responses will be protected and remain confidential; do not report any identifiable information in this questionnaire. The following is a brief description of the project and your rights as a research participant.

\section{Purpose of the Study:}

To assess training offered on water purification systems. This study forms part of Lavender Matuyia Ntaoti's master's thesis under the direction of Dr. John Baldwin at Illinois State University in the United States of America. The results of this research may be presented at public symposiums, published in journals, and placed on ISU's research website.

\section{Procedures and Duration of the Study:}

You are invited to take a brief questionnaire before the training and an additional questionnaire after the training. Each questionnaire will take approximately 10 minutes. We will not keep track of your computer address, making online participation anonymous. If you do not have access to a computer, you may take a hard copy of the survey, which will be confidential. Miss Ntaoti will enter the data and promptly destroy the hard-copy questionnaire.

\section{Risks and Benefits of Being in the Study:}

There are no risks for participating in this study greater than you might experience in everyday life. There are direct benefits for participating such as gaining knowledge on water health and 
use of technology.

\section{Confidentiality:}

Your participation is voluntary, and there is no penalty for not participating. Your responses will remain confidential. Do not report your name or any identification number on the research questionnaire. The records of this study will be kept private. No information that will make you identifiable will be reported. Data will be analyzed across survey with statistics. Additionally, research records will be stored securely and only the principal investigator will have access to the data.

\section{Voluntary Nature of the Study:}

Participation in this study is voluntary. Your decision whether or not to participate will not affect your current or future relations with Illinois State University. If you decide to participate, you are free not to answer questions you do not like or withdraw from the study at any time without consequences.

\section{Contacts and Questions:}

The principal investigator for this study is Dr. John Baldwin. If you have any questions regarding the study, you are encouraged to contact him on jrbaldw@ilstu.edu. If you have any questions or concerns regarding your rights as a research participant, you are encouraged to contact the Research Ethics and Compliance office at Illinois State University by phone at (309) 438-5527 or rec@ilstu.edu.

By clicking the red arrow below, you are providing your consent to participate in this research study.

You may print a copy of this consent for your records. 


\section{APPENDIX C: TIME 1 SURVEY}

\section{Source}

1. Where do you get your water from?
○ River
○ Lake
○ Municipal
○ I don't
- Dam
○ Ocean
○ Well
know

○ Other

\section{Responsibility}

2. Who is responsible for oversight of water quality in your local area?
○ Government
○ Nonprofit Organization

- Private/individuals

○ I don't know

○ Myself

3. Who takes care of water in your household? (Tick all that apply to you)
○ My wife
○ My house help
○ Parents
○ My Children
○ Someone I pay to
○ Myself
○ My husband
do so

\section{Usage}

4. What do you mostly use your water for? Choose one.
○ Domestic use
- Commercial use
- Recreational use
○ Livestock use
$\bigcirc$ Irrigation

\section{Quality}

5. Pick the quality of the water you use.
- Salty/hardness
○ Clear
○ I don't know
○ Fresh
- Gray/ brown/green 
6. Does your water have any smell?

○ Yes $\quad \circ$ No

If yes, describe the smell

\section{Other Related Challenges}

7. What are the challenges of getting this water from the source? (Tick all that apply to you)

Security

Poor sanitation

It is very far

I am unable to have time with my

family
Sometimes I miss school to get water for my family

Sometimes, I face water rationing

\section{Water Quality Information}

8. For the last one year, have you received any information about your water quality from your water provider?

○ Yes

- I never pay

○ No attention on bills

9. In the past 3 months, have you read, seen or heard anything about water quality?

○ Yes

○ No

o I don't know

10. Have you ever attended/ received any training on water health?
○ Yes
- Maybe
○ No

\section{Water Testing}

11. Do you test your water before use?

- Yes

No, why? 
12. How frequent do you test your water?

$\circ$ At least once a year

$\circ$ At least once in 2 years

$\circ$ At least once in three years
I do not test my water

I I don't see the need to

Directions: Please respond to each of the following statements based on how they relate to you, $1=$ Strongly Disagree $2=$ Disagree $3=$ Neutral $4=$ Agree $5=$ Strongly Agree

\section{a. Efficacy}

13. I am going to change my actions contribute to water pollution

14. I am willing to invest in a water treatment process

15. I support laws that protect drinking water and its sources

\section{b. Water Testing}

16. I am aware of water quality testing places

17. I pay for my water testing

18. I do lab testing for my water

19. I perform sensory testing (test done with your senses- eyes, smell, and taste)

\section{c. Susceptibility}

20. I believe that my water is NOT safe for drinking

21. I believe that my water is safe for drinking-Recoded

22. Water quality is the least of my worries Recoded

23. I believe that groundwater may not be safe to drink

24. The best place to dump waste is in the water bodies Recoded

25. Contaminated water will make me sick.

26. Have you ever thought that water from your source may not be safe for drinking? 

○ Yes
○ No
○ Maybe

\section{Contaminants Knowledge}

27. Select all water contaminants you are aware of
Pesticides
Pharmaceuticals
Bacteria and virus
Fertilizers
Lead
Human waste
Arsenic
Organics
Nitrates

\section{Waterborne Diseases Knowledge}

28. Select all water related health issues you are aware of
Cancer
Malaria
Leptospirosis
Dysentery/diarrhea
Cholera

Reproductive

health problems

\section{Water Treatment Methods}

29. What water treatment did you use to purify your water?

○ Traditional methods, specify $\quad \circ$ I do not treat my water

○ Modern methods, specify

30. How long ago did you use a water treatment method?

$\circ$ Less than 3 months $\quad \circ$ More than 12

○ 4-7 months months

○ 8-11 months $\quad$ Never

31. Do you feel like the water treatment products are expensive?
○ Yes
○ No
○ I don't know 
32. How many water treatment methods do you know?

$\circ$ None $\quad \circ \quad 1-3 \quad \circ \quad 4-6 \quad \circ \quad 7$ or more

33. Do you ever test your water before purchasing any water treatment?

Yes $\quad \square$ I do not see the $\quad \square \quad$ Not applicable

No need to

34. Do the companies or the marketers train you on how to use the treatment?

○ Yes $\quad \circ$ No

35. How willing are you to invest in a water treatment process?

$\circ$ Very willing $\quad \circ$ Somehow Willing $\quad \circ$ Not willing

$\circ$ Willing $\quad \circ$ Neutral

36. I treat my water before use because:

My neighbor is

treating his/hers

My kids taught me

how to

\section{I thought it is the}

right thing to do

I watched a water

treatment

advertisement

\section{Demographics}

37. What county do you live in?

What is your gender?

○ Male

○ Female 
38. Does anyone in your household work at a company, organization or agency whose primary business is directly related to natural resources, or water, in particular?

- Yes - Maybe

○ No

39. What is the highest level of education?

○ Primary School

○ High School

- Graduate/Professional degree

40. Please indicate your age
- Not been to school

- Masters and above 


\section{APPENDIX D: TIME 2 SURVEY}

\section{Importance}

1. What did you find most useful about today's training

\section{Knowledge of Themes}

2. How much of the content of this training did you already know?
○ All of it
- Nearly all of it
None of it
- Some of it
○ A little of it

Directions: Please respond to each of the following statements based on how they relate to you, $1=$ Strongly Disagree $2=$ Disagree $3=$ Neutral $4=$ Agree $5=$ Strongly Agree

\section{Benefits}

3. What benefit did you gain from today's training?

4. It stimulated my thinking

5. It motivated me to want to learn more on water quality

6. It motivated me to do something to improve my water health

7. I am confident that I can do something to seek safe drinking water

\section{Attitude Change}

8. I feel my attitude towards water consumption has changed as a result of this training.
- Strongly Agree
○ Neutral
○ Strongly Disagree
$\circ$ Agree
- Disagree 
Directions: Please respond to each of the following statements depending on how it relates to you $1=$ Strongly Disagree $2=$ Disagree $3=$ Neutral $4=$ Agree $5=$ Strongly Agree

\section{a. Efficacy}

9. I am going to change my actions contribute to water pollution

10. I am willing to invest in a water treatment process

11. I support laws that protect drinking water and its sources

\section{b. Water Testing}

12. I am aware of water quality testing places

13. I pay for my water testing

14. I do lab testing for my water

15. I perform sensory testing (test done with your senses- eyes, smell, and taste)

\section{c. Susceptibility}

16. I believe that my water is NOT safe for drinking

17. I believe that my water is safe for drinking-Recoded

18. Water quality is the least of my worries Recoded

19. I believe that groundwater may not be safe to drink

20. The best place to dump waste is in the water bodies Recoded

21. Contaminated water will make me sick.

22. Have you ever thought that water from your source may not be safe for drinking?

$\circ$ Yes

○ No

○ Maybe

\section{Contaminants Knowledge}

23. Select all water contaminant you are aware of
Pesticides
Fertilizers
Human waste 
$\square$ Organics $\quad \square$ Arsenic

$\square$ Pharmaceuticals $\quad \square$ Nitrates

Lead $\quad \square$ Bacteria and virus

\section{Waterborne Diseases Knowledge}

24. Select all water related health issues you are aware of

$\square$ Cancer $\quad \square$ Malaria $\quad \square \quad$ Leptospirosis

Dysentery/diarrhea $\quad \square$ Cholera

$\square$ Reproductive

health problems

\section{WaterPOD Maintenance}

25. What did you learn about the WaterPod Maintenance?

26. What did you learn about the Water purification systems and their maintenance?

27. What are some of the filter's name do you remember?

28. Do you feel this is a product you can use?

29. I feel this is a product you can adopt
○ Yes
○ No
○ Maybe

30. I feel like this product meets my needs
○ Yes
○ No
- Maybe

31. What did you not understand about the WaterPod or water health? 


\section{Improving Water Quality}

On the following reasons, state how motivated are you in improving water quality in your place $1=$ Not Motivated $2=$ Somehow Motivated $3=$ Neutral $4=$ Motivated $5=$ Very motivated

32. The impact on public health

33. The odor of bodies of water, such as ponds and lakes

34. Improved wildlife and fish habitat

35. I have had a waterborne disease.

$\begin{array}{lll}\text { Strongly Agree } & \text { Neutral } & \text { Strongly Disagree }\end{array}$

Agree Disagree

36. How many water treatment systems/methods do you know?
$\circ 0$
$\circ 1$
$\circ 2$
$\circ$ or more

\section{Cost}

37. Do you feel like the water treatment products are expensive?
$\circ$ Yes
○ No
○ I don't know

\section{Previous Training}

38. Have you ever attended/ received any training on water health?
$\circ$ Yes
○ Maybe
$\circ$ No

39. Do you think this training is important?

○ Yes

○ Maybe

○ No

Give a short description 
Would you like to rate today's trainer?

- Yes

○ No 